UNIVERSIDADE DE SÃO PAULO

ESCOLA DE COMUNICAÇÕES E ARTES

RENATO MENDES CASTANHARI

\title{
ENTRE A PINTURA E O CORPO
}

Relatos e reflexões sobre uma prática artística

São Paulo 


\section{ENTRE A PINTURA E O CORPO}

Relatos e reflexões sobre uma prática artística

Dissertação apresentada ao Programa de Pós-graduação em Artes da Escola de Comunicações e Artes da Universidade de São Paulo, para a obtenção do Título de Mestre em Artes Visuais.

Área de Concentração: Poéticas Visuais

Orientador: Prof. Dr. Geraldo de Souza Dias 
Autorizo a reprodução e divulgação total ou parcial deste trabalho, por qualquer meio convencional ou eletrônico, para fins de estudo e pesquisa, desde que citada a fonte.

Catalogação na Publicação

Serviço de Biblioteca e Documentação

Escola de Comunicações e Artes da Universidade de São Paulo

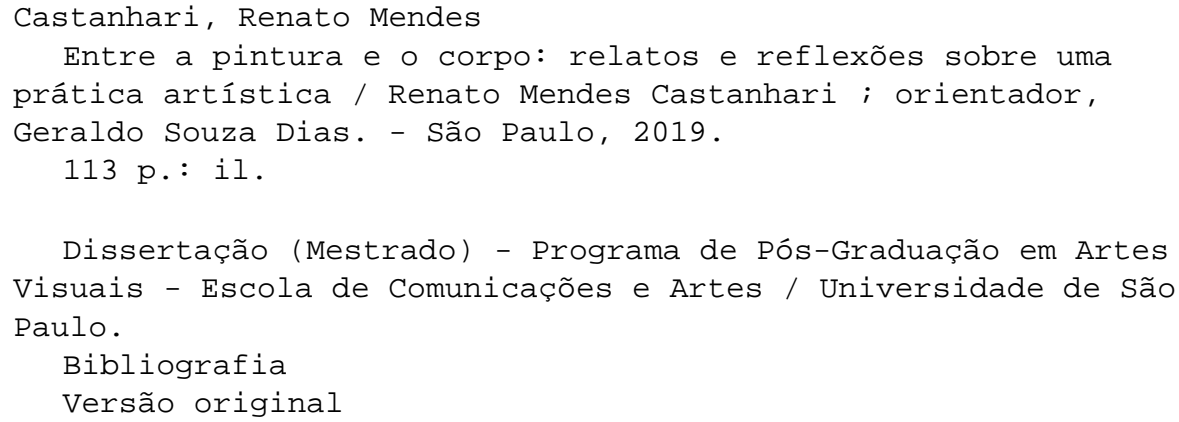


CASTANHARI, Renato M. Entre a pintura e o corpo: relatos e reflexões sobre uma prática artística. Dissertação apresentada à Escola de Comunicações e Artes da Universidade de São Paulo, para a obtenção do título de Mestre em Artes Visuais.

\section{Banca Examinadora}

Prof. Dr.

Instituição:

Assinatura:

Prof. Dr.

Instituição:

Assinatura:

Prof. Dr.

Instituição:

Assinatura:

Aprovado em: 


\section{Agradecimentos}

Ao meu orientador, Prof. Dr. Geraldo de Souza Dias, por compartilhar toda a sua experiência, pelos importantes conselhos, apoio, confiança e amizade ao longo de todo este processo. Aos professores Tiago Mesquita e Danillo Villa, pela disponibilidade e valiosas contribuições no momento da banca de qualificação. À Mariana Cobuci Schimidt Bastos pela cuidada revisão. Aos meus queridos amigos, Caio Guedes e Felipe Seixas. Aos meus pais, Nelson Castanhari e Maria de Fátima Mendes Castanhari pelo incentivo e apoio incondicionais. E em especial à minha companheira, Giuliana Nucci Carpoviki, por ser a pessoa central desse momento, pelo seu amor, cumplicidade, ajuda e enorme carinho. 


\section{Resumo}

Esta dissertação é um exercício de reflexão sobre a prática artística desenvolvida por mim nos últimos anos. O objetivo é compreender aspectos espaciais, materiais e corpóreos ligados às obras por meio da investigação das sombras, luzes, transparências e dos reflexos que as constituem. Os trabalhos estão organizados em um memorial dividido nas seguintes partes: Sombra e Luz, em que comento as primeiras obras e impressões da cidade de Berlim; Espaço e Matéria, que trata das obras realizadas de 2016 até 2019; e Reflexos do Corpóreo, no qual discorro a respeito de pinturas, objetos, performances e instalações recentes.

Palavras-chave: artes visuais; pintura; sombra; luz; espaço; matéria; reflexo; corpóreo. 


\begin{abstract}
This master thesis is an experiment in reflection about my artistic practice developed in recent years. The aim is to understand spatial, material and corporeal aspects related to the works from the investigation of the shadows, lights, reflections and transparencies that constitute them. The works are organized in a memorial divided in the following chapters: Shadow and Light, where I comment the first works and impressions of the city of Berlin, Space and Matter, that deals with the works made from 2016 until 2018 and Body Reflections, in which I discuss recent paintings, objects, performances and installations.
\end{abstract}

Keywords: visual arts; painting; shadow; light, space; matter; reflex; corporeal. 


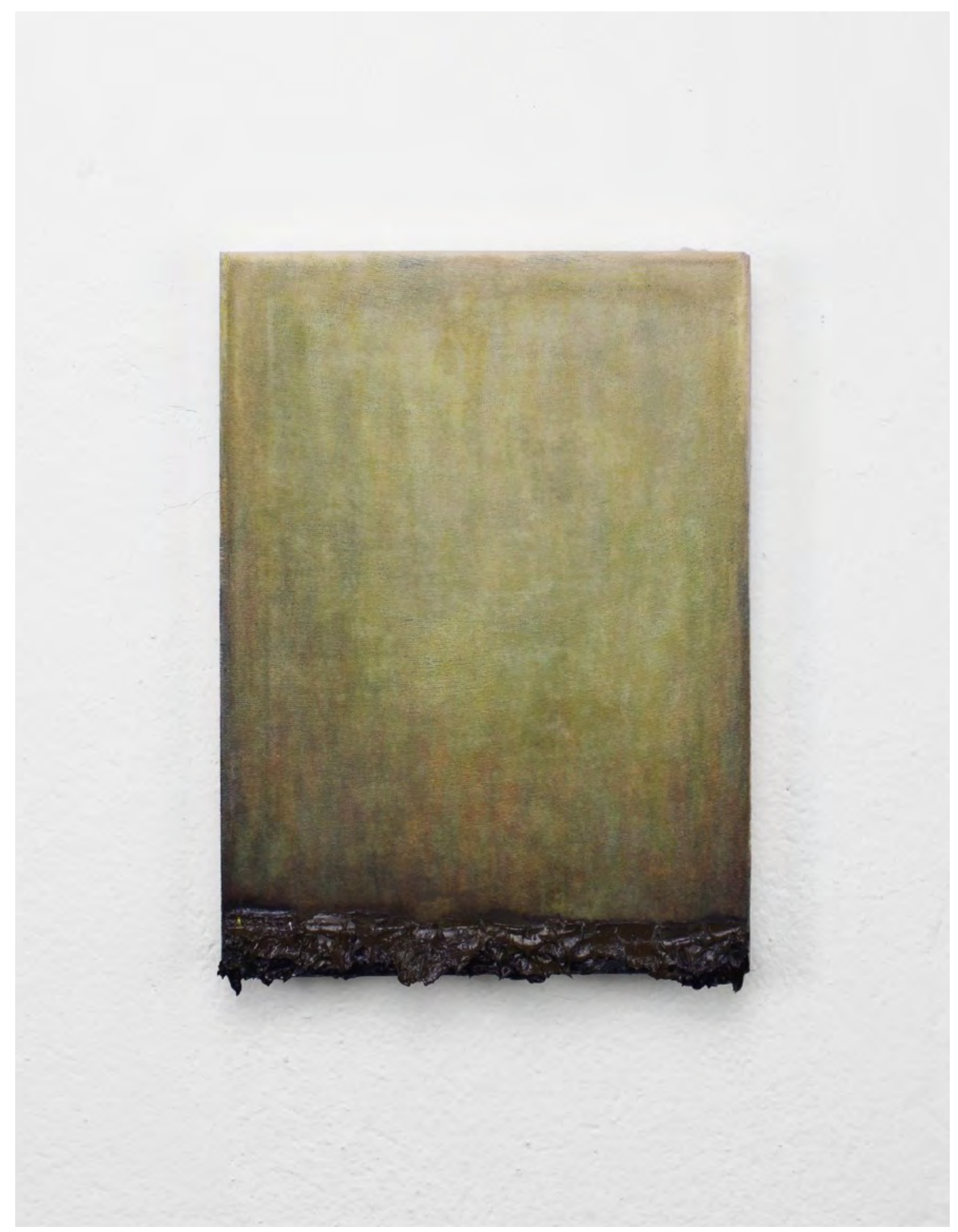

Sombras acumuladas, 2019

Óleo sobre tela

$14 \times 10 \mathrm{~cm}$ 
SUMÁRIO

Introdução ..........................................................................................................................................9

I. SOMBRA E LUZ .....................................................................................................................11

II. ESPAÇO E MATÉRIA …..................................................................................................32

III. REFLEXOS DO CORPÓREO..............................................................................45

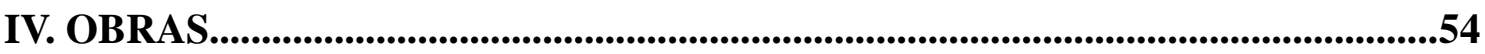

Considerações finais...................................................................................................................110

Referências....................................................................................................................111 


\section{Introdução}

Mais do que apenas consolidar um discurso sobre a prática artística, o Programa de Pós-graduação na área de Poéticas Visuais me proporcionou a oportunidade de aproximação com o trabalho de arte, estabelecendo maior sintonia e afinidade entre o fazer e o refletir.

Sobretudo, o Programa foi um dos motivos para continuar avançando com o trabalho; atenuando, assim, a ansiedade e as dúvidas que me acompanhavam na rotina do ateliê (“o que fazer?”, “o que pintar?”, “com quais materiais e linguagens devo trabalhar?").

Trago um trecho do prefácio da obra Objeto Ansioso (2004), escrito pelo crítico de arte norte-americano Harold Rosenberg (1906-1978), que aponta para as angústias e incertezas particulares ao fazer artístico: "A originalidade é uma consequência da duração da ação, da longa experiência de suportar a ansiedade e persistir. No decorrer do enfrentamento, forja-se um espírito. Fora isso, toda espécie de excelência pode ser copiada"1. Assim, um dos desafios prementes é aprender a lidar com toda a infinitude de possibilidades disponíveis no interior do ateliê, compelindo-nos, afinal, a definir caminhos a seguir.

No entanto, esses caminhos levam a questões aparentemente ambíguas, silenciosas e herméticas: qual o sentido e a urgência em investigar sombras, luzes, reflexos e matérias, quando nos deparamos todos os dias com uma realidade social e cotidiana tão severa, que parece não deixar espaço para hesitações e comedimentos?

A resposta talvez esteja em, exatamente, gerar uma experiência que é mais compenetrada do que aquela de todos os dias, que se lança em assuntos, em último exame, menos imediatistas e mais reflexivos, relacionados com as condições particulares do indivíduo: sua percepção das coisas e do próprio corpo. Sendo assim, não é possível, de saída, extrair dessas obras temas prontamente reconhecíveis: elas têm um tom de voz baixo, e vão ocupando, sem pressa e sem empurrões, as fendas que ainda restam na percepção de quem as olha. Não há, portanto, nenhuma ação impactante ou

\footnotetext{
${ }^{1}$ ROSENBERG, Harold. Objeto ansioso. São Paulo: Cosac Naify, 2004, p. 24.
} 
audaciosa que se distingue com ênfase do mundo: as operações são sempre simples e discretas. Um certo silêncio se impõe.

Este texto é um exercício de reflexão acerca do trabalho. O método foi organizar as obras em uma cronologia crítica que incluísse a descrição dos procedimentos que levaram às obras, além da discussão de referências artísticas e teóricas em torno de três eixos centrais: Sombra e Luz (parte I), Espaço e Matéria (parte II) e Reflexos do Corpóreo (parte III), identificando e pontuando uma trajetória que vai desde o seu início, com as pinturas de 2011 e 2012 feitas durante a graduação em Artes Plásticas na Universidade de São Paulo, até alcançar a exposição realizada no EdA (Espaço das Artes $)^{2}$, em simultâneo com a conclusão desta dissertação, trazendo, assim, um abrangente recorte dos trabalhos realizados ao longo desses anos.

O objetivo era que fosse possível, por meio da investigação do modo como se formam as sombras, luzes e reflexos, compreender aspectos espaciais, materiais e corpóreos ligados aos trabalhos.

Na primeira parte, Sombra e Luz, são apresentadas as obras iniciais realizadas durante a graduação. Nela, narro o processo de feitura de cada uma e escrevo a respeito das questões relacionadas à constituição da sombra e da luz. Trago também um relato da minha experiência vivida na cidade de Berlim durante o ano de 2015, a partir das impressões luminosas daquele lugar. Ao final, comento trabalhos feitos ao voltar ao Brasil em 2016, além de outros de 2017 e 2018.

Na sequência, em Espaço e Matéria, trato, principalmente, das obras realizadas de 2016 até 2019. Nesse momento, abordo pinturas, esculturas e instalações chamando a atenção para suas qualidades mais materiais. Também comento sobre a ideia desses trabalhos operarem nas bordas do objeto: extrapolando um certo lugar determinado em direção ao espaço circundante.

Por fim, a terceira parte: Reflexos do Corpóreo, na qual trago performances, pinturas, instalações e projetos mais recentes. Nela é explorado um sentido de corporeidade que permeia a produção, em trabalhos onde surgem indícios de um corpo representado de maneira fragmentada e reflexiva.

\footnotetext{
2 Antiga sede do MAC-USP na Cidade Universitária.
} 
I. SOMBRA E LUZ

Acender uma vela

é lançar uma sombra

Ursula Kroeber Le Guin, O Feiticeiro e a Sombra 
Por algum tempo, no início dessa prática artística, considerei que a cor era aquilo que essencialmente buscava, mas, conforme essa cor se dissipava ao longo das telas realizadas, até chegar em certos trabalhos feitos quase que exclusivamente com tinta branca ou preta, ficou claro que conceber algum sentido de sombra e luz era o que mais interessava. A cor, então, seria um dos meios para estabelecer relações entre regiões luminosas e escuras no plano da pintura (fig. 5).

E não se tratava, tão somente, como poderia sugerir, da aplicação de uma técnica de claro-escuro $^{3}$ no sentido de utilizar sombras e luzes exclusivamente enquanto veículos para a construção das formas. Isso eventualmente acontecia; contudo, a intenção principal era defini-las como entidades autodeterminadas, providas de materialidades e sentidos próprios. Por conta dessa autonomia almejada foi possível pensar nas sombras e luzes na qualidade de realidades independentes.

O historiador romeno Victor Stoichita (1999), ao comentar uma fotografia realizada por Constantine Brancusi (imagem a seguir) que retratava sua própria obra, $O$ Começo do Mundo (1920), nos revela de que modo a forma do ovo nasce do conflito estabelecido entre sombra e luz na imagem fotográfica:

A escultura, um grande ovo de mármore, repousa sobre uma superfície polida e é iluminada por um feixe de luz [...]. O fundo, por detrás da escultura, reflete a fonte de luz sob a forma de um grande semicírculo que ocupa toda a parte superior da imagem. Quanto ao ovo, apresenta uma metade iluminada e outra metade na sombra. Toda parte inferior da imagem é preenchida por um reflexo inteiramente sombrio.

[Brancusi] concebe a sua representação como uma encenação da metafísica do Gênesis, em que a forma simbólica do início - o ovo - surge miraculosamente do conflito entre sombra e luz. Mas este conflito, tão bem transmitido pela distribuição quase geométrica do claro-escuro, encarado como verdadeira força que "cria" o volume da escultura, vai um pouco além do que seria absolutamente necessário. ${ }^{4}$

3 Expressão com origem na palavra italiana chiaroscuro para "luz e sombra" ou "claro-escuro". O chiaroscuro é também um termo que define o uso de contrastes marcantes entre luz e sombra que formam e modelam a imagem.

${ }^{4}$ STOICHITA, Victor. Breve história da sombra. Trad. Rui Pires Cabral. Lisboa: KKYM, 2016. p. 199. 


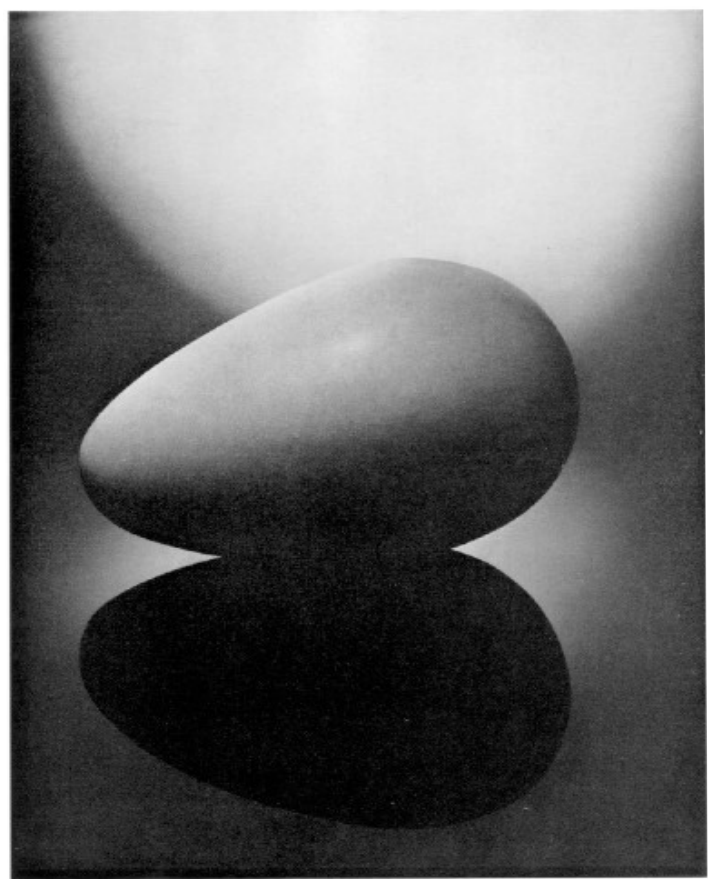

Constantin Brancusi, O Começo do Mundo, 1920 Fotografia

$A$ fotografia de Brancusi talvez sirva aqui enquanto modelo acabado do potencial autossuficiente que a sombra e a luz podem incorporar em uma composição. Na imagem são as geradoras da forma do ovo, mas são também emancipadas dela: "vão além do necessário", respondendo a suas próprias particularidades, tendo tanto peso e matéria quanto o ovo de mármore polido.

Nos meus trabalhos, principalmente nesse recorte inicial, não há essa relação tão marcada e definitiva, as formas às vezes são instáveis e imprecisas; em certas pinturas pode haver gradações tonais lentas entre as partes mais claras e escuras. Com isso, a autonomia e a presença marcadas das sombras e luzes se tornam um tanto ambíguas, como, por exemplo, em pinturas onde há sobreposições de camadas transparentes de cor (fig. 19).

Voltamos, então, à cor. Apesar de iniciar procurando retirar o seu protagonismo, não é possível negar sua importância para esses trabalhos, já que é por intermédio dela que as sombras e luzes ganham suas qualidades mais distintas. 


\section{Pinturas, 2011-2012}

A minha prática artística começa em 2010, no curso de Artes Plásticas da Universidade de São Paulo, quando inicio um trabalho de pintura ligado, em um primeiro momento, a questões de composição e cor que pretendia investigar.

Considero o conjunto de quatro pinturas de 2011 (figs. 1-4) como as obras iniciais. Foi quando trabalhei pela primeira vez em tela (até aquele momento tinha apenas utilizado tinta sobre papel) e pude perceber a textura mais presente da trama do tecido em relação à fibra do papel a qual estava habituado. Nessa época, ao participar de disciplinas voltadas à pintura, tomei maior contato com essa linguagem e iniciei algumas experimentações.

Olhando com o distanciamento de alguns anos, percebo nesses primeiros trabalhos um lugar ainda muito indeterminado de formas dispersas, como massas de cores derramadas pela superfície da pintura, representando, talvez, reflexos em um espelho d'água remexido. A paleta é de cores rebaixadas: são marrons, rosas, laranjas e verdes misturados, sem muitos matizes puros. A intenção era conceber (com algum grau de complexidade) regiões de maior predomínio de luz ou sombra.

Posteriormente, resolvo aumentar a escala e reduzir os elementos e cores da composição (figs. 5 e 6). Surge a forma do retângulo - motivo desenvolvido nos trabalhos seguintes - , uma espécie de reflexo interno das bordas da própria tela, que, nesses trabalhos, tem também um sentido de janela por onde a luz externa atravessa e invade um espaço interior de sombras sugerido pelas laterais escuras.

No ano de 2012, volto a fazer trabalhos em papel. Diferente da pintura em tela, onde costumo calcular e planejar mais as ações, no papel tenho um maior desprendimento, e por isso consigo mais velocidade e agilidade para resolver a pintura. Talvez pelo vazio do papel assumir um sentido diferente daquele da tela: "O branco do papel é mais generoso que o da tela. Sua mudez é eloquente"5.

Esses novos trabalhos em papel (figs. 7-12) têm uma superfície de cores uniformes e formas simplificadas, sem tantas nuances ou misturas de elementos e matizes como naquelas observadas nas primeiras pinturas. Neles, os gestos do pincel

\footnotetext{
5 TASSINARI, Alberto. Quatro esboços de leitura. Posfácio. Em: MERLEAU-PONTY, Maurice. $O$ olho e o espírito. Trad. Paulo Neves Maria Ermantina. São Paulo: Martins Fontes, 1999, p. 145.
} 
ficaram também mais destacados: podemos enxergar na superfície do papel as marcas das cerdas.

Ao mesmo tempo em que realizava os trabalhos de caráter mais abstrato, participei de aulas de modelo vivo, nas quais, pela primeira vez, utilizei tinta óleo (figs. 13 e 14). Com suas cores mais fulgurantes e um tempo de secagem mais prolongado em relação à acrílica, o óleo me permitiu novas possibilidades. Esse primeiro contato com a tinta ficou restrito aos exercícios de aula, somente mais tarde iria utilizá-la com mais regularidade.

Na segunda metade de 2012, continuei a desenvolver a série com as pinturas de retângulos (figs. 16-22), agora com telas maiores, de 100 x $70 \mathrm{~cm}$. Esses trabalhos se davam, principalmente, pela utilização de cores de pouca saturação, sempre misturadas com tintas brancas e pretas. Quando mais matizada, a cor sempre estava por detrás de camadas acinzentadas que suprimiam parte da sua energia cromática (fig. 21).

Essa série de pinturas é definida por composições nas quais sempre há uma região de cor central acompanhada de uma borda fina contrastando com esse centro dominante (fig. 18), sugerindo, assim como nas obras de 2011 (figs. 5 e 6), a imagem de uma janela. Porém, dessa vez, trata-se de uma janela mais opaca, menos translúcida, estabelecida a partir de veladuras, dando a sensação de que a luz está retida na superfície da tela.

Para mais, as gamas de cores cinzas, azuis e violetas dessas pinturas remetem a uma imagem com as cores invertidas - iguais àquelas que vemos em um negativo fotográfico contra a luz —, criando uma certa duplicidade de sentido que possibilita imaginar áreas escuras como luminosas e vice-versa. Temos ainda os escorridos de tinta deixados nas telas (figs. 18, 20, 21 e 22) enquanto marcas que podem evidenciar a própria tinta e a orientação vertical na qual essas pinturas foram feitas.

Em 2013, faço uma pequena pausa nos trabalhos de pintura. Esse foi o último ano no Departamento de Artes Visuais, sendo também o ano em que estava mais envolvido com trabalhos no campo da performance ${ }^{6}$. Apesar dessa breve interrupção, ainda produzi algumas pinturas que seriam o ponto de partida para uma nova série surgida em 2014 (figs. 23 e 24).

\footnotetext{
6 Abordarei esses trabalhos de performance na terceira parte deste texto: Reflexos do corpóreo.
} 


\section{DSC01199, 2012}

Ainda em 2012, realizei um trabalho com fotografias digitais chamado DSC01199 (figs. 25-28). O título dessa obra, que significa Digital Still Camera, faz referência ao prefixo e à numeração atribuídos automaticamente para nomear as imagens registradas por uma câmera digital da Nikon utilizada na série. A intenção foi destacar — além de reforçar — um certo caráter impessoal dessas imagens que não fazem referência a algo facilmente reconhecível. São, na verdade, fotos da tela ligada de um monitor de computador em que é possível enxergar a malha de pixels que a forma. Essas imagens foram feitas para serem vistas exclusivamente de um monitor de computador ou de uma superfície emissora de luz.

O processo dessa série consistia em fotografar a tela do monitor, onde era exibida uma imagem completamente branca. Em seguida, essa imagem era reinserida no computador para ser exibida na tela e novamente fotografada. Esse processo se repetiu por algumas sessões, e dele, devido à refração da luz dos pixels causada pelo vidro do monitor e da lente da câmera, surgiram imagens de faixas de cores que seguiam a ordem do espectro visível, iguais à sequência de cores vistas em um arco-íris.

O fato de essas imagens terem sido feitas muito próximas à tela do monitor (a objetiva era posicionada a uma distância de aproximadamente cinco centímetros da superfície do monitor, expondo a câmera a uma quantidade excessiva de luz emitida por ele) fez ser necessário o uso de uma abertura muito pequena do diafragma da câmera. Esse procedimento de diminuir o diafragma ao seu tamanho mínimo acarretou no escurecimento das bordas das imagens, principalmente nas suas regiões superiores.

A correlação entre sombras nas laterais e luz central estabelecida nas imagens dessa série é muito próxima daquela das pinturas maiores de 2011 (figs. 5 e 6). Deste modo, uma certa concepção de luz-sombra pretendida na pintura, por meio de pigmentos, parece também acontecer em um outro meio que se vale, como na fotografia e no monitor iluminado, diretamente da luz enquanto meio. 


\section{Pinturas figurativas, 2014}

No ano de 2014 retomo a pintura com mais fôlego, trabalho com maior regularidade e começo a desenvolver uma nova investigação com imagens mais figurativas (figs. 32-40), rompendo com os retângulos na vertical. Assuntos relacionados a pedras, paredes e grades aparecem, e pela primeira vez pinto paisagens - motivo que perdura por todo o ano e me possibilita pensar a tela na horizontal, em um campo mais expandido em relação à posição vertical anterior.

Para as duas pinturas de grades (figs. 32 e 33) usei como modelo imagens sem autoria encontradas na internet através de buscas por termos como "grades coloniais" ou "grade antiga para janela".

A primeira (fig. 32) é uma grade amarela encostada em um muro branco desgastado. Muro que pode ser também compreendido como um espaço vazio onde a grade só se equilibra de pé à frente de um horizonte desabitado. A cor amarela das linhas que compõem a grade - construídas por meio de pinceladas contínuas feitas à mão livre - é somada aos consertos e retoques realizados entre elas e o muro, gerando misturas de tinta que produzem tons de cinza esverdeado ao redor das barras. Por isso, há a impressão de que a armação de ferro vibra e se dilui no muro.

A pintura Sem título, 2014 (fig. 33), retrata outra grade, dessa vez já instalada em uma janela vista do lado de fora de uma construção (possivelmente uma pequena casa). O procedimento de pintura é muito próximo daquele realizado no trabalho anterior são também pinceladas livres que em alguns momentos se fundem através das barras —, mas, nessa obra, devido a estrutura da grade ter sido pintada com uma tinta verdeescura e preta, sua presença é mais marcante, distinguindo-a claramente das demais áreas, conferindo-lhe, por isso, peso na composição.

Essa é uma janela de natureza diferente - e mesmo oposta - daquelas discutidas nos trabalhos anteriores. Primeiro porque é de fato uma janela pintada: não se refere à sugestão da ideia de janela a partir de formas retangulares como nas outras pinturas, tornando mais evidente e explícita a representação da janela. E segundo porque não se trata de um interior onde a luz externa entra, mas sim um exterior onde observamos de fora o seu interior sombreado. 
O sentido infundido pelas grades escolhidas para esses dois trabalhos diz respeito à possibilidade de ver através delas ao mesmo tempo em que somos restringidos a acessar diretamente esse lugar com nossos corpos, emoldurando um determinado espaço no interior da obra que só é alcançado por uma projeção do olhar.

Nas pinturas seguintes (figs. 34-37) vemos paisagens de montanhas em tons de cinza, azul e verde (figs. 34-36), e uma vista mais urbana de um prédio (fig. 37). A duas primeiras (fig. 34) são pinturas feitas com base em uma fotografia realizada no ano de 2012, em uma viagem que realizei à África do Sul (imagem a seguir). Assim como $B A S F, 2014$ (fig. 37), que utiliza de modelo uma foto tirada durante minha primeira visita à Berlim, em 2013.

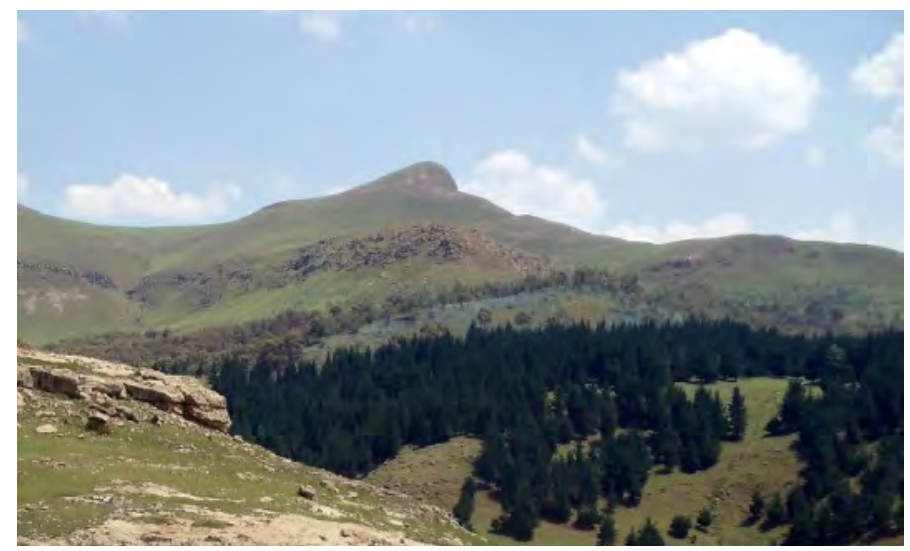

Paisagem África do Sul, 2012.

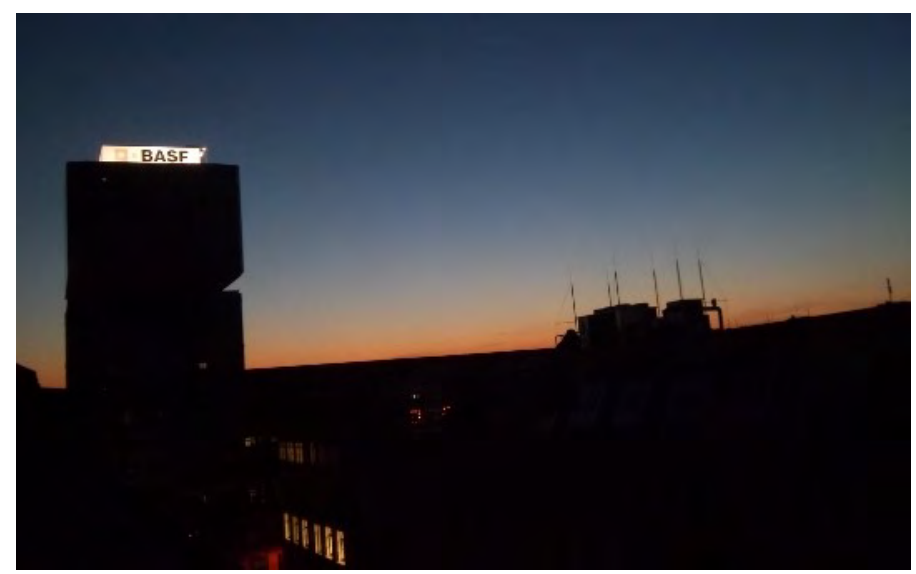

Basf, Berlim, 2013. 
Essas fotos tiveram suas cores e contrastes invertidos em um software de tratamento de imagens antes que fossem utilizadas como modelos para as pinturas. Assim, a natureza da luz e das sombras foi inteiramente modificada. Na pintura BASF é como se ela tivesse sido pintada a partir do negativo fotográfico da imagem modelo.

Com a consolidação da fotografia digital, o filme fotográfico virou um artefato restrito àqueles mais interessados e imersos no meio. Por essa razão, pintar a imagem com suas cores invertidas, além das consequências em relação às propriedades luminosas, nos faz pensar a respeito de alguma particularidade que se perdeu desse meio ligada ao filme fotográfico, convertendo essas pinturas em lembranças de uma qualidade analógica perdida.

Caco, 2014 (fig. 38), é a pintura de uma lasca de ardósia. Seu formato alongado e pontiagudo nos faz imaginar um instrumento de corte rudimentar, tornando a pintura uma espécie de registro arqueológico em negativo de uma ferramenta primitiva encontrada. Em negativo porque se vale do mesmo procedimento de inversão cromática da imagem matriz descrita nas pinturas anteriores.

Há algumas particularidades a serem destacadas: o ângulo aqui é frontal e a escala é de um para um. Não se trata de uma paisagem e sim de um objeto sem profundidade de campo. Vale dizer também que, para esse trabalho, foi utilizado um scanner na captura da imagem da pedra no lugar de uma câmera. Tudo isso faz a pintura parecer um fotograma ${ }^{7}$, revelando propriedades óticas peculiares, diferentes daquelas observadas em imagens feitas por intermédio da câmera fotográfica, nas quais os pormenores de uma superfície são realçados.

As três últimas obras de 2014 são, novamente, paisagens realizadas com base em imagens com cores manipuladas, sendo uma pintura sobre papel (fig. 36) e duas sobre tela (figs. 41 e 42). Diferente das demais, essas pinturas mostram paisagens mais achatadas e sem detalhamentos, com características mais gráficas.

A pintura Sem título, 2014 (fig. 42), tem um sentido muito próximo das anteriores (figs. 36 e 41). Contudo, foi feita na vertical, restringindo a área da paisagem, e teve o seu assunto duplicado. Logo, observamos uma paisagem dobrada, que ocupa dois terços da tela, seguida por uma área escura na sua parte superior. Há, porém,

\footnotetext{
${ }^{7}$ Técnica de registro através de exposição direta à luz sem a utilização de uma câmera. Geralmente realizada a partir da justaposição de objetos variados sobre um papel sensível à luz.
} 
diferenças nos valores tonais das cores que tornam cada uma das paisagens um negativo da outra: o azul da paisagem da base é menos luminoso do que o cinza do céu que a compõe, e na paisagem superior é o contrário. Essa elaboração de uma paisagem duplicada se repetiria, com algumas diferenças, em trabalhos de 2016 (figs. 47-49).

Grande parte desses trabalhos mais figurativos é realizada por meio de uma paleta de cores um tanto "pálidas", dando a sensação de essas vistas serem de lugares desabitados, onde não há mais a presença humana. Nessas pinturas fica aparente a influência do pintor italiano Giorgio Morandi (1890-1964). Suas naturezas-mortas, valendo-se de uma paleta econômica e suave, parecem buscar a substância primeira das coisas. O pintor paulista Paulo Pasta (2012) faz um comentário nessa mesma direção: “O mundo, em suas pinturas, o mundo físico e carnal, parece ter ido embora para poder sobrar algo do durável do mundo" . Há aqui uma proximidade de sentido: parece que também Morandi buscava por meio da cor alcançar um lugar onde só pudesse residir o essencial das coisas.

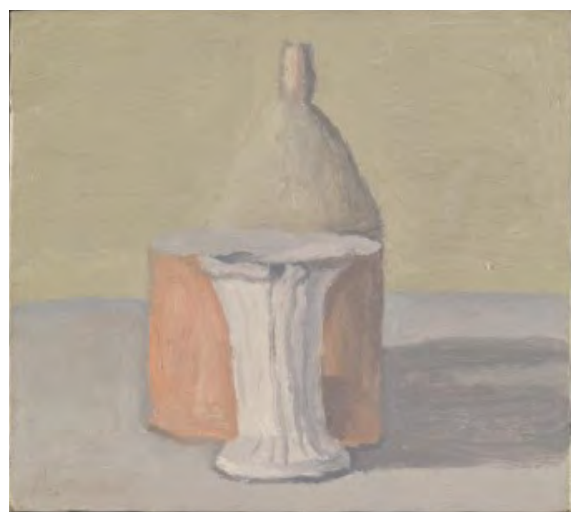

Giorgio Morandi, Natura morta, 1960, óleo sobre tela, $24,8 \times 28 \mathrm{~cm}$

\section{Berlim, 2015}

O ano de 2015 foi muito importante para o trabalho, já que foi quando morei em Berlim. Não tanto pelo volume de obras realizadas, pois não tive as condições materiais mais adequadas, mas sim por ter sido um momento de grandes descobertas e

\footnotetext{
8 PASTA, Paulo. Educação pela pintura, Martins Fontes, São Paulo, 2012. p. 107.
} 
crescimento pessoal. Berlim é uma cidade com uma vida cultural intensa que me proporcionou experiências fundamentais para o meu desenvolvimento artístico.

Apesar das dificuldades em achar um espaço adequado para o ateliê e conseguir os materiais, ainda encontrei alguns meios para trabalhar. As obras desse período mostram o aprofundamento na pesquisa da cor e no interesse de forjar sombras e luzes frias e transparentes (figs. 43-47).

A vontade por uma luz indireta e fria na pintura (já talvez presente em obras anteriores) é intensificada com a experiência luminosa que tive durante, principalmente, o inverno de Berlim. Nessa estação, a luz solar parece modelar o espaço de maneira mais suave. Quando a cidade estava coberta de neve, um certo tom azulado predominava em toda a atmosfera e superfícies (imagem a seguir).

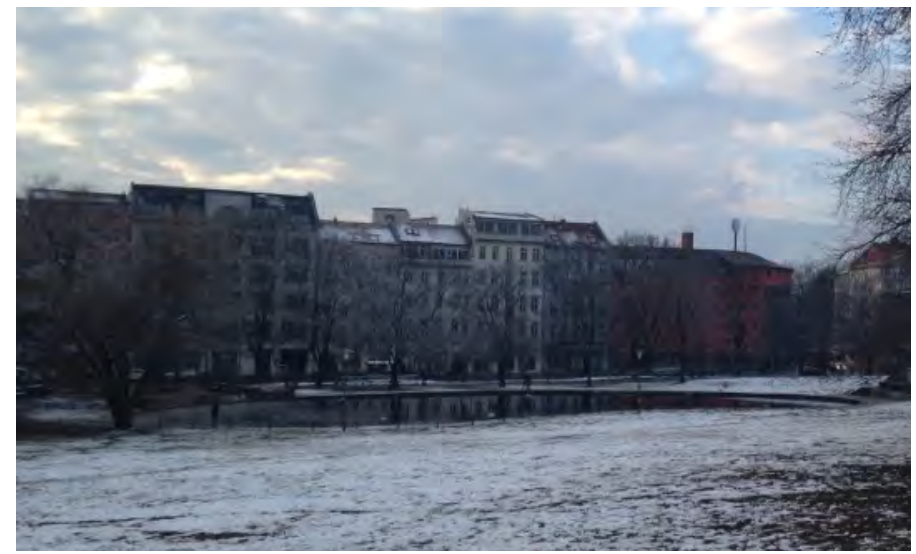

Weinbergspark, Berlim, Alemanha, 2015

$\mathrm{Na}$ arquitetura dos prédios de tijolos marrons, havia um leve sombreado que envolvia todas as fachadas. Nas empenas cegas malcuidadas e esmaecidas dos prédios dos bairros mais periféricos de Berlim (imagem a seguir), sempre era possível observar pichações ou cartazes colados. Todo esse ruído e imperfeição chamaram minha atenção, parecia que, nessas superfícies aparentemente abandonadas, havia indícios de uma cidade que só existia enquanto ruína. 


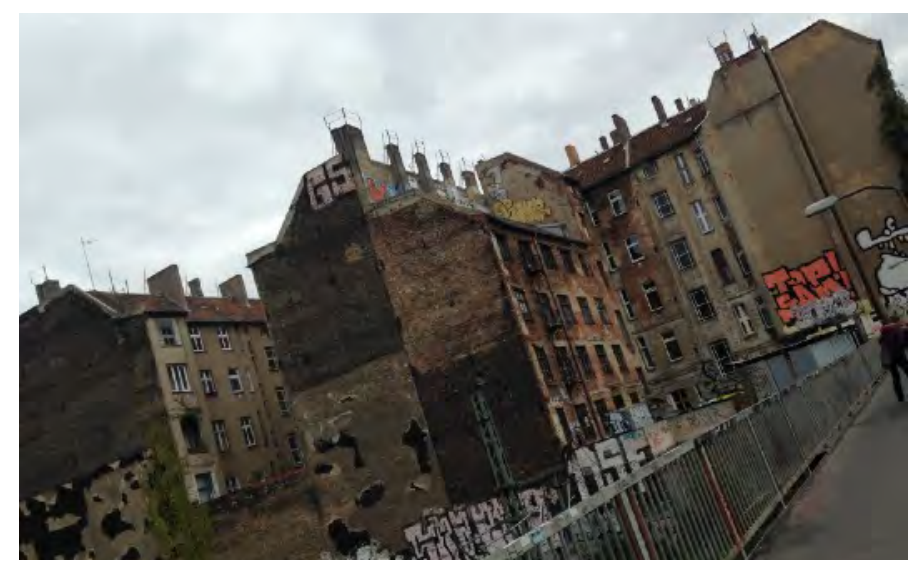

Kreuzberg, Berlim, Alemanha, 2015

O conjunto de três pequenas pinturas de 2015 (fig. 43) representa o esforço de articular camadas transparentes e sobrepostas de cores para estabelecer essas luzes e sombras mais "geladas". As marcas do pincel são aparentes, ajudando a enxergar e assimilar os movimentos empregados para conceber essas pinturas. Em todas elas, há finas bordas que funcionam como molduras precárias de um arranjo que é também instável.

Na obra Sem título, 2015 (fig. 44), camadas diluídas de tinta preta cobrem parcialmente áreas de cores mais saturadas, tal como o vermelho próximo à base ou o marrom-claro que está por detrás desse cinza esverdeado. Mas nem todo o espaço da pintura foi coberto com tinta, é possível enxergar ainda partes da tela branca original, principalmente nas bordas. Aqui, parece haver menção a essas superfícies de alvenaria esmaecidas descritas acima, em que a pintura procura emular suas impressões de sombra e luz.

Sem título, 2015 (fig. 45), vai pelo mesmo caminho e é ainda mais sombria. O cinza aplicado em cima do verde-claro e do azul-escuro é muito diluído e deixa marcas de escorrimento por toda a tela. Essa pintura lembra uma superfície coberta por uma matéria escura de fuligem, proveniente de um ambiente exposto à poluição contínua, que acaba por esconder as suas cores e formas originais.

Há também uma nova Berlim que nasce após a queda do muro, composta por prédios envidraçados de arquitetura contemporânea onde a luz flui livremente através da translucidez desse material. Uma parte desses prédios é governamental, como o conjunto arquitetônico da chancelaria. O símbolo mais proeminente dessa nova 
arquitetura é o domo de vidro do parlamento reformado, projetado pelo arquiteto Norman Foster em 1999 (imagem a seguir).

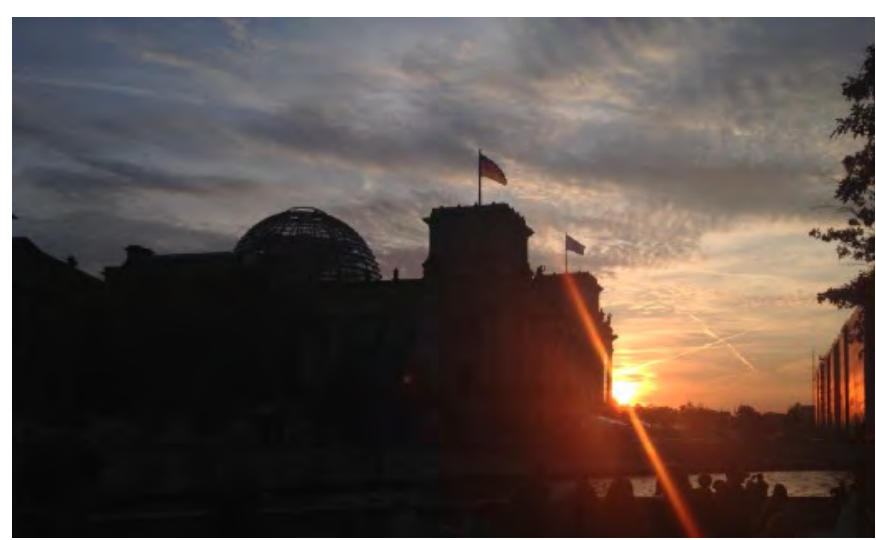

Parlamento, Berlim, Alemanha, 2015

Outro marco arquitetônico importante nessa experiência mais translúcida com a cidade, um pouco mais antigo (anterior à queda do muro), é a Neue Nationalgalerie, projetada e construída em 1968 por Mies Van der Rohe (imagem a seguir). Próxima ao Tiergarten, um dos maiores parques da cidade, com suas estruturas de ferro aparente e completamente revestida por vidro, seu prédio parece não ter peso, como se flutuasse.

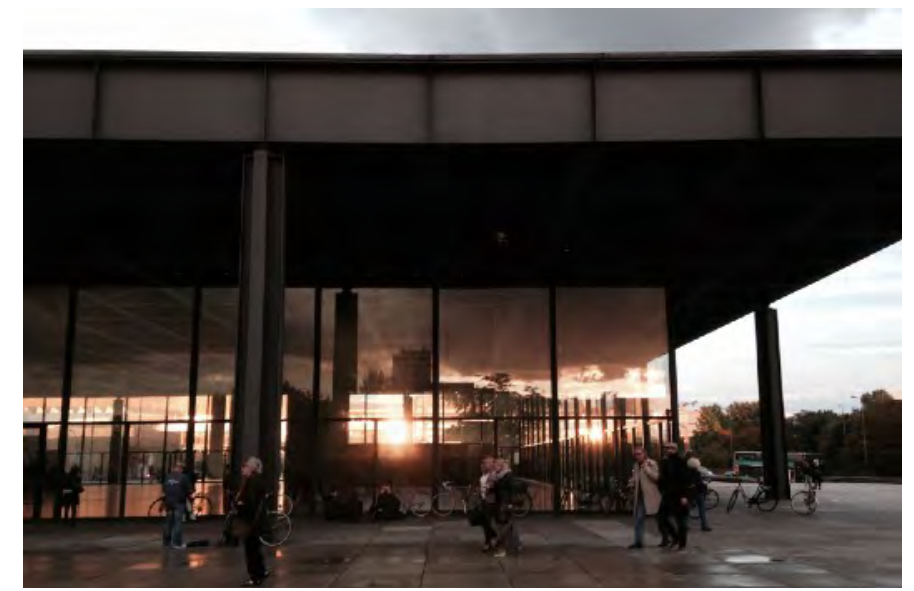

Neue Nationalgalerie, Berlim, 2015.

Essa outra faceta de Berlim, mais iluminada, transparente e plena de luz, foi marcante no trabalho, mas não tanto de imediato. Noto maiores ecos nas obras mais 
recentes da mostra Apagamento $^{9}$, 2017, em que busco tornar a pintura um objeto transparente, revelando suas estruturas e elementos (figs. 79 e 82).

Um pintor de referência pelo o seu trato com a luz e que se aproxima desse sentido é o californiano John Zurier. Esse artista consegue, valendo-se de uma apurada economia de recursos, elaborar um despojado espaço pictórico de uma luminosidade constante (imagem a seguir). O próprio Zurier reconhece que não se trata de uma tarefa simples: "Eu queria que a pintura fosse preenchida com um pálido céu vazio. Eu pensei que seria muito fácil fazer isso, mas percebi que era algo quase impossível" 10 .

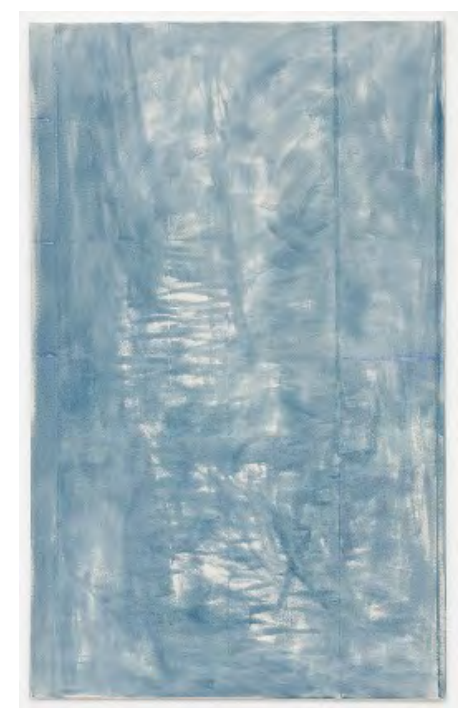

John Zurier, A spring a thousand years ago, 2012, óleo sobre tela, $183 \times 111 \mathrm{~cm}$

\section{Pinturas 2016}

No final de 2015 retorno ao Brasil e percebo uma mudança nas pinturas: surge um colorido mais desinibido. Algumas obras trazem nas camadas superiores laranjas e azuis sem muita mistura (figs. 53, 54 e 58), como se agora a cor tentasse emergir dos cinzas predominantes nos trabalhos iniciais.

\footnotetext{
9 Apagamento (2017): exposição realizada entre julho e setembro de 2017 na galeria Sancovsky em São Paulo durante a minha participação no Programa de Pós-gradução em Artes Visuais (PPGAV) da ECA/ USP.

10 Tradução do autor. Disponível em: http://www.johnzurier.com/about1.html. Acesso em: 25 ago. 2016. Original: "I wanted the painting to be filled with a pale empty sky. I thought it would be very easy to do, but found it nearly impossible".
} 
A cor mais saturada funciona aqui enquanto uma luminescência de natureza artificial, como se fossem lançados feixes ultravioletas sobre uma superfície escura, gasta e opaca, e algumas partes dela reagissem e relampejassem de volta, revelando formas e cores que estariam escondidas sob outras fontes de luz (figs. 52, 56 e 58). Assim, essas pinturas parecem mencionar técnicas que utilizam luzes como raios $X \mathrm{e}$ ultravioletas (frequências do espectro que não enxergamos) para trazer à tona cores perdidas em obras antigas, algo como uma investigação arqueológica feita através de luzes que não vemos.

Outro ponto importante para a constituição das sombras e luzes nessas pinturas está relacionado ao modo como algumas dessas obras são feitas: a partir de magras camadas opacas que se sobrepõem ao longo das sessões de trabalho; a tinta a óleo diluída em excesso no solvente faz com que toda a sua viscosidade e brilho característicos deem lugar a uma tinta rala e líquida. Com isso, as finas pinceladas aparentes se convertem em uma luz de qualidade bem particular, quase uma "luz negativa".

Um contraponto possível seria a luz do artista venezuelano Armando Reverón (1889-1954), um pintor que conseguiu sintetizar a luz solar em tinta sobre tela. Em algumas de suas pinturas do litoral de Macuto, na Venezuela, Reverón capta a saturação máxima da luz tropical por meio de manchas de pigmento branco que se transformam em luz plena (imagem a seguir ${ }^{11}$ ). Por isso, a luz de alguns dos meus trabalhos seria uma espécie de negativo dessa luz plena de Reverón (fig. 49).

Luiz Pérez-Oramas, conterrâneo de Reverón e curador convidado da $24^{\mathrm{a}}$ Bienal de São Paulo (1998), empenha-se na pesquisa desse artista. Em uma entrevista à Folha de S.Paulo, em janeiro de 1998, comentou: "Reverón bebeu a luz equatorial e a devolveu como paisagens, numa antropofagia da luz"12.

\footnotetext{
11 Tive a oportunidade, em fevereiro de 2016, de ver pessoalmente uma dessas paisagens exposta na Pinacoteca do Estado de São Paulo durante a mostra Paisagem nas Américas: pinturas da Terra do Fogo ao Ártico.

12 Reportagem da Folha de S. Paulo realizada em 27 de janeiro de 1998. Disponível em: http:// www1.folha.uol.com.br/fsp/ilustrad/fq270111.htm
} 


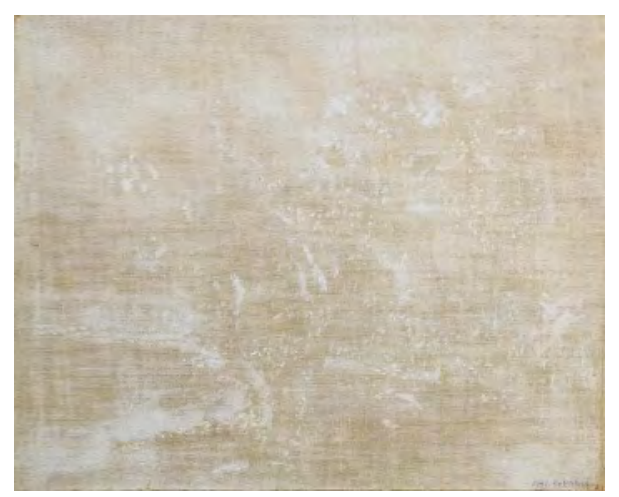

Armando Reverón, El Arbol, 1931, óleo sobre tela, 64,5 x 80,6 cm

Já em outros trabalhos, percebemos uma superfície de aspecto gasto e áspero (figs. 59, 60, 62, 63 e 64), sugerindo a face de um muro sujo e envelhecido pela ação de intempéries, que é, em certas obras, coberta parcialmente por uma camada nova de tinta (figs. 59, 63 e 64).

A superfície "gasta" é feita — mais uma vez — a partir de uma tinta tão diluída em solvente que o pigmento perde todo o óleo (seu veículo), e, ao invés de criar um filme homogêneo, acaba de esfarelando e se acumulando nas tramas da tela. A tinta perde também toda propriedade luminosa e aparência plástica do óleo, dando à pintura um aspecto empoeirado e sem vigor. Isso resulta, de fato, em uma superfície pictórica tão frágil que o pigmento fica disperso, e muitas vezes se solta da tela apenas pelo manuseio da pintura.

Esse procedimento acaba por encenar na superfície uma temporalidade passada, de um plano em ruínas, que esmoreceu (fig. 63). Daí, parece gerar sombreados e luzes "envelhecidas". Quando, então, uma camada uniforme de cor é aplicada parcialmente com uma espátula sobre ela (figs. 54 e 64), essas pinturas ganham um certo frescor e sentido de obra ainda em andamento: como se a pintura estivesse na eminência de ser terminada. É possível fazer uma analogia com um muro que, passado certo tempo, precisa de uma demão de tinta renovada que cobrirá os ruídos e detritos acumulados com a passagem do tempo, um processo que pode repetir-se ad infinitum.

Essas evocações de ruína e tempo distante não são consequências apenas das articulações entre sombra e luz, na verdade, a cor sem presença afirmativa também é crucial para definir esses sentidos. É como se esses trabalhos buscassem seus 
significados em uma espécie de substrato arqueológico da matéria, como se a erosão causada pela passagem do tempo pudesse revelar uma essência remota.

Também nas paisagens pintadas pelo artista paulista Lucas Arruda é possível verificar paralelos com a constituição de luzes e sombras de uma natureza passada. Arruda cria com cores suaves um espaço de luz crepuscular ao mesmo tempo em que afirma a fisicalidade da tinta ao acumular matéria pictórica nas extremidades da tela. Trata-se de um procedimento que busca cavoucar essa matéria até que uma paisagem ideal se torne visível no corpo da pintura, quase como um fóssil encontrado que contém uma vista primitiva. Por isso, parece haver nos trabalhos dele uma vontade de sedimentar uma origem em um tempo longínquo (imagem a seguir ${ }^{13}$ ).

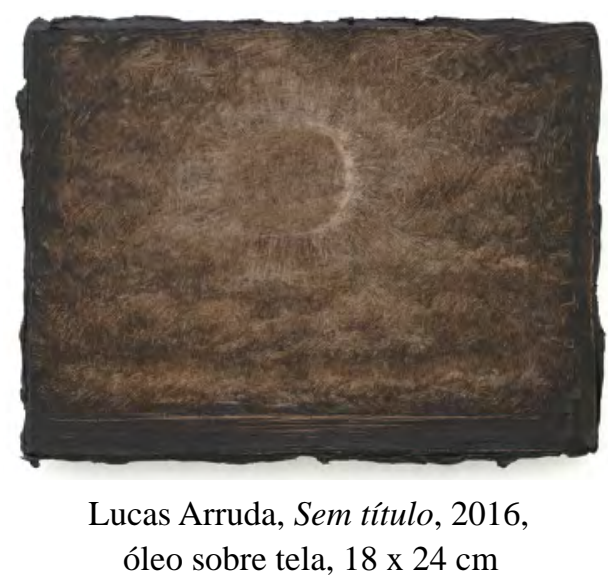

\section{Sombras e Luzes pintadas, 2017}

As três obras seguintes compõem a exposição Apagamento. Diferente de todas as apresentadas anteriormente, essas são, além de pinturas, objetos de caráter instalativo que operam na parede do espaço onde estão colocadas, valendo-se de pinturas feitas ao seu redor para simular sombras ou áreas de luz.

Sombra pintada, 2017 (fig. 83), é uma ripa de madeira de 100 x 15 x $5 \mathrm{~cm}$ presa à parede e acompanhada de uma pintura cinza à direita que simula a projeção de uma sombra cortada na diagonal. Nesse trabalho, a pintura cinza na parede acaba se

\footnotetext{
${ }^{13}$ Estive na mostra individual do artista em 2016 na galeria Mendes Wood DM. Nela, Arruda expõe essa pintura separada das demais em um dos corredores da galeria e utiliza um spot de iluminação que ficava exatamente focado na pintura, produzindo a sensação de que a luz emanava diretamente da tela.
} 
misturando com as sombras reais projetadas em volta da peça, jogando com a presença física dessas sombras, de coisas que estão e não estão lá.

Esse processo de criar sombras que parecem projetadas de um dado objeto pode remeter aos trabalhos da artista gaúcha Regina Silveira. Porém, no caso dela, a sombra é gráfica e de alto contraste, deixando evidente seu sentido artificial. Na imagem abaixo, referente à obra $A$ Lição de 2002, as sombras reais, que vemos no chão, são irrelevantes para o trabalho quando comparadas com as formas pretas. Já Sombra pintada é uma operação mais discreta, que pode até passar desapercebida (por isso houve a necessidade de indicar o procedimento no nome da obra). Diferente de A Lição, o intuito de Sombra pintada é a participação direta das sombras reais projetadas, chamando nossa atenção para tudo aquilo que envolve a peça de madeira.

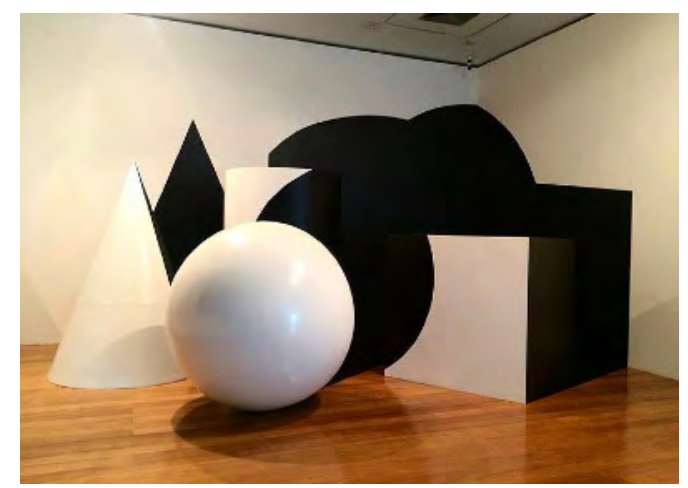

Regina Silveira, A Lição, 2002,

madeira, vinil e pintura automotiva

A ideia de alto contraste está mais presente na obra Luz pintada, 2017 (fig. 78). Essa pintura é realizada tanto na tela, com tinta acrílica preta, quanto na parede, logo abaixo do seu suporte, com acrílica branca. Para melhor compreender o trabalho é essencial explicar dois procedimentos feitos no espaço: o primeiro foi pintar todas as paredes da galeria na cor cinza-claro; com isso, foi possível usar a tinta branca diretamente na parede para compor um campo específico próximo ao suporte da pintura. O outro foi desligar a lâmpada do teto que iluminava essa obra (fig. 97), deixando-a na penumbra, removendo ainda mais luz da sua superfície já pintada com tinta preta fosca. Assim, a obra funciona segundo um jogo de luzes, sombras e tinta que é, ao mesmo tempo, próprio à tela da pintura e à parede à sua volta. 
Vale ainda dizer que a tinta usada na tela é uma tinta de parede comum, que não é um material artístico por definição. O seu modo de aplicação também não é usual: ao invés de utilizar um pincel, a superfície da tela foi mergulhada em uma espécie de pequena piscina, e na sequência ficou pendurada para que o excesso escorresse, resultando em uma pintura completamente homogênea e lisa (imagem a seguir).

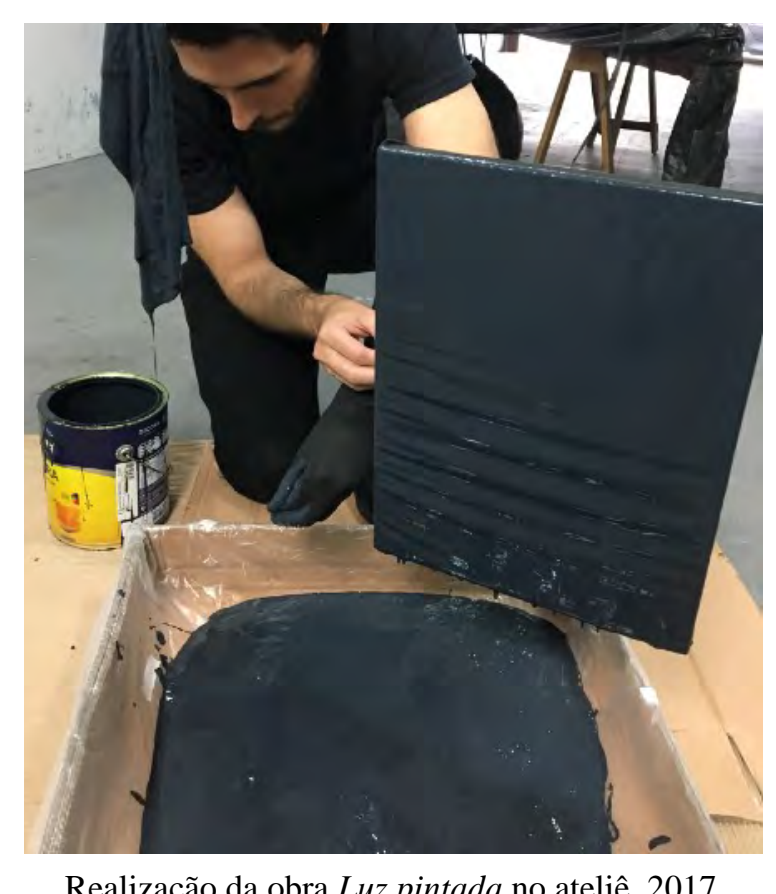

Já Sem título, 2017 (fig. 82), é uma tela coberta por um tecido de lycra muito fino, que permite enxergar seu interior, revelando suas estruturas e morfologia internas: o chassi de madeira e a própria parede do espaço. Nessa obra foi aplicada uma base acrílica transparente da sua metade para baixo. Dessa forma, a pintura acontece de fato na parede logo atrás da tela (que foi pintada de tinta branca), fazendo com que o trabalho "gere" uma luminosidade vinda de dentro para fora.

\section{Paisagem Fantasma, 2018}

Concluo esta primeira parte comentando a pequena pintura de 14 x $10 \mathrm{~cm}$ chamada Paisagem Fantasma, 2018 (fig. 86). Feita também de um tecido de lycra crua, que torna possível ver através da superfície, nela foi utilizada uma técnica de 
encáustica $^{14}$ no lugar da tinta óleo: uma mistura de cera de abelha derretida com terebintina e pigmento.

Empregando apenas pigmento branco, vemos na base da tela manchas que lembram nuvens desfazendo-se em um céu. Mais espessas e concentradas próximas ao canto inferior da tela, essas manchas brancas se diluem e desaparecem logo acima, tal como uma matéria movediça e instável que muda seu estado físico e evapora.

Esses atributos que descrevem as manchas enquanto uma matéria inconstante podem também ser empregados quando pensamos nelas como uma região de luz depurada e etérea, que se desfaz na superfície acima. Já as sombras mais aparentes estão logo atrás da lycra, próximas aos cantos internos do chassi. Por essa razão, são sombras reais que emergem na superfície da pintura.

Essa pintura em especial me faz lembrar a última exposição da artista carioca Fernanda Gomes, na galeria Luisa Strina no início de 2018. Lembro-me particularmente de uma sala toda branca construída no centro da exposição, em que o teto era revestido por um tecido que tornava a luz no seu interior completamente homogênea (imagem a seguir). Esse procedimento fazia a atmosfera mais densa e os contrastes de sombra e luz diluídos. A sensação era de estar imerso em uma substância aquosa, fazendo os objetos brancos instalados nas paredes terem uma presença quase imperceptível.

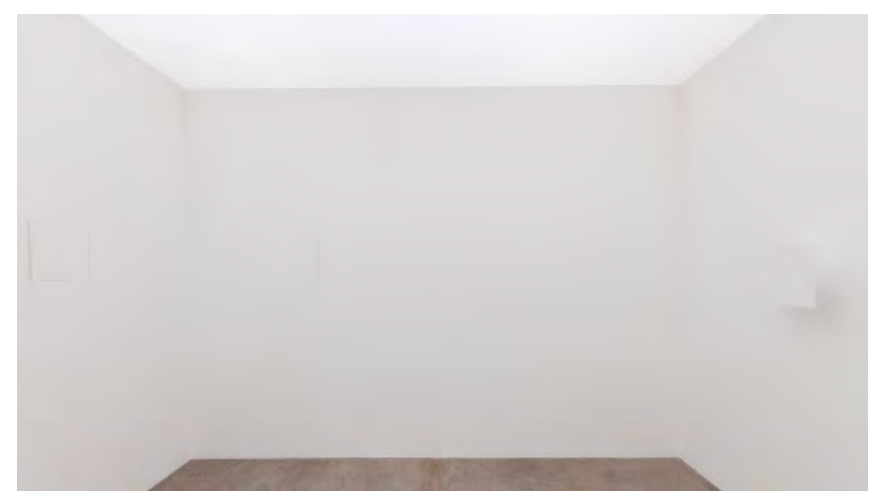

Sala da exposição de Fernanda Gomes, 2018,

Galeria Luisa Strina, São Paulo, 2018.

A obra dessa artista é de grande interesse para minha prática. Ela também aparenta transitar de maneira ambivalente entre linguagens como pintura e escultura,

\footnotetext{
14 Encáustica é uma técnica de pintura que remonta à antiguidade e se caracteriza pelo uso da cera como
} veículo e aglutinante dos pigmentos. A palavra deriva do grego enkausticos, que significa gravada a fogo. 
entre o objeto e o espaço e entre a luz e a sombra, atualizando essas experiências no espectador, como escreveu o curador e diretor português João Fernandes ${ }^{15}$, na ocasião da exposição da artista no Museu Serralves em Portugal ${ }^{16}$.

A simplicidade do material utilizado, basicamente madeira, e das ações que criam as obras, somadas à tinta branca empregada na maioria delas, trazem um significado de pureza, delicadeza e austeridade que parecem anular a matéria das coisas que estão ali, reforçando as inclinações mais contemplativas e espirituais dos seus objetos. Em sua exposição de 2005, também na galeria Luisa Strina, propôs a artista: "Favor não tocar. Silêncio é o acompanhamento ideal."17.

${ }^{15}$ Disponível em: www.serralves.pt/fotos/editor2/FernandaGomes.pdf. Acesso em: 21 jan. 2019.

${ }^{16}$ Exposição Fernanda Gomes, 2006, Museu Serralves, Porto, Portugal.

17 Disponível em: www.galerialuisastrina.com.br/exposicoes/fernanda-gomes-2005/. Acesso em: 21 jan. 2019. 
II. ESPAÇO E MATÉRIA 
A necessidade de conceber uma obra que oferecesse ainda mais concretude a sombras e luzes me levou a realizar trabalhos com mais relevo, corpo e matéria. E a percepção de que essas sombras e luzes extrapolam o objeto foi a razão de considerar o espaço próximo à obra. Desse modo, as questões materiais e espaciais do trabalho são desdobramentos das investigações referentes às sombras e luzes.

As relações de sombra e luz do trabalho parecem, portanto, mediadas pela matéria das obras. Matéria essa que não se limita ao plano da tela e vai em direção às bordas do objeto da pintura: fica aparente certo movimento para o espaço circundante. Assim, pouco a pouco, de maneira gradativa e fragmentada, algumas das pinturas se soltaram do plano pictórico em direção ao espaço próximo, espalhando-se e diluindo-se nas paredes ao redor.

O crítico de arte e professor italiano Lorenzo Mammì (2012) escreve a respeito da vocação da arte de hoje em surgir pelas bordas, em direção a esse espaço próximo:

\begin{abstract}
Muita arte, hoje, nasce pelas bordas. Perdida a confiança nas defesas tradicionais da moldura e do pedestal, que a separavam de antemão do mundo, e já não podendo contar apenas com a coerência formal para manter a identidade, as obras contemporâneas são obrigadas a encontrar estratégias específicas para que possamos entender onde começam e onde acabam.

A colocação da obra no lugar onde será mostrada já não é uma questão posterior à sua feitura, mas algo que participa de sua ideação. O significado parece ter se deslocado do interior da obra para a superfície dela, ou melhor, para o limiar que a separa do mundo.

Se já não aceita o isolamento clássico do mundo, a obra contemporânea continua emanando espaço em volta de si - tende a estruturar o ambiente real ao seu redor como um espaço ideal. Mais precisamente: o espaço em que a obra se põe é, por isso mesmo, carregado de sentido, e esse sentido há de ser determinado pela obra, como se nela já estivesse em potencial. ${ }^{18}$
\end{abstract}

Essa ideia central de deslocar o significado da obra do seu interior para os seus limites com o mundo, incorporando uma parte do espaço à volta, ajudará a compreender os trabalhos que serão comentados a seguir. Esse espaço será sempre impreciso. Quando, por exemplo, foram pintadas as paredes da galeria de um cinza-claro quase imperceptível para inscrever os trabalhos da mostra Apagamento $^{19}$ (removendo luz das paredes que deveriam estar brancas), essas paredes passaram a dizer mais sobre os trabalhos do que sobre o espaço da galeria.

18 MAMMÌ, Lorenzo. O que resta, Arte e crítica de arte. São Paulo: Companhia das Letras, 2012. p. 55.

19 Procedimento já descrito na página 25 no comentário a respeito da obra Luz pintada (fig. 89). 
Mas não se trata, como se poderia sugerir, de uma reflexão abrangente acerca do papel do espaço institucional onde o trabalho se insere. Podemos pensar essas obras atuando no espaço de lugares diferentes dos habituais: o espaço ao redor pode ser as paredes de uma galeria, ateliê ou museu, como também pode ser as de um lugar qualquer. No posfácio que escreveu para a obra $O$ olho e o espírito de Merleau-Ponty, Alberto Tassinari (1999) fala de uma certa fusão da pintura mais recente no mundo:

Entre o mundo da obra e o mundo em comum há uma comunicação na pintura contemporânea dos últimos quarenta anos. A visão da pintura não nos dá as coisas como se vistas através de uma janela, de uma imagem ou de qualquer outra forma de duplicidade em que o mundo da obra replica o mundo. A profundidade não mais a habita. A pintura se mistura com o mundo. ${ }^{20}$

As obras também se desenvolvem no sentido de explorar a percepção que temos das coisas, colocando em suspensão noções de materialidade para revelar conteúdos e substratos menos aparentes dos objetos. Sentidos de luz, sombra, forma, arranjo, superfície, espacialidade e qualidade material podem ser ressignificados, colocando em suspensão o instante em que acaba a percepção e começa o trabalho: "Quando as fissuras entre mente e matéria se multiplicam em uma infinidade de lacunas, o ateliê começa a desabar [...], de modo que mente e matéria se confundem interminavelmente", escreveu o artista norte-americano Robert Smithson ${ }^{21}$.

\section{Obras 2017}

No final de 2016 e início de 2017, começo a realizar algumas experimentações com materiais que tinha à mão: tecidos, madeiras e pregos, muitos deles oriundos da pintura, mas também outros, como ferros, pedras e argila (fig. 65 e 68).

Sem título, 2017 (fig. 65), foi a primeira delas. O trabalho é feito a partir de um tecido de veludo preto que fica pendurado por um pequeno prego. Mais acima, temos uma fina barra de ardósia (1 x 2 × $140 \mathrm{~cm}$ ) apoiada sobre pregos, além de uma pintura de uma faixa branca feita logo abaixo na parede (do lado esquerdo do tecido preso).

\footnotetext{
20 TASSINARI, Alberto. Quatro esboços de leitura. Posfácio. Em: MERLEAU-PONTY, Maurice. $O$ olho e o espírito. Trad. Paulo Neves Maria Ermantina. São Paulo: Martins Fontes, 1999, p. 161.

21 FERREIRA, Glória. Escritos de artistas: anos 60/70. Rio de Janeiro: Jorge Zahar, 2009, p. 191.
} 
Foi nesse trabalho, dentro do espaço do ateliê, onde pela primeira vez realizei uma pintura prévia na parede com uma cor cinza-claro, para poder criar o branco da faixa pintada 22 . Funcionando mais como um exercício do que como uma obra pronta, esse trabalho foi uma experiência que acabou servindo de ponto de partida para as obras que viriam depois.

As diferentes materialidades e formas que compõem esse trabalho estabelecem relações que vão se desdobrando e contrapondo, tal como a relação entre a barra e a faixa pintada, ou a do tecido com o pequeno prego que o sustenta.

Na obra Sem título, 2017 (fig. 68), o tecido preto se afasta da parede ao ser pendurado em uma estrutura de ferro presa ao teto, lembrando um varal. Ao olharmos, percebemos a sombra que se projeta na parede atrás, conferido ainda mais peso ao tecido. A argila branca e retangular à direita é quase como um relevo que brota na parede e parece simular uma pequena tela.

Já Sem título, 2017 (fig. 66), é um objeto de 14,5 x 11,5 cm, fruto de uma ação que envolveu mergulhar o chassi com o tecido pregado em uma lata de tinta acrílica preta de parede. O procedimento é próximo daquele já descrito na obra Luz pintada, 2017 (fig. 78), com a diferença de que aqui o objeto é mergulhado na vertical e diretamente na lata, recebendo tinta também nas laterais e na parte detrás.

Os pregos à mostra e o tecido que não cobre as laterais deixam partes do chassi aparentes, tornando possível enxergar aquilo que geralmente fica oculto em uma pintura, revelando alguns dos materiais que a constituem enquanto objeto.

Nesse trabalho é mais clara a influência do norte-americano Robert Ryman. Seu desprendimento no uso dos materiais que constituem a pintura somado ao modo como o processo artístico é tomado como um fim em si apresentaram-me possibilidades de pensar o trabalho segundo esses mesmos aspectos, relativos, então, à inflexão da matéria da pintura e à explicitação dos procedimentos no corpo da obra.

Em algumas de suas pequenas pinturas temos encadeamentos cromáticos mínimos que derivam de uma tinta branca de consistência matérica generosa, em que parte do tecido cru é deixado à mostra (imagem a seguir).

\footnotetext{
22 Refiro-me ao procedimento já comentado, realizado na exposição Apagamento, de pintar o espaço da
} galeria com uma cor cinza-claro. 


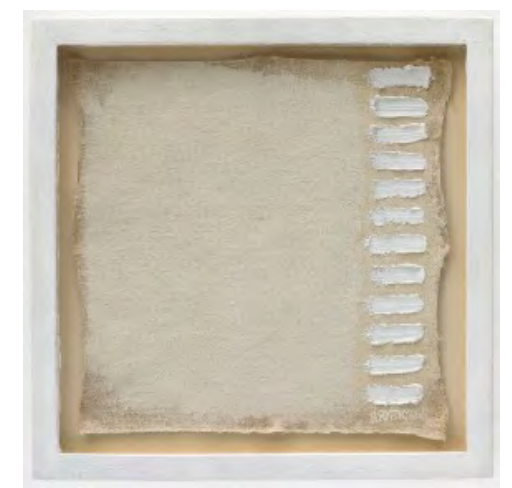

Robert Ryman, A painting of twelve strokes, 1961, óleo sobre tela, $28 \times 28 \mathrm{~cm}$.

Na obra Sem título, 2017 (fig. 70), o trabalho acontece na direção de remover a solidez da forma: o tecido mole que se converte em escultura ao ser mergulhado na tinta acrílica, por exemplo, tenta estabelecer uma forma mais fluida, livre de qualquer urgência de permanência. O chassi, parcialmente preenchido com gesso branco, sem tecido, destaca a estrutura. O prego embrulhado na fita adesiva e pintado de preto traz precariedade ao arranjo. A argila escura, por fim, é uma matéria bruta que imita, numa escala menor, o retângulo do chassi ao lado. São, desse modo, objetos e operações aparentemente desconexos, de materialidades distintas, formando uma composição que lembra uma colagem na qual os elementos não se articulam tão facilmente.

Há, aqui, correspondências com a obra do paulista Paulo Monteiro, um artista de influência para esses trabalhos mais matéricos. Mesclando pequenas pinturas monocromáticas que contêm encorpadas faixas de tinta com esculturas amorfas e esguias feitas de alumínio e chumbo (imagens a seguir), o artista parece trabalhar com sobras: "como se desejassem [as obras] ser apenas aquilo que não se aproveitou e ficou de lado", escreveu o professor Paulo Venâncio Filho ${ }^{23}$.

23 VENANCIO FILHO, P. Rotina e aventura. Em: Taisa Palhares. (Org.). Paulo Monteiro. 1 edição. Cosac \& Naify, São Paulo, 2009, p. 72. 


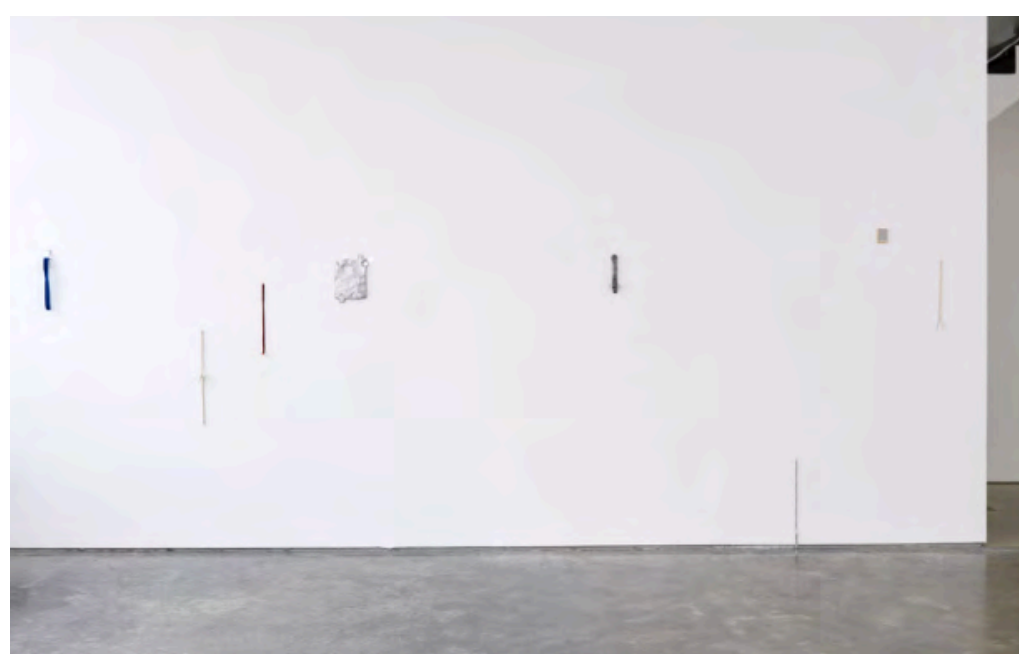

Paulo Monteiro, vista da exposição Where are you?,

Lissson Gallery em Londres, 2014.

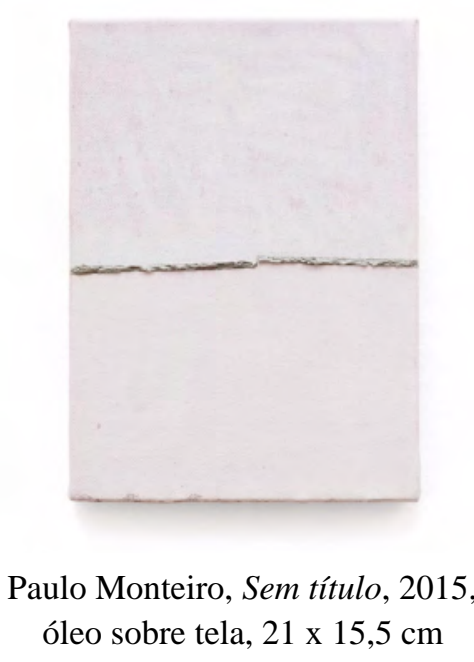

Esse tipo de pintura com uma tinta de matéria mais espessa em certa área da tela também acontece nos meus trabalhos. Em Sem título, 2017 (fig. 69), a tela utilizada foi de tecido de linho preto no lugar de branco. A tinta mais fosca que cobre a maior parte da superfície (onde vemos cores desbotadas e sem brilho) foi bastante diluída. Já o tecido pendurado na pintura é de mesma origem daquele que foi esticado no chassi.

Podemos, então, focar na matéria da tinta a óleo preta na parte superior da pintura, que estabelece um marcante contraste com o restante da composição. Aqui, as relações de luz e sombra são fortemente constituídas pela matéria da tinta: o óleo é entremeado por luzes e sombras, com predomínio de uma ou outra, conforme a rugosidade ou lisura da região. Na parte mais lisa à direita, por exemplo, estabelece-se 
uma superfície especular negra onde é possível ao observador (dependendo do ângulo e da luz) ver o próprio reflexo na tinta.

Esse trabalho, de algum modo, faz pensar na obra Espelho Cego (1970) de Cildo Meireles (próxima imagem), que consiste em uma matéria cinza, opulenta e disforme acomodada no interior de uma moldura com os cantos arredondados. A natureza reflexiva do espelho é completamente desmantelada. A respeito dessa obra, o professor Jaime Ginzburg escreveu no seu artigo Cegueira e literatura (2004):

O choque provocado pela redução de uma imagem especular a pura ruína é muito intenso. $\mathrm{O}$ espectador, se sustentar o olhar, se perguntará pelos limites da própria percepção, limites que estabelecem uma impossibilidade de deixar fluir a visão. O que está sendo visto, o que pode ser visto? É a própria visão do espectador que percebe seu limite, sua incapacidade de ver.

A obra aponta para uma forma de subjetividade que exige atenção. Contrariando as heranças vindas do pensamento cartesiano e do Iluminismo, encontramos aqui a projeção da imagem de um sujeito que não tem condições de organizar a produção do conhecimento. Essa limitação faz com que se volte sobre si, atingido pela própria incompreensão. É um sujeito que, descobrindo uma distância entre sua autoimagem habitual e inesperadas imprecisões, está aquém de si mesmo. ${ }^{24}$

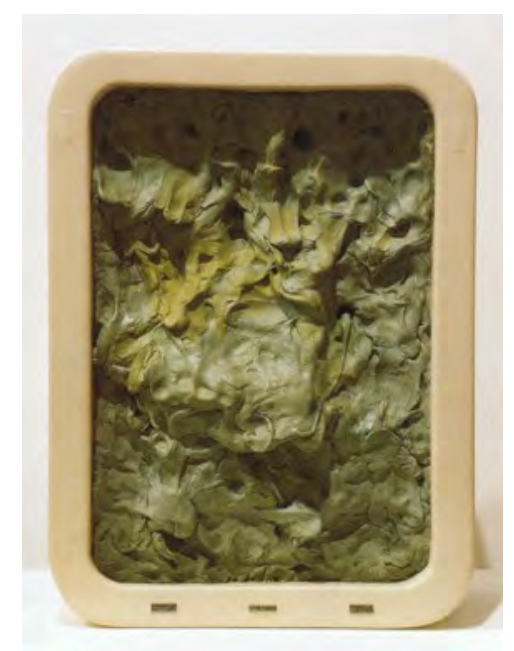

Cildo Meireles, Espelho Cego, 1970, madeira, massa de calafate, $49 \times 36 \times 24 \mathrm{~cm}$

Em Espelho Cego é incontornável que o sentido de sua matéria desarranjada esteja ligado à ideia de um espelho onde não é possível se ver. Enquanto que em Sem título (fig. 69) isso é apenas uma das possibilidades que emerge da matéria preta da tinta, até porque em alguns instantes ela tem, com efeito, qualidades especulares,

${ }^{24}$ GINZBURG, Jaime. Cegueira e literatura. São Paulo: Aletria, 2004. 
produzindo em nossa percepção certos movimentos que parecem incertos, mas que, por isso mesmo, permitem existir sentidos vários, em simultâneo, no corpo do trabalho.

\section{Apagamento, 2017}

Realizada entre julho e setembro de 2017, a exposição individual Apagamento (figs. 97-100) foi fundamental para minha experiência no PPGAV durante o primeiro ano, uma vez que foi o momento em que pude aliar a prática artística à reflexão e à pesquisa. A experiência dessa mostra foi determinante porque reuniu pensamentos que até então estavam dispersos.

No primeiro semestre de 2017, no mesmo momento em que cursava as duas primeiras disciplinas do programa de mestrado ( $O$ Espelho Fragmentado e Corpo, Rosto e Retrato na Arte Moderna e no Cinema), encontrava-me também às voltas com Apagamento, imerso na produção de obras e na concepção e elaboração da exposição. Consequentemente, Apagamento foi diretamente influenciada por aquilo que estava sendo discutido nessas disciplinas.

Já em relação ao segundo semestre, após a abertura, tive a chance de, com a mostra ainda em exibição na galeria, refletir acerca dela nos meus seminários dos cursos Cor e Cidade e Margens e Imagens, Molduras e Pedestais.

Algumas das obras dessa mostra já foram abordadas na primeira parte do texto (Sombra e Luz). Agora, a intenção é comentar e pensar a respeito da mostra como um todo, refletindo principalmente acerca dos sentidos espaciais e materiais de suas obras.

Apesar das dimensões reduzidas de algumas telas e objetos, é indispensável uma certa distância para olhar as obras dessa exposição. Esse afastamento é necessário tanto para observar os jogos de sombra e luz criados ao redor dos trabalhos como para notar a expansão da matéria que acontece em alguns deles.

Se nas pinturas iniciais já foi possível notar a remoção de elementos, cores e camadas, essa ação passa a acontecer também como um exercício de desconstrução do suporte da pintura, chamando a atenção para suas partes, tal como a redução dos gestos a operações mínimas, conforme vemos na pintura Sem título, 2017 (fig. 81). Essa obra se resume a um corpo de tinta a óleo azul-escuro concentrado no canto esquerdo inferior 
de uma tela, acompanhado de um pequeno tecido enrugado que foi mergulhado em tinta acrílica preta e colocado ao lado dela.

Para melhor compreensão desses movimentos, podemos também olhar para a obra Sem título, 2017 (fig. 71). Nessa pintura (em que a tinta a óleo azul ultramar é aplicada na extremidade inferior direita da tela) temos uma espessa e estreita camada de tinta escapando da demarcação imposta pela geometria do suporte, salientando toda sua fisicalidade e materialidade para além dos limites dessa pintura, como uma matéria que está prestes a se desagarrar do objeto.

Esse procedimento de aplicar a tinta no limite do suporte é igualmente presente na obra Sem título, 2017 (fig. 72), na qual a tinta a óleo verde-escuro foi posta na base da tela, com uma espátula, direto sobre o chassi de madeira, o que só foi possível graças ao tecido dobrado um pouco antes de alcançar a base do chassi, deixando aparente essa parte da madeira que recebeu a tinta.

O sentido de dissolução da tela aparece quando olhamos para a obra Sem título, 2017 (fig. 74). Nela, vemos uma sobra de tecido deixada no momento de esticar a tela, que depois foi mergulhada em uma tinta acrílica branca. Quando secas, essas sobras se plasmaram em um sólido fosco, que parece estar se desprendendo do suporte. A sensação é que a tinta decantou da superfície, como se a pintura tivesse se desfeito por algum processo natural de depuração, deixando para trás uma pintura sem tinta.

Esse movimento se desdobra em Sem título (fig. 75), 2017. Aqui, a tinta da superfície da tela se soltou completamente, formando "estalactites" duras de tinta. A ambiguidade de criar sólidos por meio de tecido e tinta coloca essas peças em um lugar entre a pintura e o volume escultórico.

O chão seria o destino final desse movimento da tinta, o qual podemos separar em três momentos: quando começa a se desvencilhar do suporte (fig. 74), quando se isola na parede (fig. 75) e, por último, quando se deposita no chão (figs. 76 e 77). Assim, Sem título, 2017 (fig. 76), encerra um movimento que aparenta ser conduzido por uma força da gravidade que só atua sobre aquilo que é a substância vital da pintura. O que sobra, representado pela chapa de compensado, é tão somente a forma retangular do suporte.

Trabalhos como esses falam a respeito de formas e matérias densas que estão em estado contínuo de agitação, na iminência de desmoronarem aos nossos pés, lembrando- 
nos do seu feitio passageiro, lembrando-nos que não é possível represar seu fluxo natural por tempo indeterminado. "Toda formalização é um ato de soberba, natural é desfazer-se [...] formalizar é estancar uma matéria que escoa"25.

\section{Simulações (projeto não realizado), $2017^{26}$}

O trabalho Simulações, 2017 (figs. 89-90), seria montado no espaço da recepção do Pivô, uma associação cultural sem fins lucrativos localizada no edifício Copan, em São Paulo. A obra consiste em duas peças feitas para ficarem sobre as faces mais planas da coluna de sustentação do prédio, acompanhadas de uma lâmpada e uma barra de ferro penduradas ao teto (fig. 89).

A primeira peça é uma estrutura de ferro vazada e pintada com tinta acrílica preta fosca $(225 \times 85 \times 4 \mathrm{~cm})$ que ficaria encostada na face da coluna virada para a porta de entrada. Essa estrutura imitaria uma das secções da esquadria de ferro que suporta o revestimento de vidro da fachada (fig. 90). Logo à frente dessa peça, haveria uma lâmpada fluorescente pendurada ao teto entre a entrada e a coluna. Ainda desse lado, seria pintada uma sombra simulada diretamente na coluna, como se a estrutura de ferro vazada projetasse uma sombra cheia (fig. 90).

$\mathrm{Na}$ outra face mais plana dessa coluna, voltada para a porta do elevador, seria fixada uma espuma forrada com tecido cinza que replicaria as dimensões da estrutura de ferro vazada (fig. 89). Por fim, ainda desse lado, seria pendurada uma barra de ferro cilíndrica pintada de preto fosco com as mesmas dimensões e na mesma altura da lâmpada suspensa do outro lado.

Por ser um espaço sem muitos ângulos retos, cantos ou paredes planas, a obra teria como ponto de convergência a grande coluna arredondada de sustentação. Por essa razão, a intenção era que as peças fizessem referência entre si, que pudessem reafirmar algo de contínuo e cíclico que acontece em torno da coluna. Assim, a barra cilíndrica de ferro faria referência à lâmpada, da mesma maneira que a espuma forrada de tecido faria

\footnotetext{
25 Retirado do texto A queda do mundo (2013) de Lorenzo Mammì, que trata da obra Sala de espera de Carlito Carvalhosa. Disponível em: http://carlitocarvalhosa.com/textos/143. Acesso em: 2 abri. 2019.

26 Projeto não realizado para intervenção na recepção do Pivô de 2017.
} 
referência à estrutura de ferro, que, por sua vez, faria referência a toda a esquadria envidraçada desse espaço.

$\mathrm{Ou}$ seja, o trabalho aconteceria por meio de peças que refletem um dos elementos arquitetônicos do lugar, ao mesmo tempo em que novos jogos de sombra e luz seriam produzidos no seu interior, estabelecendo outras maneiras de articulação do espaço, o qual ficaria imerso em reflexos, sombras, transparências e repetições inesperadas.

Na mostra Exercício de divisão, 2018 (imagem a seguir), do artista Marcius Galan, realizada na galeria Francisco Fino, em Portugal, as ideias de simulação, duplicação e reflexo são igualmente muito presentes. Servindo-se de estruturas, objetos e operações que se repetem precisamente em dois lados do espaço - criando duplos — de modo que temos a impressão de existir um gigantesco espelho bem no centro da galeria, que a cinde ao meio. $\mathrm{O}$ artista simula uma imagem especular completa e simétrica desse ambiente. Daí a proximidade com Simulações no que diz respeito à tentativa de desdobrar elementos e conceber ilusões que tornem o espaço mais complexo e indeterminado.

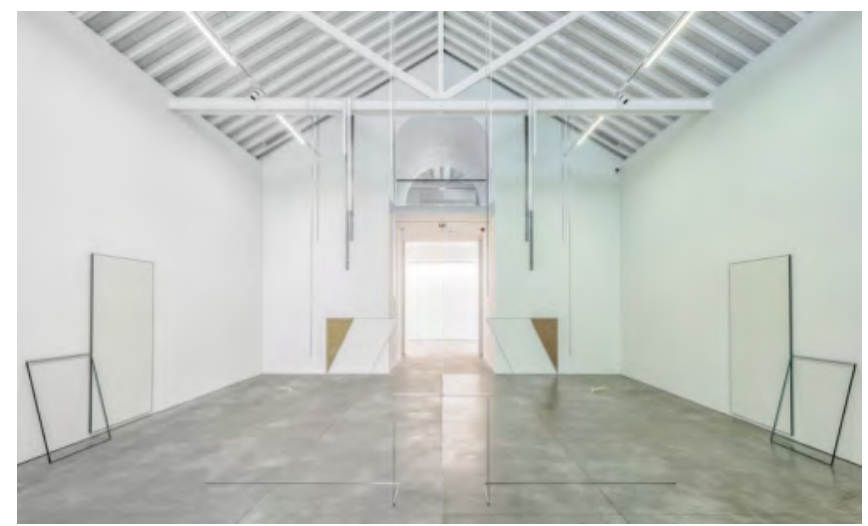

Vista da exposição Exercício de divisão, de Marcius Galan Galeria Francisco Fino em Lisboa, 2018.

Em obras como Translúcido I, 2015 (próxima imagem), vemos uma estrutura de ferro acompanhada de uma pintura feita da parede ao chão que cria a percepção de existir um vidro ali — somos induzidos a completar a estrutura com vidro -, a miragem só termina após um olhar mais cuidadoso revelar o artifício. 


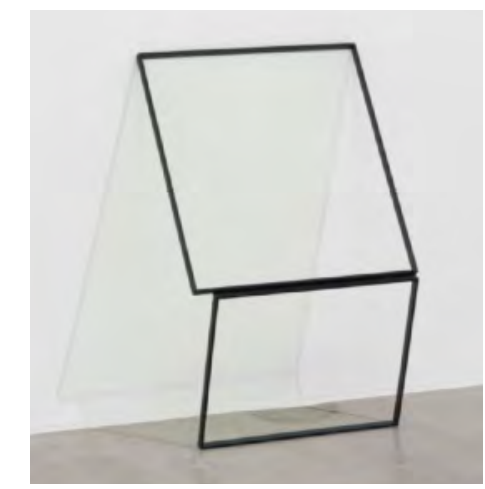

Marcius Galan, Translúcido I, 2015,

Ferro pintado e pintura na parede e no chão, $88 \times 76 \times 38 \mathrm{~cm}$

A pintura da sombra inventada em Simulações pode funcionar da mesma maneira: criando, igualmente, percepções forjadas. No entanto, a sua finalidade principal é estabelecer um embate com a luz emitida pela lâmpada logo à sua frente, criando contrastes marcados que se sobrepõem.

O fato de esse trabalho existir apenas enquanto projeto também não pode ser desconsiderado. Não é possível prever todas as relações que a obra estabeleceria com o lugar concreto, uma vez que muitas variáveis se apresentam apenas no instante da execução. Em todo caso, muitas dessas dúvidas não se esgotam no trabalho concluído, algo de vacilante e indeterminado não deve para de atuar nesse trabalho, em que reflexos, transparências, sombras e luzes não são instâncias definitivas.

\section{Janela Rasa (projeto não realizado), $\mathbf{2 0 1 8}^{27}$}

Janela Rasa, 2018 (figs. 91-92), é uma instalação de ferro, espelho e pigmento, içada ao teto, que teria como proposta imitar (assim como a estrutura de Simulações) uma das secções da esquadria que suporta o revestimento de vidro do prédio do CCSP, funcionando como uma imitação dessa estrutura.

A obra contraporia a função fundamental da estrutura ao utilizar um espelho negro no lugar de um vidro translúcido - que permitiria a fluidez da luz natural —, produzindo um reflexo escurecido do seu entorno. Dessa maneira, ao invés da 
transparência, o observador seria confrontado com o próprio reflexo apagado na superfície do espelho negro (fig. 91).

$\mathrm{Na}$ borda inferior desse espelho haveria acúmulo de pigmento preto aplicado com cera de abelha, estabelecendo, assim, a partir da maleabilidade da cera, oposição à forma rígida do ferro e do espelho. A encáustica, como já dito, é uma técnica antiga de pintura que se vale da cera de abelha como veículo para a aplicação do pigmento em alguma superfície. Por essa razão, Janela Rasa também incorpora algum sentido de tela ao objeto.

Ao olhar para esse espelho, teríamos a impressão de que a imagem é feita da mesma matéria da cera preta da base, como se brotasse dela para erigir o reflexo logo acima. E a imagem que veríamos ao nos aproximar seria a do entorno e a dos nossos próprios corpos da cintura para cima (já que o espelho ficaria a uma distância de aproximadamente um metro do chão e teria dimensões de algo como 140 x $310 \mathrm{~cm}$ ), estabelecendo, desse modo, um reflexo escurecido e impreciso de ambos. 


\section{REFLEXOS DO CORPÓREO}

É oferecendo seu corpo ao mundo que o pintor transforma o mundo em pintura Maurice Merleau-Ponty, $O$ olho e o espírito 
Algo a respeito do corpóreo sempre esteve presente nos trabalhos. Desde as primeiras pinturas a tela era sempre acomodada na vertical, ficando de pé no cavalete. Essa inclinação pela verticalidade do suporte não era muito clara naquele momento, talvez eu pensasse que fosse uma escolha casual, sem maiores implicações para aquilo que buscava ao pintar. Só compreendi sua importância quando tentei realizar pinturas na horizontal e tive dificuldades para continuar.

Não é que eu não tenha tido sucesso nesses trabalhos, mas a tela deitada trazia consigo sentidos de paisagem e horizonte quase que incontornáveis. Essa disposição não satisfazia alguma necessidade interna de forma: a pintura precisava de algo mais relacionado com uma corporeidade que o suporte na vertical parecia ecoar, e essa urgência, da qual tomava consciência naquele momento, tinha relação com um certo reflexo de uma fisionomia essencial do corpo ereto (fig. 31).

O crítico de arte norte-americano Leo Steinberg (2008), em Outros critérios, chama a atenção para o plano do quadro do Renascimento até a pintura expressionista abstrata, por essas pinturas convocarem "dados sensíveis que são experimentados na postura ereta normal":

Um quadro que faz alusão ao mundo natural evoca dados sensíveis que são experimentados na postura ereta normal. Desse modo, o plano do quadro do Renascimento afirma a verticalidade como sua condição essencial. E o conceito do plano do quadro como uma superfície vertical sobrevive às mais drásticas mudanças de estilo. Os quadros de Rothko, Still, Newman, De Kooning, e Kline ainda nos são dirigidos de cima para baixo, assim como os de Matisse e Miró. São revelações com as quais nos relacionamos visualmente do alto da coluna que constitui o corpo humano; e isso se aplica também às pinturas gotejadas de Pollock, de fato, derramava e gotejava suas tintas sobre as telas estendidas no chão, mas isso era uma técnica de trabalho. Assim que as primeiras tramas de tinta eram depositadas, ele prendia a tela na parede para tomar conhecimento dela, como dizia -, para ver que direção ela queria seguir. Convivia com a pintura em seu estado vertical, como com um mundo confrontando sua postura humana. 28

O meu interesse na obra de Barnett Newman vai nessa direção: está na possibilidade de algumas das suas pinturas atuarem em nossa percepção relacionada ao corpo em pé: aquilo que seria o caráter essencial de nossa estatura e escala humana, aquilo que nos mantêm de pé e nos distinguiria de outros animais e coisas ${ }^{29}$. Refiro-me

\footnotetext{
28 STEINBERG, Leo. Outros critérios; trad. Célia Euvaldo. São Paulo: Cosac Naify, 2008, p. 116.

29 DIDI-HUBERMAN, Georges. O que vemos, o que nos olha. Trad. Paulo Neves. São Paulo Editora 34, 2010, p. 122.
} 
ao Zip: faixa única na vertical pintada no centro de algumas de suas telas que torna possível a tomada de consciência da simetria bilateral ${ }^{30}$ do observador, medindo-o e revelando sua presença, como se a faixa repercutisse uma certa condição primordial do corpo ereto logo a sua frente (imagem a seguir). Não se trata aqui de uma representação ou substituição do corpo ereto, como nos lembra o historiador e filósofo da arte francês Yve-Alain Bois (2009):

Apesar das fortes conotações antropomórficas contidas em qualquer configuração simétrica, creio que seria errado interpretar Onement I, como uma espécie de retrato misterioso do homem como tal [...] A pintura de Newman não representa o homem, nem mesmo "abstratamente"; ela adota uma espécie de investigação fenomenológica no interior da natureza da percepção, isto é, no interior daquilo que, em si, torna possível algo semelhante ao homem. ${ }^{31}$

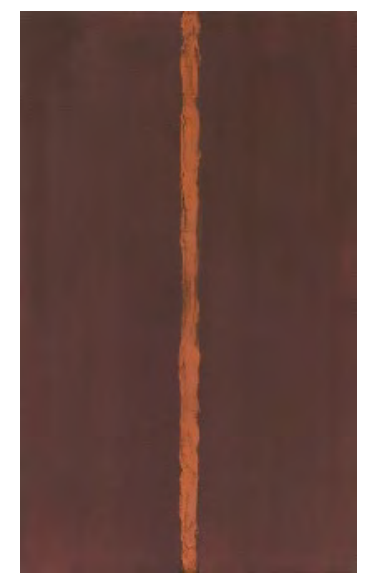

Barnett Newman, Onement I, óleo sobre tela, 68,5 x 40,6 cm, 1948.

A obra Sem título, 2016 (fig. 50), uma pedra de ardósia pintada de 150 x 3 x 1,5 $\mathrm{cm}$, que fica apoiada à parede, funciona com uma lógica próxima daquela do Zip de Newman, no sentido de evocar o corpo ereto na percepção da obra. Mas Sem título, diferente de Onement I, não é uma pintura, mas sim uma peça no espaço de fato, com seu próprio corpo, colocada próxima ao lugar que estamos, gerando um embate mais direto e físico conosco.

Esse trabalho, do mesmo modo que alguns outros já comentados, como Sem título (fig. 75), Sombra pintada (fig. 83) e Sem título (fig. 85) da exposição Apagamento,

\footnotetext{
30 Divisão imaginária que segmenta o corpo de um animal em duas metades iguais.

31 BOIS, Yve-Alain. A pintura como modelo; trad. Fernando Santos. São Paulo: Martins Fontes, 2009, p. 234.
} 
pode também falar da ideia de uma corporeidade que é só sugerida: um corpo que parece não se afirmar enquanto imagem completa, existindo apenas na condição de vestígio. O que resta são apenas seus fragmentos e reflexos imprecisos e difusos, que parecem habitar e se mover por um espelho fraturado, oferecendo-se apenas na qualidade de uma experiência inconclusa.

\section{Cabos, 2018}

Mais recente, a obra Cabos, 2018 (fig. 88), constituída por três extensores para pintura suspensos no ambiente por fios transparentes de nylon, são colunas que parecem lançar um certo ar de altivez sobre o observador: primeiro pela altura superior ao nosso olhar (precisamos levantar a cabeça para enxergar o topo dessas hastes que superam os dois metros e meio de altura, nos colocando em uma posição inferior), e segundo por conta das suas formas esbeltas que transmitem aprumo. Por isso, não gera uma conexão imediata com o corpo do observador, desperta, na verdade, uma situação de assimetria e confronto entre o corpo da obra e o corpo do espectador.

O monólito negro do filme 2001: Uma odisseia no espaço, 1968, do diretor norte-americano Stanley Kubrick (imagem a seguir), funciona de maneira muito parecida ao interagir com os primatas e humanos durante a trama: elevando-se a uma altura que supera esses corpos, colocando-se em lugar de destaque. O volume simples e alienígena de Kubrick seria assim "o grau zero da forma”. É provável que o cineasta tenha olhado para as obras dos seus contemporâneos e conterrâneos, os artistas chamados de minimalistas, em especial para Donald Judd (imagem a seguir), ao conceber o seu monólito extraterrestre. 


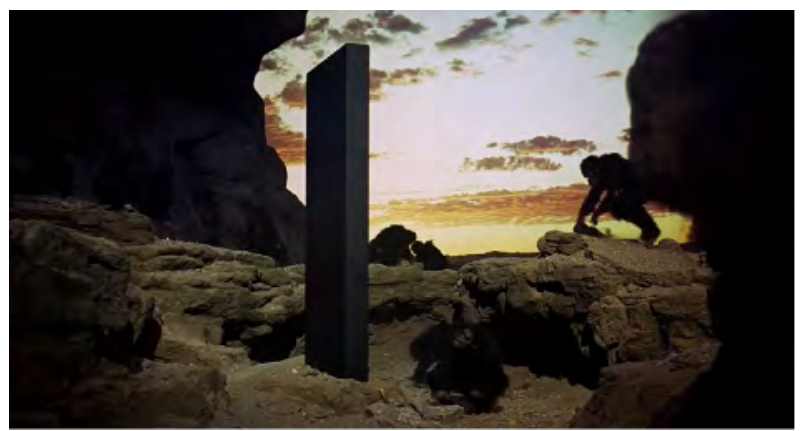

Cena do filme 2001: uma odisseia no espaço, 1968, dirigido por Stanley Kubrick.

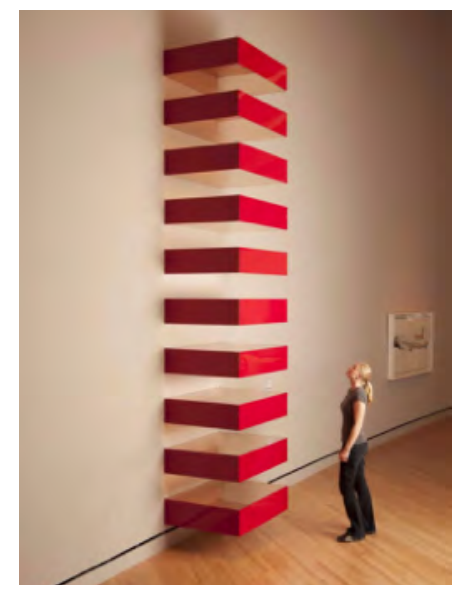

Donald Judd, Sem título, 1966.

Cabos não contém somente esse aspecto purista do objeto que dilui o sentido da obra, uma vez que não se sustenta apenas com qualidades específicas e fundamentais da formar e do material: os gestos imprimidos com a tinta na parte inferior das hastes nos fazem lembrar de atributos relacionados ao procedimento artístico - de uma subjetividade aparente. As marcas de tinta branca e vermelha, construídas a partir de pinceladas curtas, que, além de encenarem os respingos de tinta gerados pelo uso comum dessa ferramenta do pintor de parede, são, principalmente, os vestígios da mão e do corpo no objeto.

\section{Matéria e Corpo (projeto em andamento), 2018}

Matéria e Corpo, 2018 (figs. 93 e 94), refere-se, através da verticalidade de peças e pinturas, à ideia de um corpo ereto, que irá repercutir em todos aqueles que circularão no espaço expositivo. 
Será utilizada uma pequena barra de ouro que ficará em uma cavidade de 5 x 8 x $1 \mathrm{~cm}$ feita no piso. Haverá ainda uma escultura de madeira de 166 x 4 x $4 \mathrm{~cm}$ com ângulo de 10 graus de inclinação entre sua parte superior e inferior. A escultura será apoiada à parede central e em uma cavidade feita no piso, junto à barra de ouro. Também serão pintadas 5 faixas cinzas de 166 x $4 \mathrm{~cm}$ que retratarão sombras fictícias. Essas pinturas estarão distribuídas simetricamente nessa mesma parede (fig. 93).

No centro da parede da esquerda, teremos uma pequena peça de argila, um trabalho de 5,5 x 3,5 x 2 cm, 2017 (fig. 80), que fez parte da exposição Apagamento.

A respeito da iluminação, um foco de luz mais intenso e amarelado deverá ser direcionado na pequena barra de ouro para enfatizar seus volumes e brilho. O restante do espaço poderá ter uma iluminação regular e homogênea.

Com isso, as sombras falsas pintadas e a manipulação da iluminação proporcionarão ao espaço expositivo certa dimensão cenográfica: emprestando aos objetos e pinturas que compõem a mostra um caráter teatral, jogando com as suas presenças físicas.

A obra fundirá corpo e matéria em uma única sensibilidade. O verbo fundir não é por acaso, o ouro em seu estado puro é mole demais para ser utilizado, sendo normalmente fundido em liga metálica. Já a argila, é uma mistura que congrega minerais. Por isso, fundir-se com outra substância é próprio a esses materiais, logo, fundir materialidades à experiência do corpo é central à obra.

\section{Fragmento, 2013}

Mesmo quando o corpo está literalmente presente na obra, caso das performances que discutiremos a seguir, ele parece desfeito pelos gestos e reflexos que os compõe. Essas duas performances, Fragmento e Flutuações, foram realizadas no final do curso de graduação em 2013.

A primeira delas, Fragmento $^{32}, 2013$ (fig. 29), é uma obra elaborada com um colega de turma, Caio Guedes, em uma das aulas da graduação ministrada pelo professor Mario Ramiro, que tratou de ideias referentes aos conceitos de escultura flexível e escultura de minuto, inspiradas pela obra do artista austríaco Erwin Wurm. A

\footnotetext{
32 Disponibilizo o registro em vídeo da performance no link: https://youtu.be/DWAcfTcXu5U.
} 
obra mostra um indivíduo de roupas cinzas à frente de uma parede também cinza onde interage com um cobertor de emergência térmico. Ao manipular esse cobertor estalos são ouvidos, semelhantes aos de uma sacola plástica sendo amassada. A interação com o objeto vai se desdobrando e se intensificando em uma dinâmica que perdura por todo o ato.

Feito de um fino filme de plástico PET metalizado, leve e reluzente, o cobertor térmico é utilizado para manter o calor corporal de pessoas que podem estar sofrendo de hipotermia, uma vez que, além de refletir a luz, tem a propriedade de refletir o calor irradiado. É um item comum em kits de primeiros socorros e frequentemente utilizado pela polícia para cobrir corpos de vítimas fatais de acidentes ou crimes. Tem-se, então, um significado simbólico relacionado ao corpo muito presente. Na obra, é como um invólucro fúnebre de um corpo ainda em estado de animação.

Por isso, dobrar, enrolar, amassar, esticar, cobrir e vestir convertem-se em ações onde o cobertor tenta envolver o corpo, enquanto esse corpo não se sujeita completamente, agitando-se e manipulando o material de volta.

O registro realizado coloca o performer exatamente no centro da cena. Atrás dele vemos três placas de cor cinza-escura próximas à cor da roupa do próprio artista, dando, com isso, maior destaque ao metálico fulgurante do cobertor que reflete a luz do teto, produzindo um tipo de "aura luminosa".

A performance foi gravada dentro do prédio da faculdade de arquitetura da USP, em um dos seus corredores durante o horário matutino das aulas. Em razão disso, é possível escutar vozes e ecos indeterminados que se mesclam com os estalos do cobertor manipulado. $\mathrm{O}$ barulho desses estalos chega a ser incômodo depois de um certo tempo, suas frequências agudas dão a sensação de pequenas agulhas espetando nossos ouvidos.

\section{Flutuações}

Flutuações, 2013 (fig. 30), é uma performance em que o artista está trajado de preto sobre uma pilha de ardósia em um espaço esvaziado onde se penteia repetidas 
vezes à frente de um vidro espelhado preso ao teto ao ritmo de loops sonoros de frequências graves ${ }^{33}$.

Esse trabalho é centrado em um ritual ordinário, um gesto simples e cotidiano: o ato de se pentear à frente de um espelho. A peça sonora, tocada simultaneamente com o gesto, age igual a um marcador temporal e, devido a suas frequências graves, inunda toda a arquitetura e corpos, através dos deslocamentos de ar e ressonâncias. A pilha de pisos de ardósia funciona como base/pedestal, revestindo o corpo do artista de um sentido escultórico. $\mathrm{O}$ vidro espelhado preso ao teto, sem nenhuma moldura, paira no centro do espaço, como se o artista flutuasse ao realizar seu gesto de embelezamento.

Ao longo de toda a performance o artista encara sua própria imagem refletida na superfície do espelho. A imersão nessa imagem é completa já que o espelho tem exatamente o mesmo tamanho do artista — produzindo um espelhamento completo obrigando o performer a confrontar a imagem do corpo na sua totalidade.

A pilha de ardósias empregada no trabalho tem o mesmo sentido da base do monumento clássico: destacar o seu objeto das demais coisas do mundo. Ao subir nessa base, o espelho é acessado e o corpo do artista é evidenciado. Assim, o corpo do performer se transforma em um objeto escultórico vivo, da mesma maneira como fazem os artistas de rua conhecidos por "homens-estátuas".

Flutuações gera um reflexo do ambiente. Assim como o espelho içado que reflete a luz, as ressonâncias e reverberações acústicas geradas na execução dos loops sonoros refletem e evidenciam o ambiente arquitetônico. Mesmo existindo a base (o ponto focal onde a performance acontece), a obra perde seus contornos e espaço próprios, tudo ao redor se funde por conta do som.

Há nesse áudio executado o som de um pedal que se repete constantemente. Sua função é marcar o tempo, remetendo ao som que faz o ponteiro de segundos de um relógio. Mas, ao prestarmos atenção a esse som, sua função vai se dissolvendo, algo tautológico acontece. Assim, através dos loops sonoros, tanto a dimensão espacial quanto a temporal do lugar vêm à tona no corpo da obra.

\footnotetext{
33 Disponibilizo o registro em vídeo da performance no link: https://youtu.be/w-aF6WBDDv8. Recomendo que o vídeo seja assistido em um sistema de áudio que consiga reproduzir com alguma fidelidade as frequências mais baixas para que seja possível escutar e sentir a peça sonora de subgraves.
} 
Chamo também a atenção para o registro de Flutuações. As questões de formalização desse vídeo (relacionadas a enquadramentos de câmera, posicionamento da luz e captação de áudio e locação) não fizeram parte do trabalho na sua concepção original, no entanto, não é possível desprezá-las ao assistir a gravação.

As luzes de led posicionadas no chão simulam a iluminação predominante nos monumentos espalhados pela cidade. Logo, sustenta a percepção do corpo do performer enquanto encarnação da escultura. Essa luz focada que se projeta de baixo para cima traz dramaticidade e enfatiza os contornos e volumes do corpo.

O áudio capturado no local foi substituído pela trilha bruta com o loop de graves produzidos por um sintetizador virtual. O objetivo foi não reproduzir no registro em vídeo os ecos, ressonâncias e reverberações específicas desse lugar onde a performance foi filmada. A intenção é que a peça sonora se relacione diretamente com o lugar onde for reproduzida, já que cada espaço tem suas características próprias. Com isso, a experiência de ouvir a performance ao vivo ou pelo registro são aproximadas. 
IV. OBRAS 


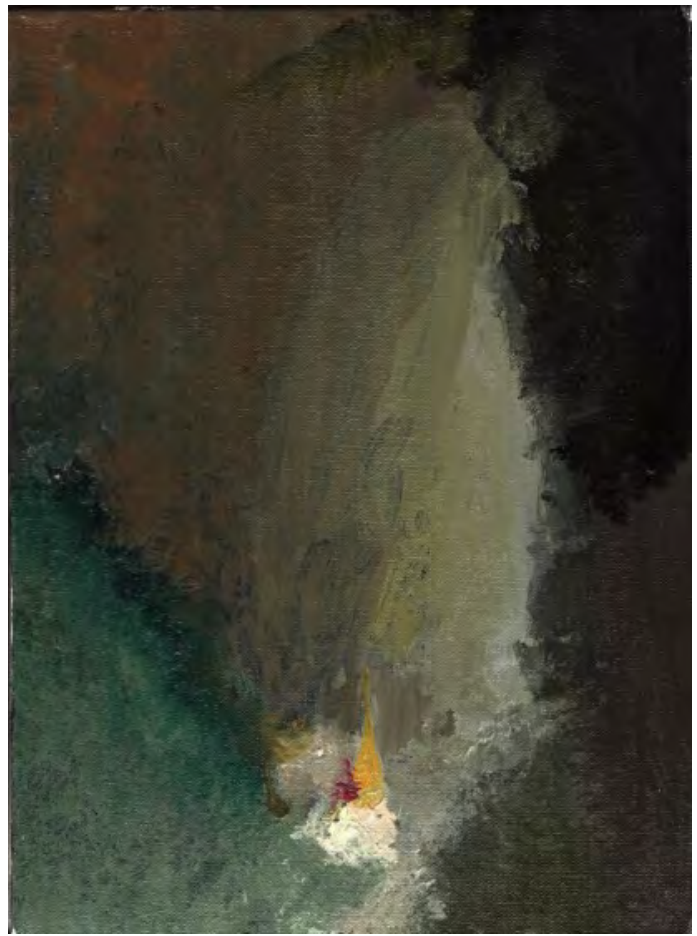

Fig. 1

Sem título, 2011

Acrílica sobre tela, 22 × $16 \mathrm{~cm}$

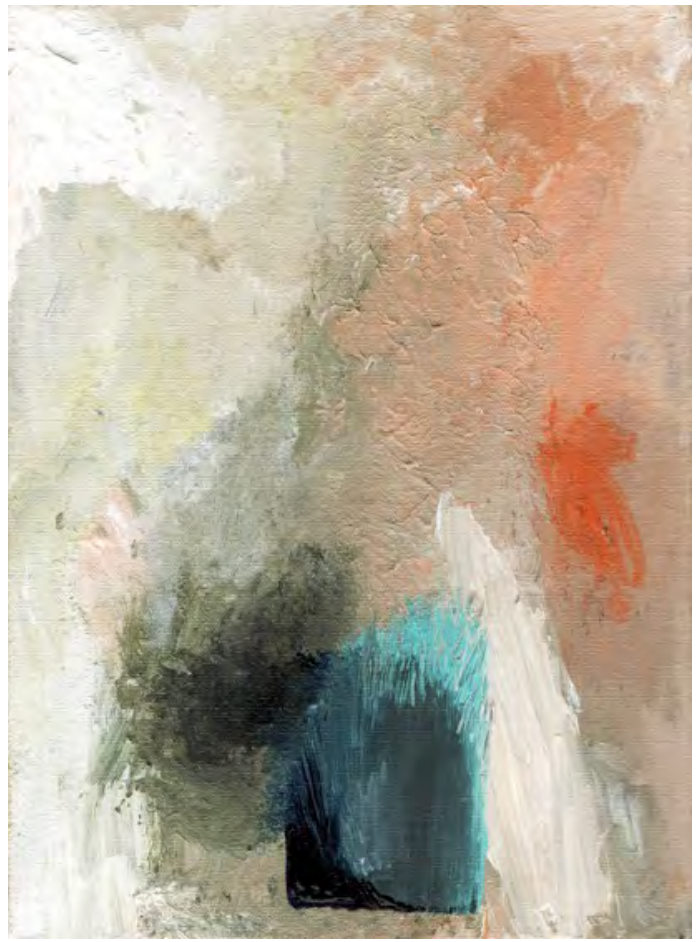

Fig. 2

Sem título, 2011

Acrílica sobre tela, $22 \times 16 \mathrm{~cm}$ 


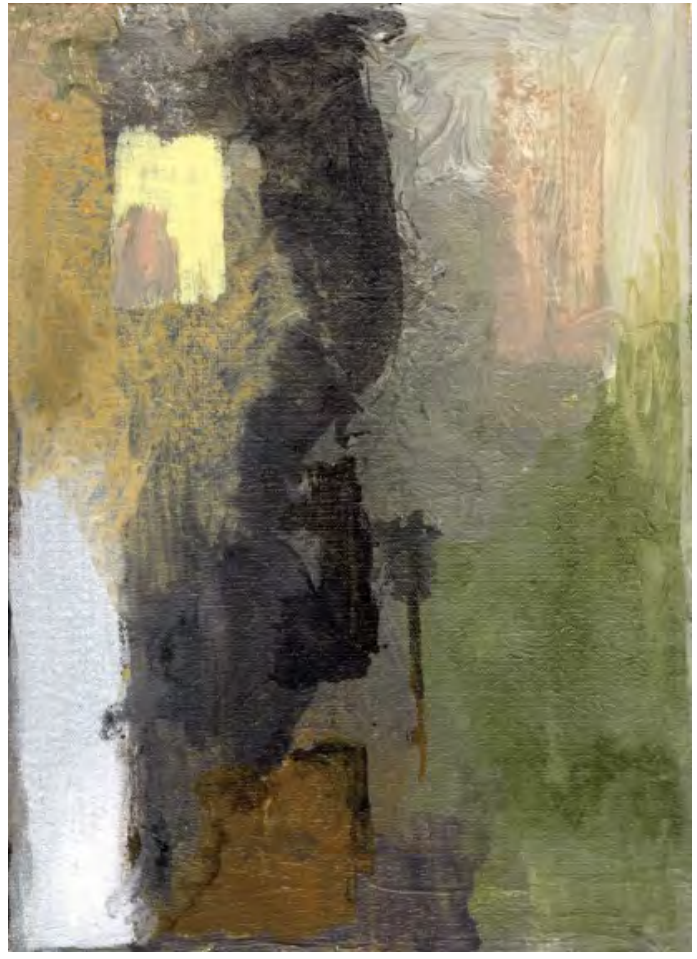

Fig. 3

Sem título, 2011

Acrílica sobre tela, $22 \times 16 \mathrm{~cm}$

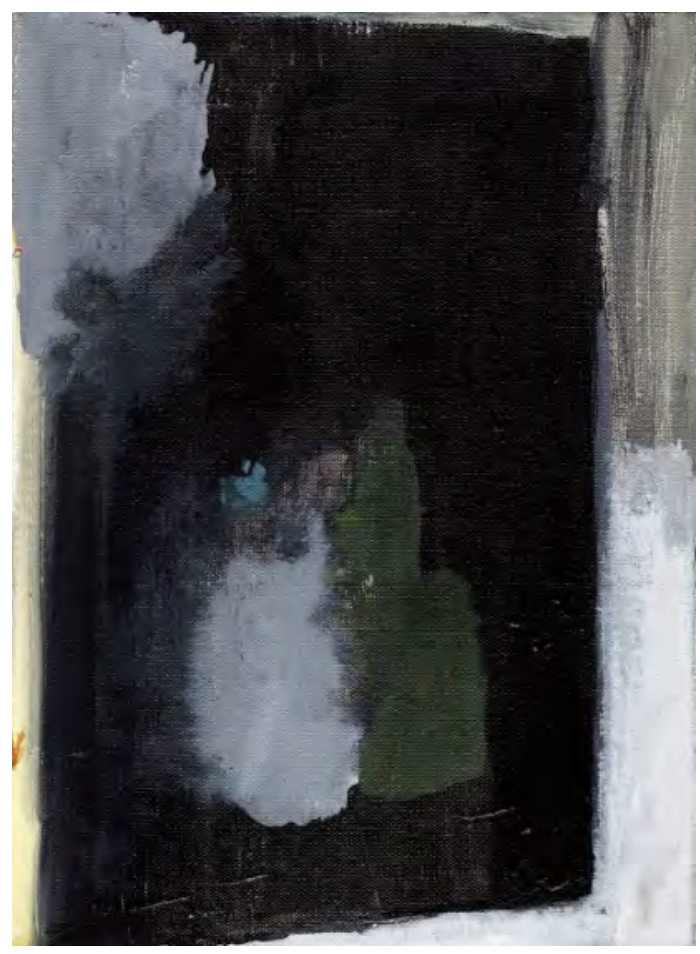

Fig. 4

Sem título, 2011

Acrílica sobre tela, 22 × $16 \mathrm{~cm}$ 


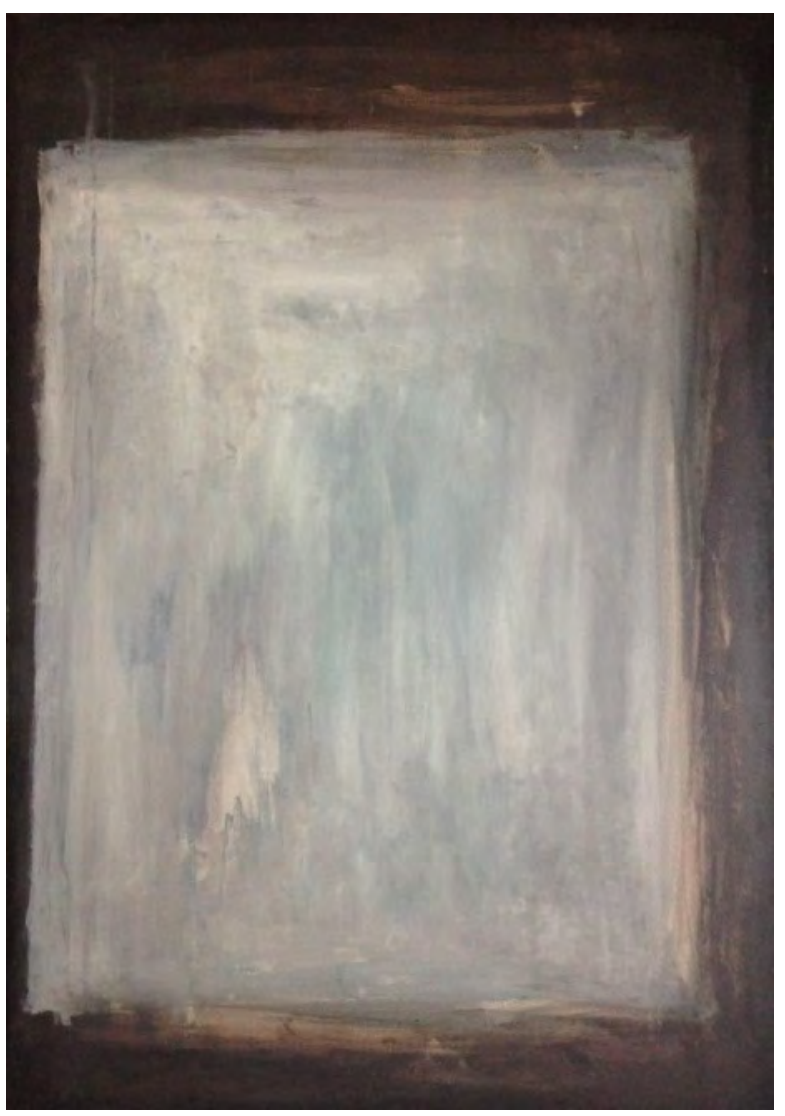

Fig. 6

Sem título, 2011

Acrílica sobre tela, $100 \times 70 \mathrm{~cm}$

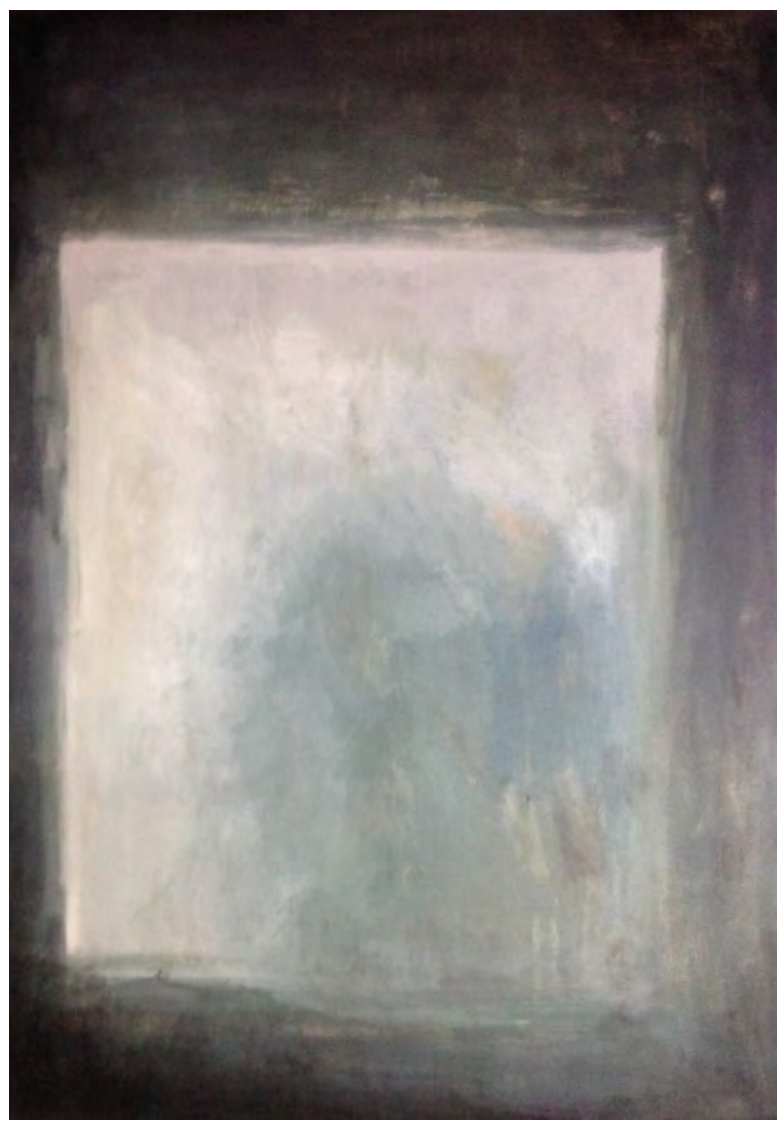

Fig. 5

Sem título, 2011

Acrílica sobre tela 100 × $70 \mathrm{~cm}$ 


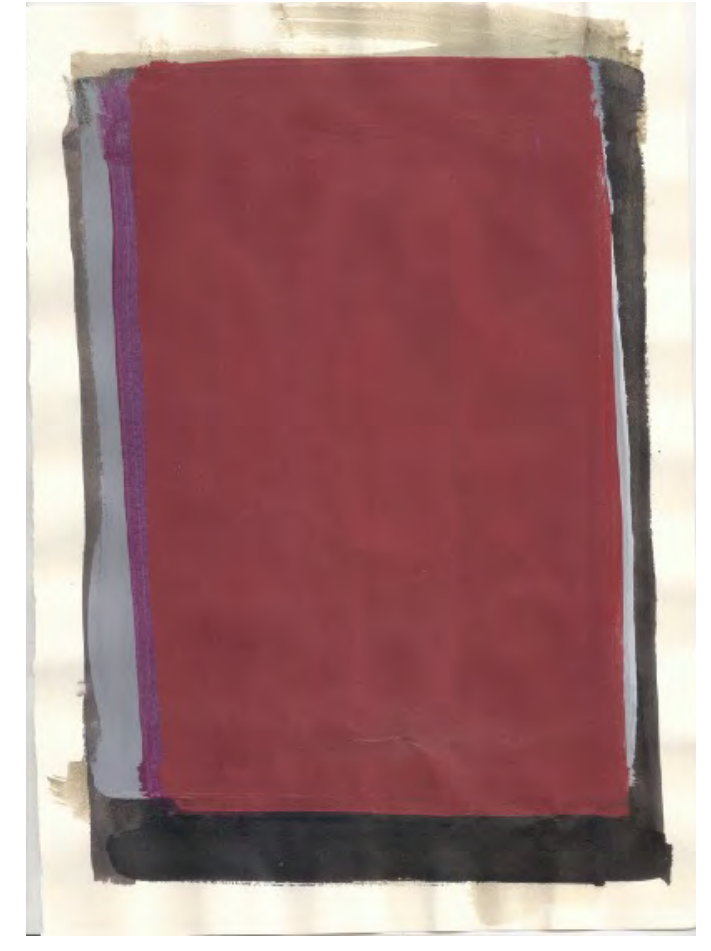

Fig. 7

Sem título, 2012

Acrílica sobre tela, $21 \times 29 \mathrm{~cm}$

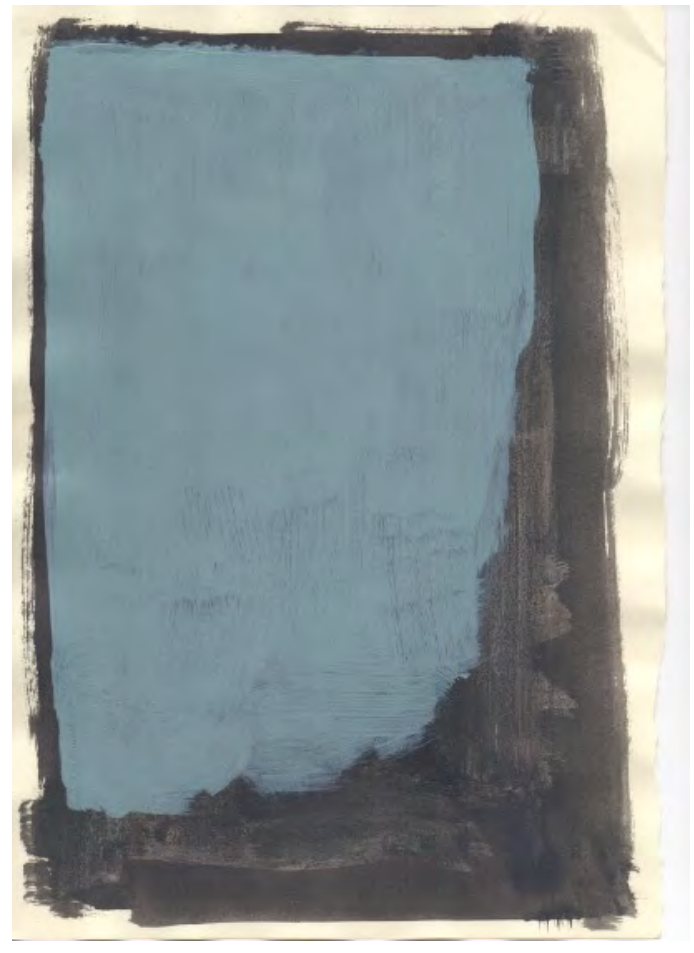

Fig. 8

Sem título, 2012

Acrílica sobre tela, $21 \times 29 \mathrm{~cm}$ 


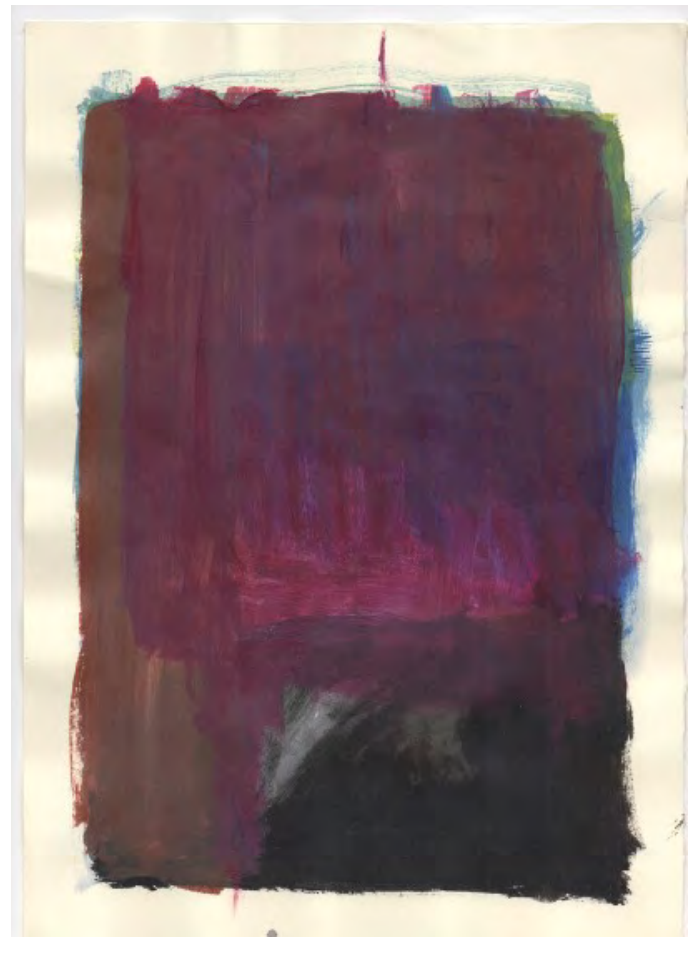

Fig. 9

Sem título, 2012

Acrílica sobre tela, $21 \times 29 \mathrm{~cm}$

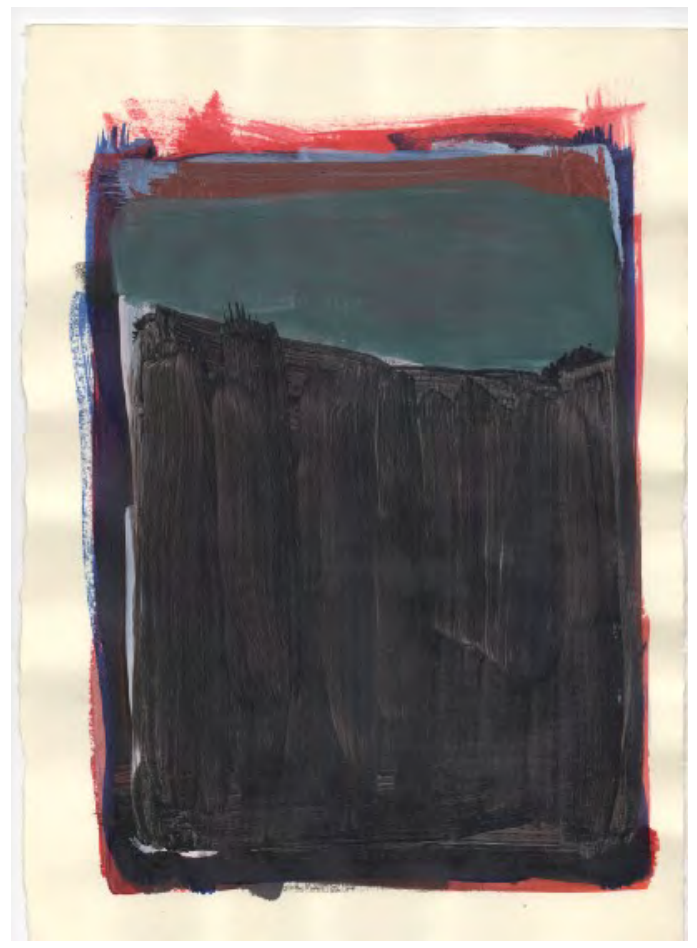

Fig. 10

Sem título, 2012

Acrílica sobre tela, $21 \times 29 \mathrm{~cm}$ 
Fig. 11

Sem título, 2012

Óleo sobre tela, 35,5 × $27 \mathrm{~cm}$

Fig. 12

Sem título, 2012

Óleo sobre tela, 35,5 × $27 \mathrm{~cm}$ 


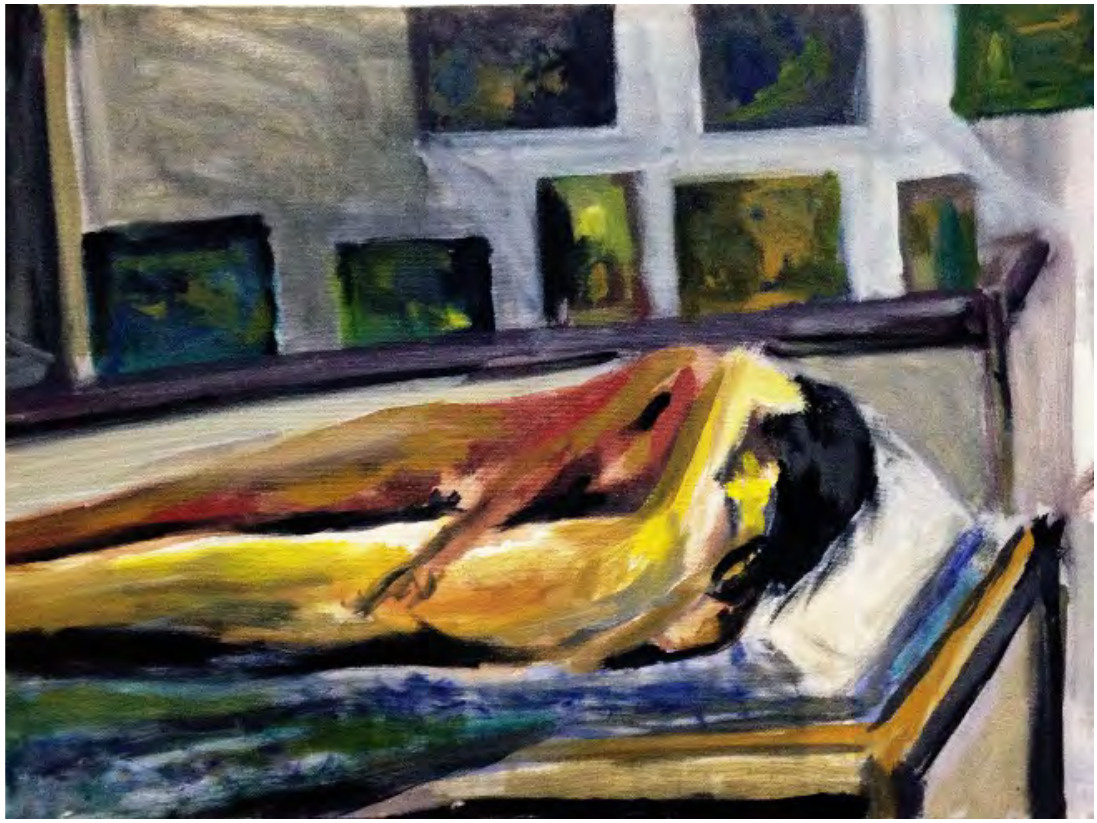

Fig. 13

Sem título, 2012

Óleo sobre tela

$35,5 \times 27 \mathrm{~cm}$

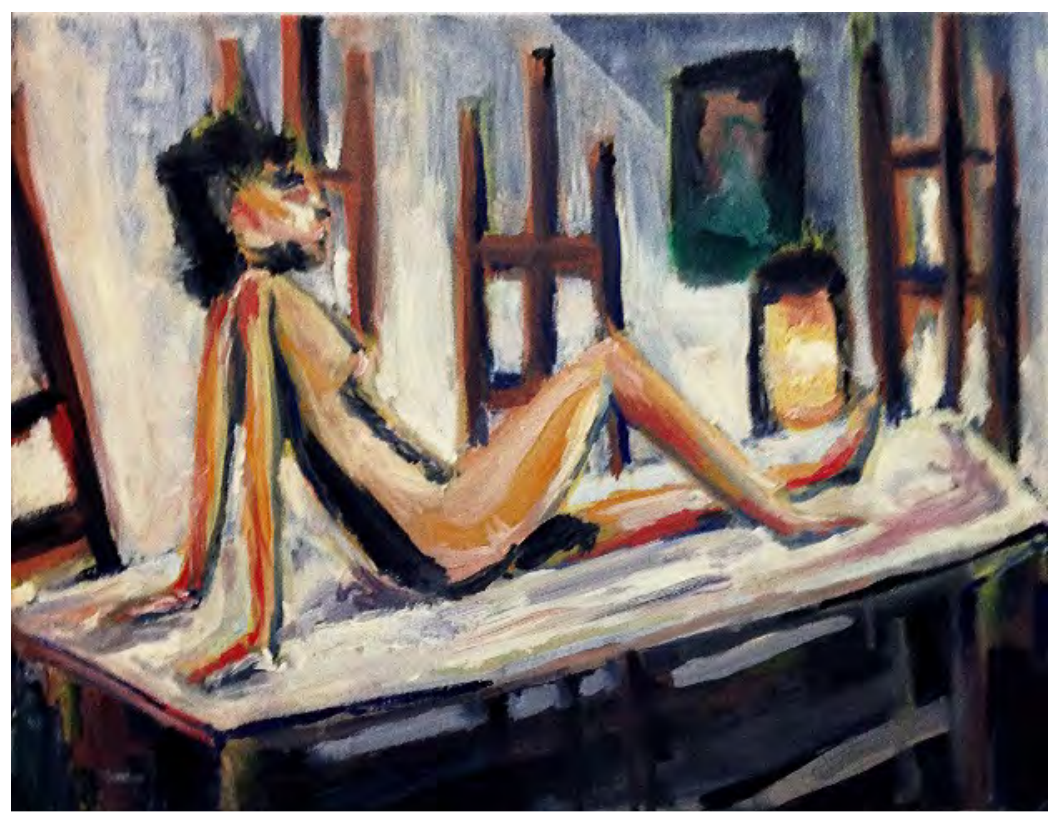

Fig. 14

Sem título, 2012

Óleo sobre tela $35,5 \times 27 \mathrm{~cm}$ 


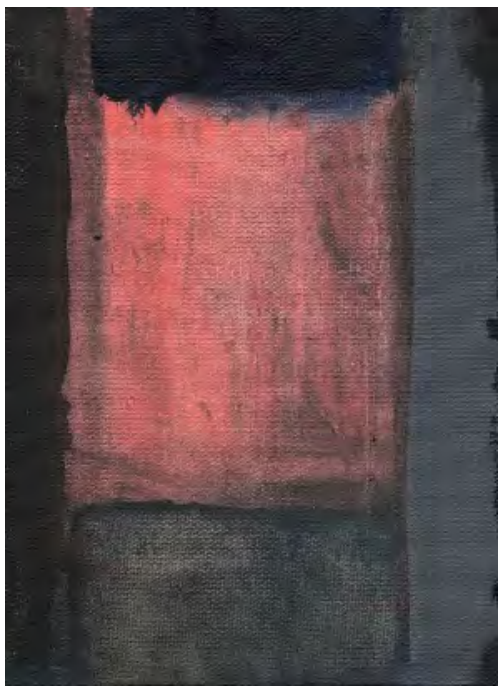

Fig. 15

Sem título, 2012

Acrílica sobre tela, $12 \times 9 \mathrm{~cm}$

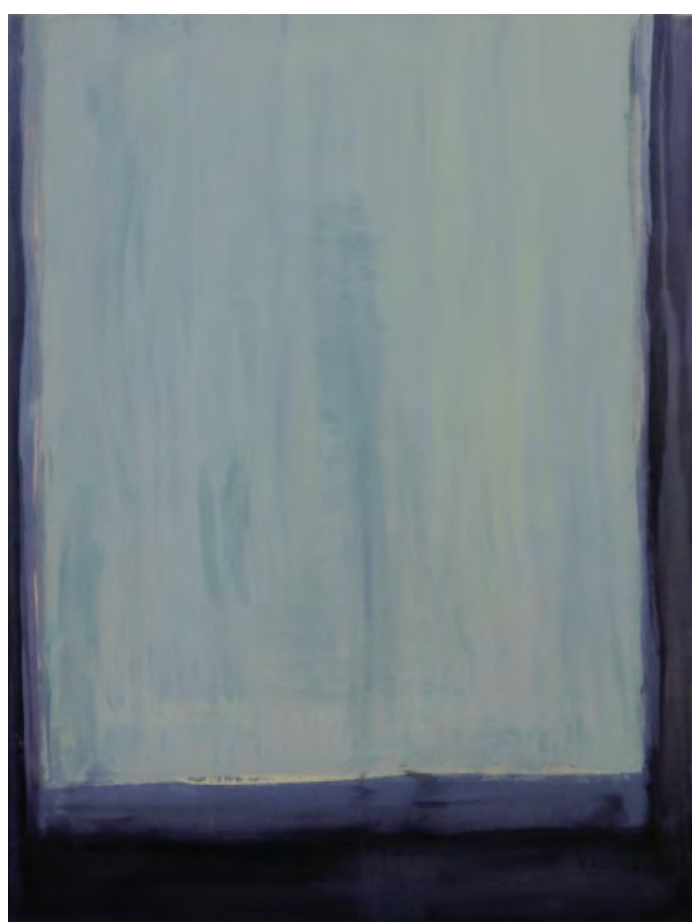

Fig. 16

Sem título, 2012

Acrílica sobre tela, 80 × $60 \mathrm{~cm}$ 


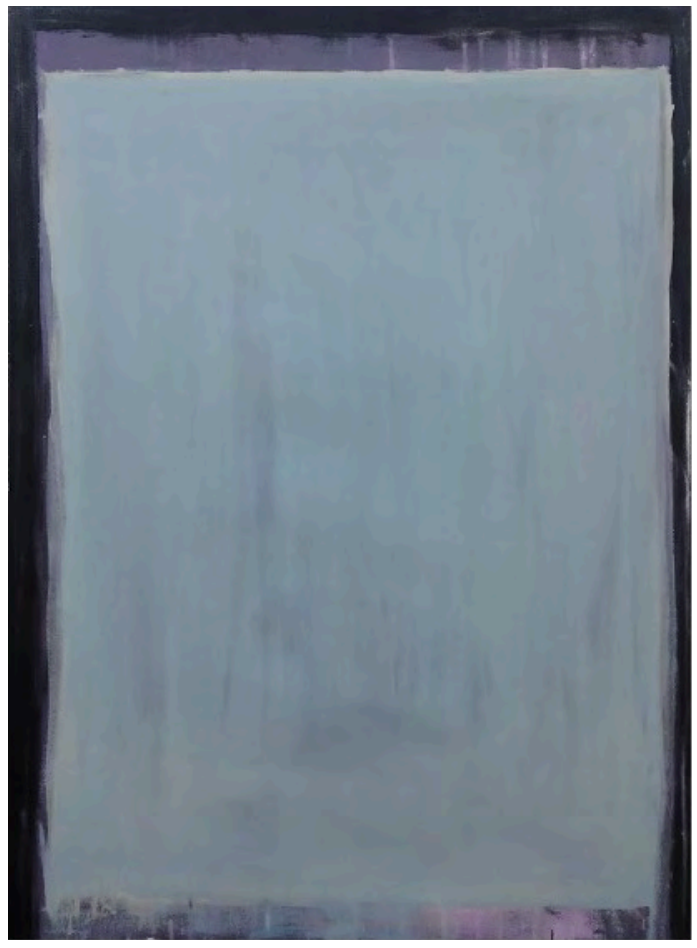

Fig. 17

Sem título, 2012

Acrílica sobre tela, $100 \times 70 \mathrm{~cm}$

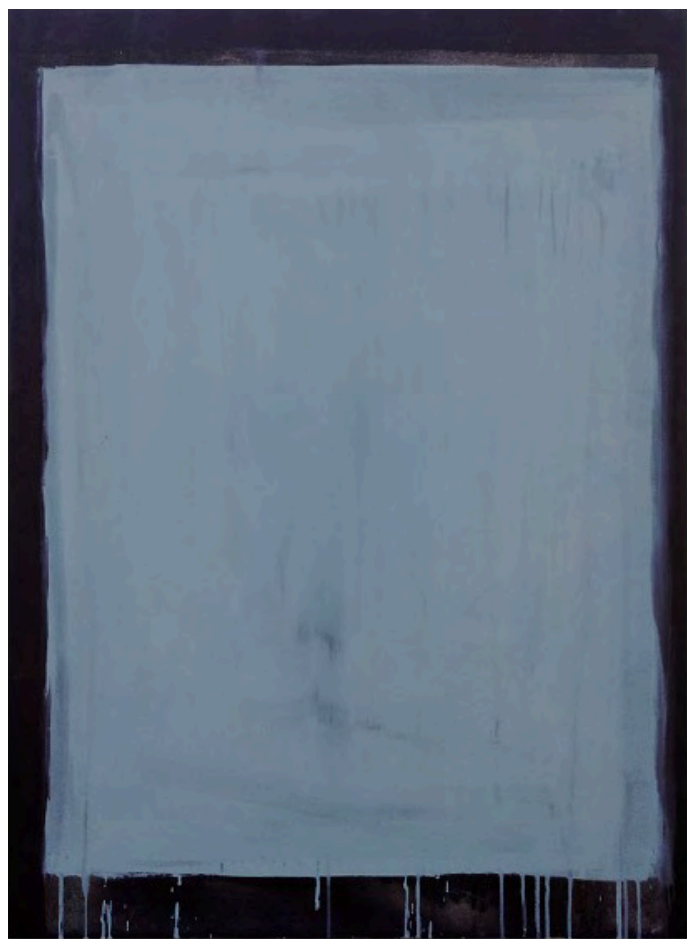

Fig. 18

Sem título, 2012

Acrílica sobre tela, $100 \times 70 \mathrm{~cm}$ 


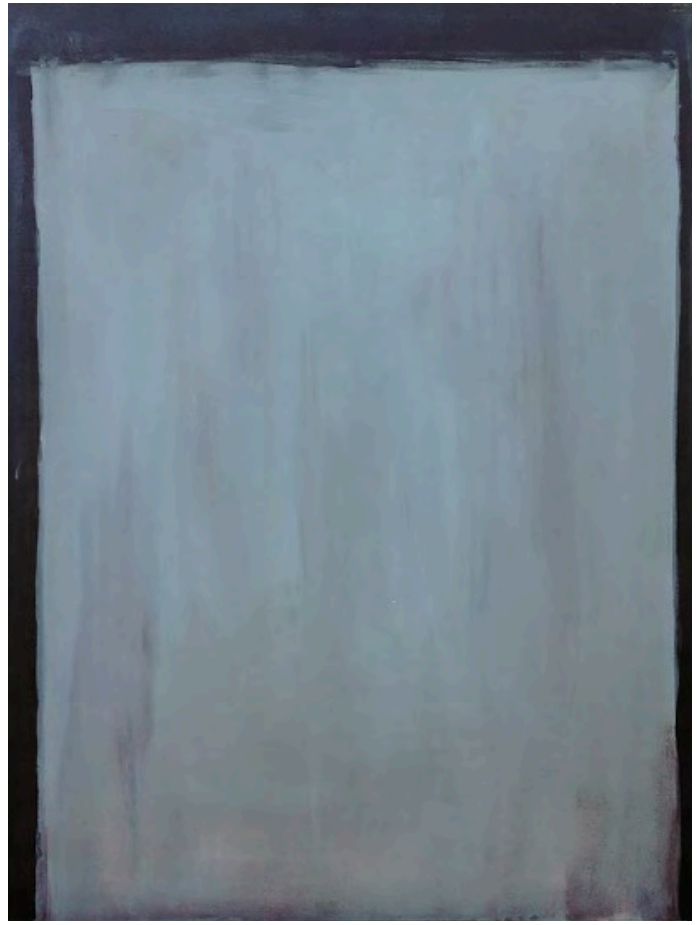

Fig. 19

Sem título, 2012

Acrílica sobre tela, $100 \times 70 \mathrm{~cm}$

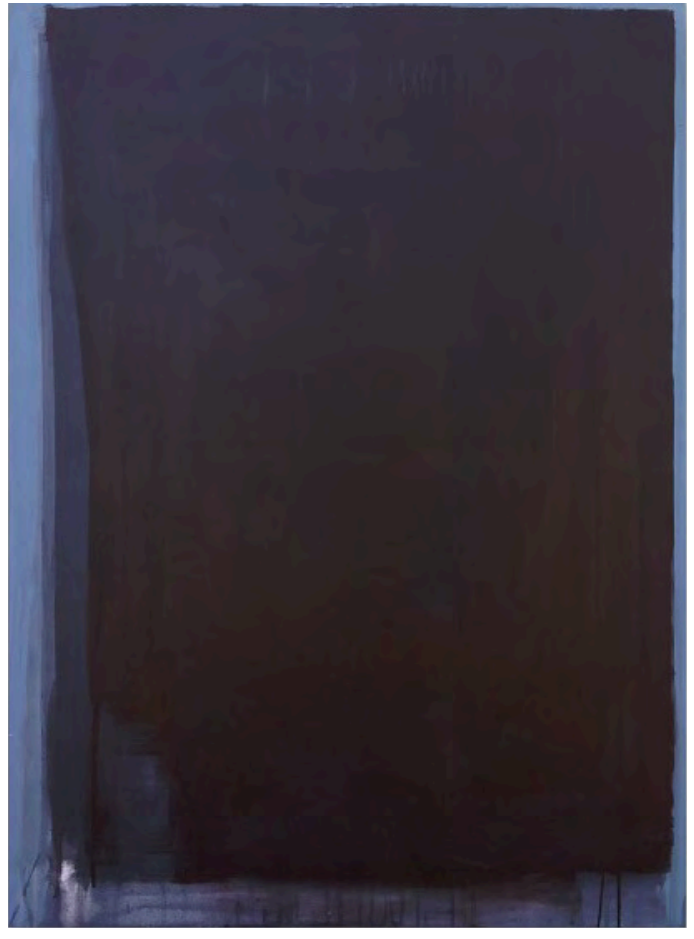

Fig. 20

Sem título, 2012

Acrílica sobre tela, $100 \times 70 \mathrm{~cm}$ 


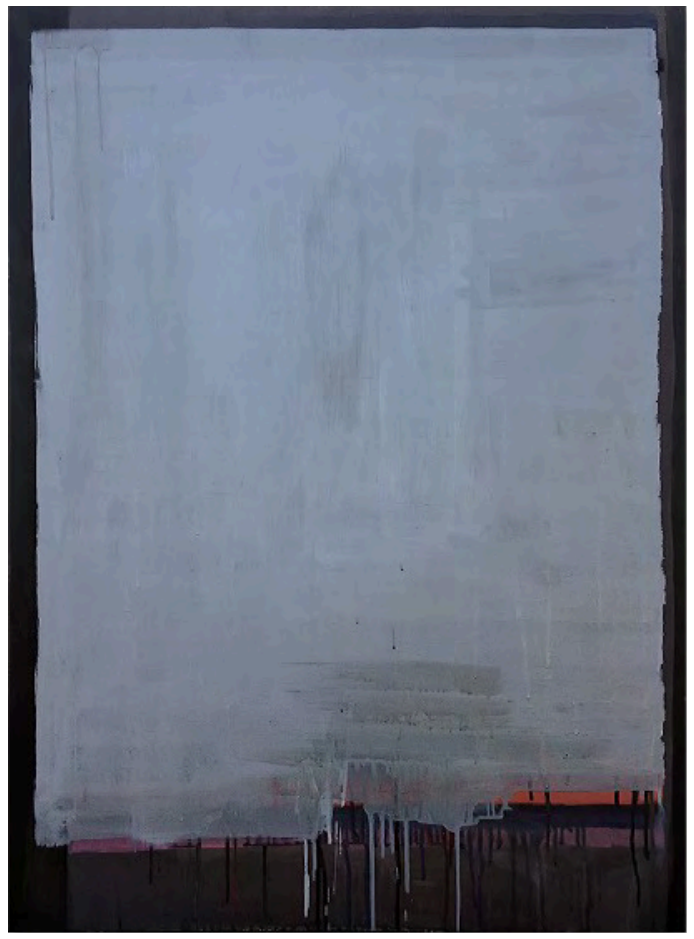

Fig. 21

Sem título, 2012

Acrílica sobre tela, $100 \times 70 \mathrm{~cm}$

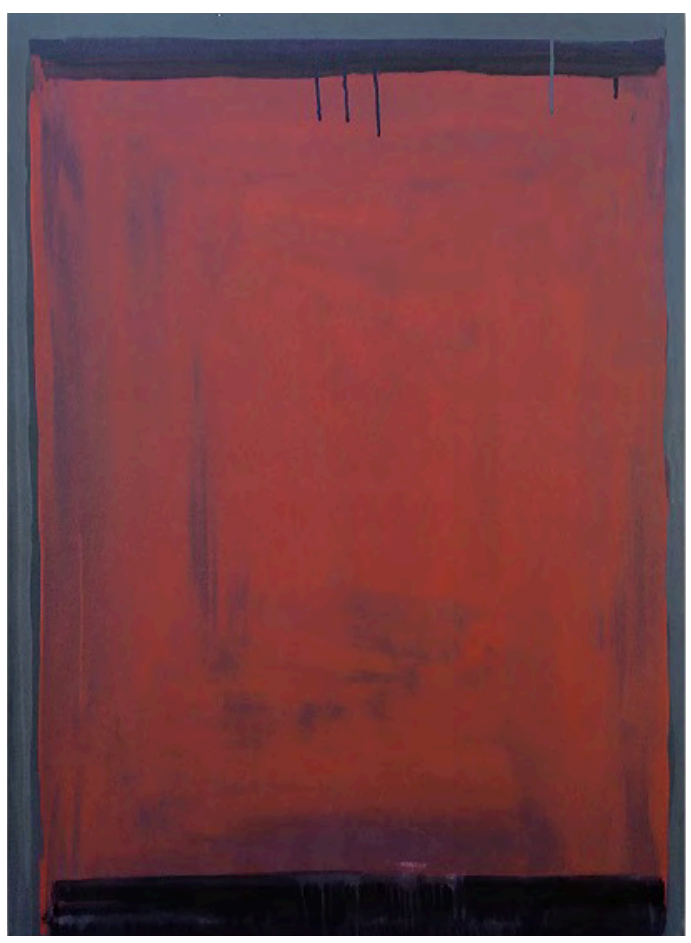

Fig. 22

Sem título, 2012

Acrílica sobre tela, $100 \times 70 \mathrm{~cm}$ 


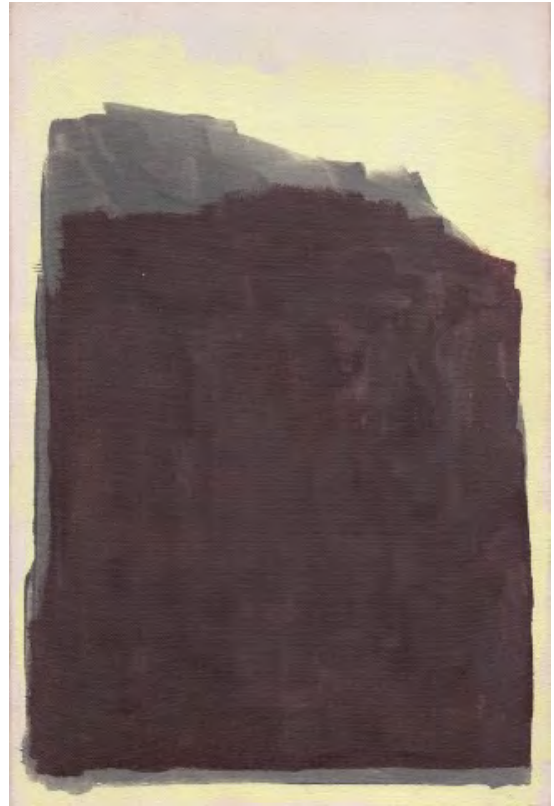

Fig. 23

Sem título, 2012

Acrílica sobre tela, $30 \times 20 \mathrm{~cm}$

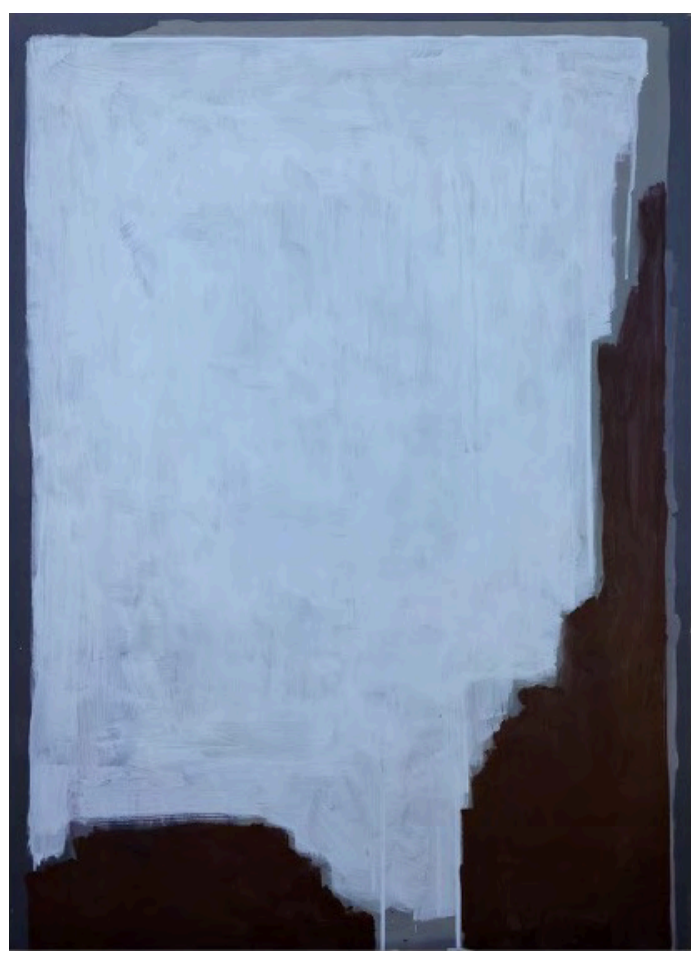

Fig. 24

Sem título, 2012

Acrílica sobre tela, $100 \times 70 \mathrm{~cm}$ 


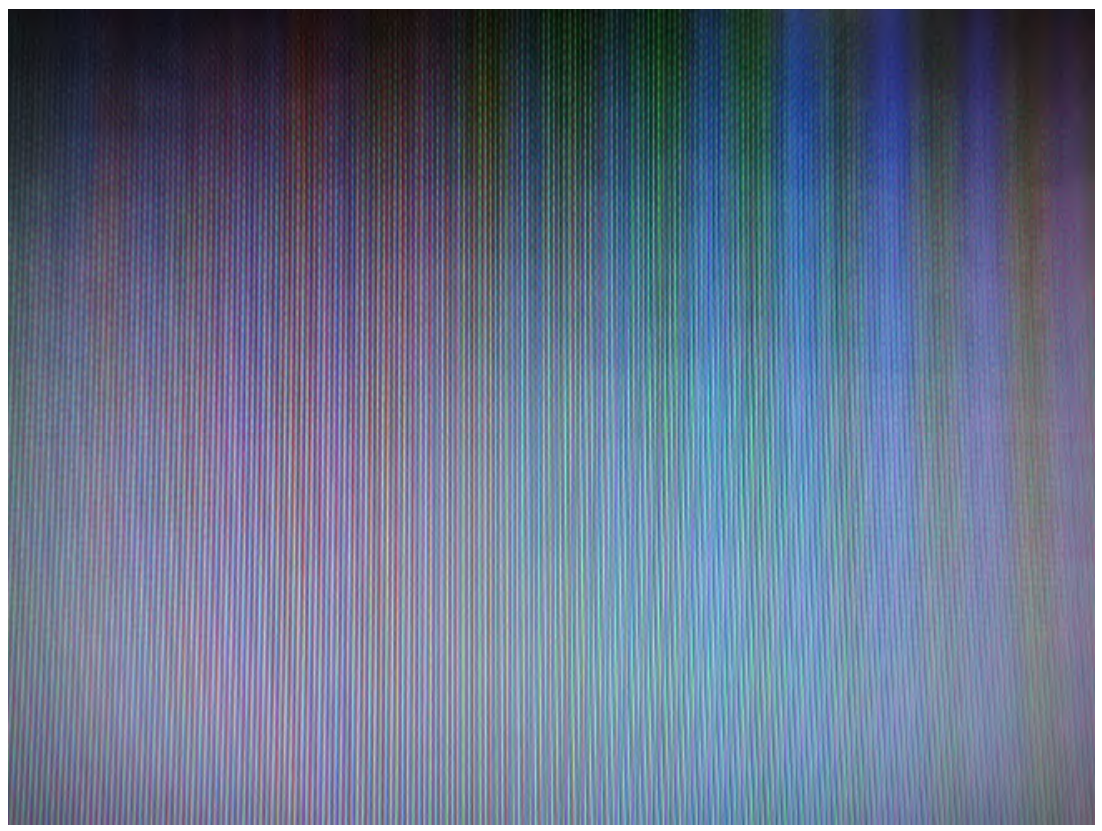

Fig. 25

Dsc01199, 2013

Fotografia digital

$12 \times 16 \mathrm{~cm}$

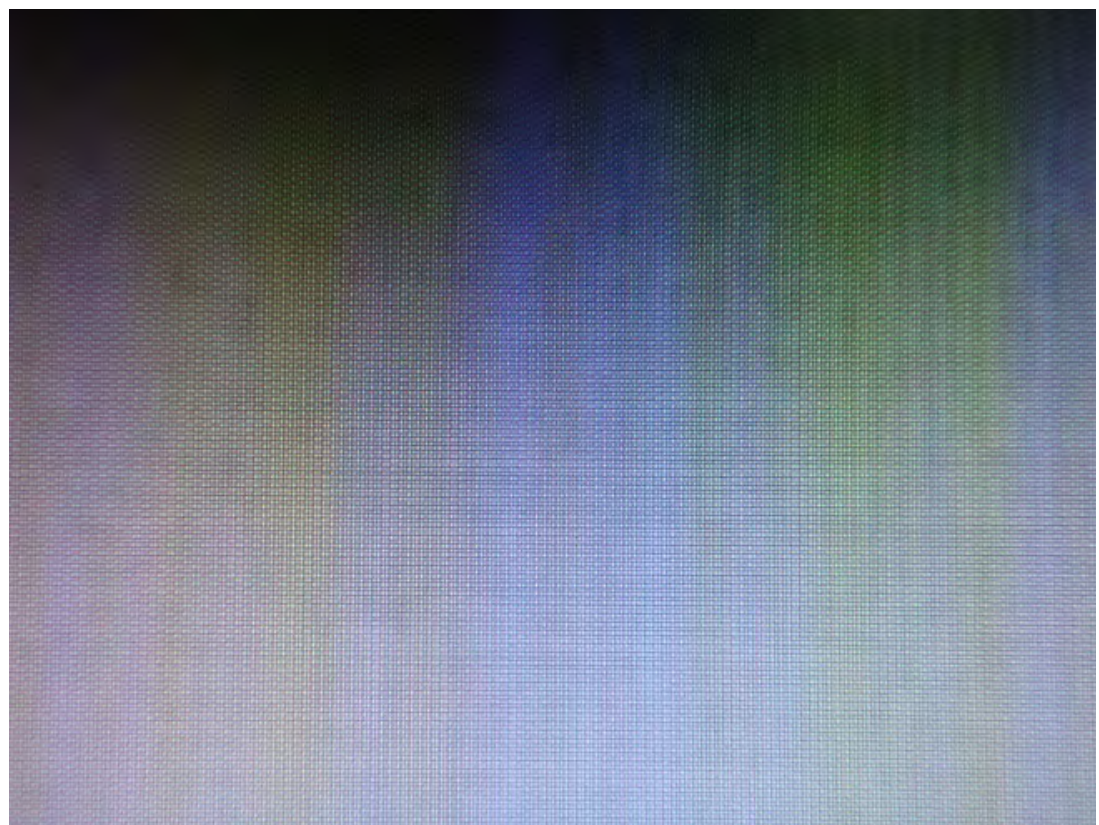

Fig. 26

Dsc01199, 2013

Fotografia digital $12 \times 16 \mathrm{~cm}$ 


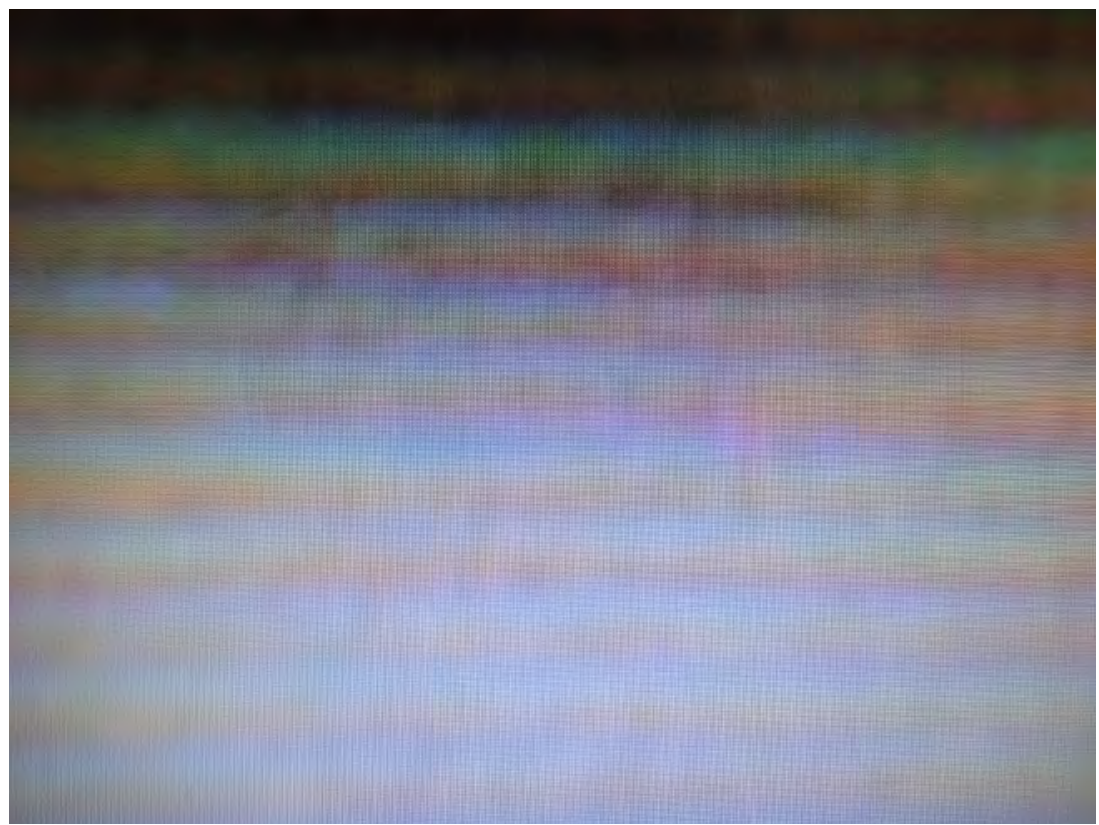

Fig. 27

Dsc01199, 2013

Fotografia digital

$12 \times 16 \mathrm{~cm}$

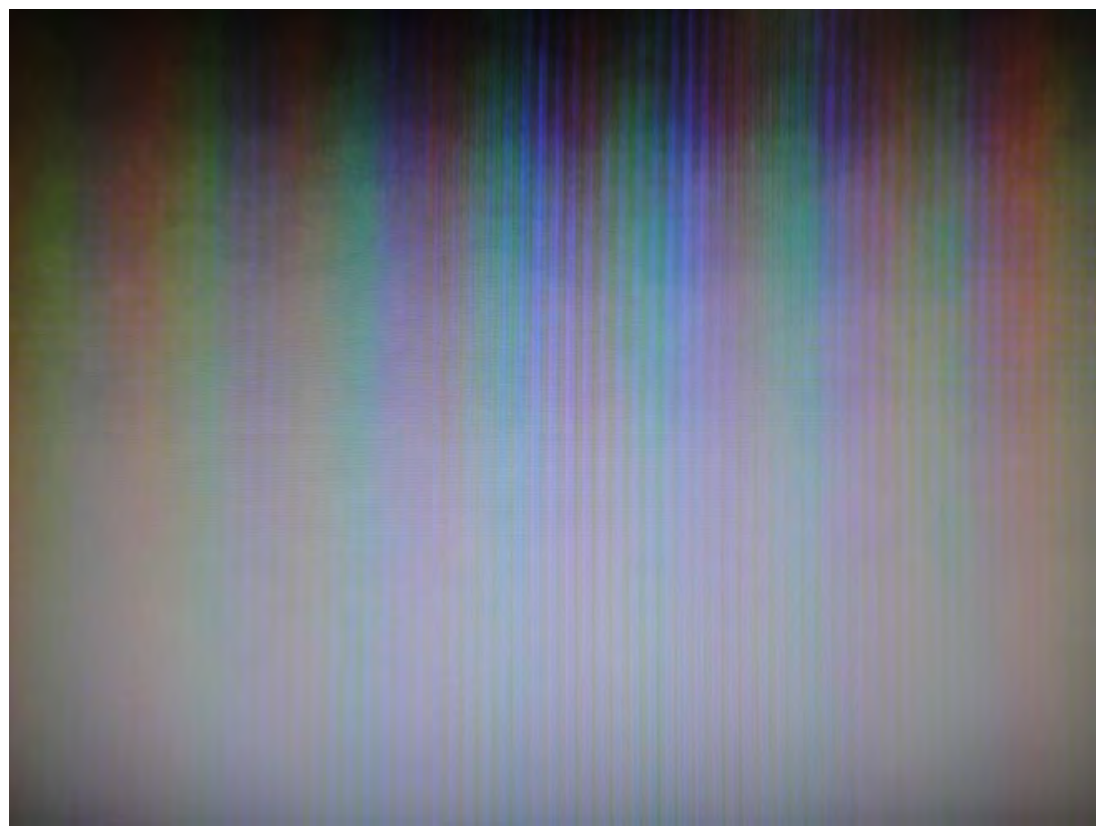

Fig. 28

Dsc01199, 2013

Fotografia digital

$12 \times 16 \mathrm{~cm}$ 

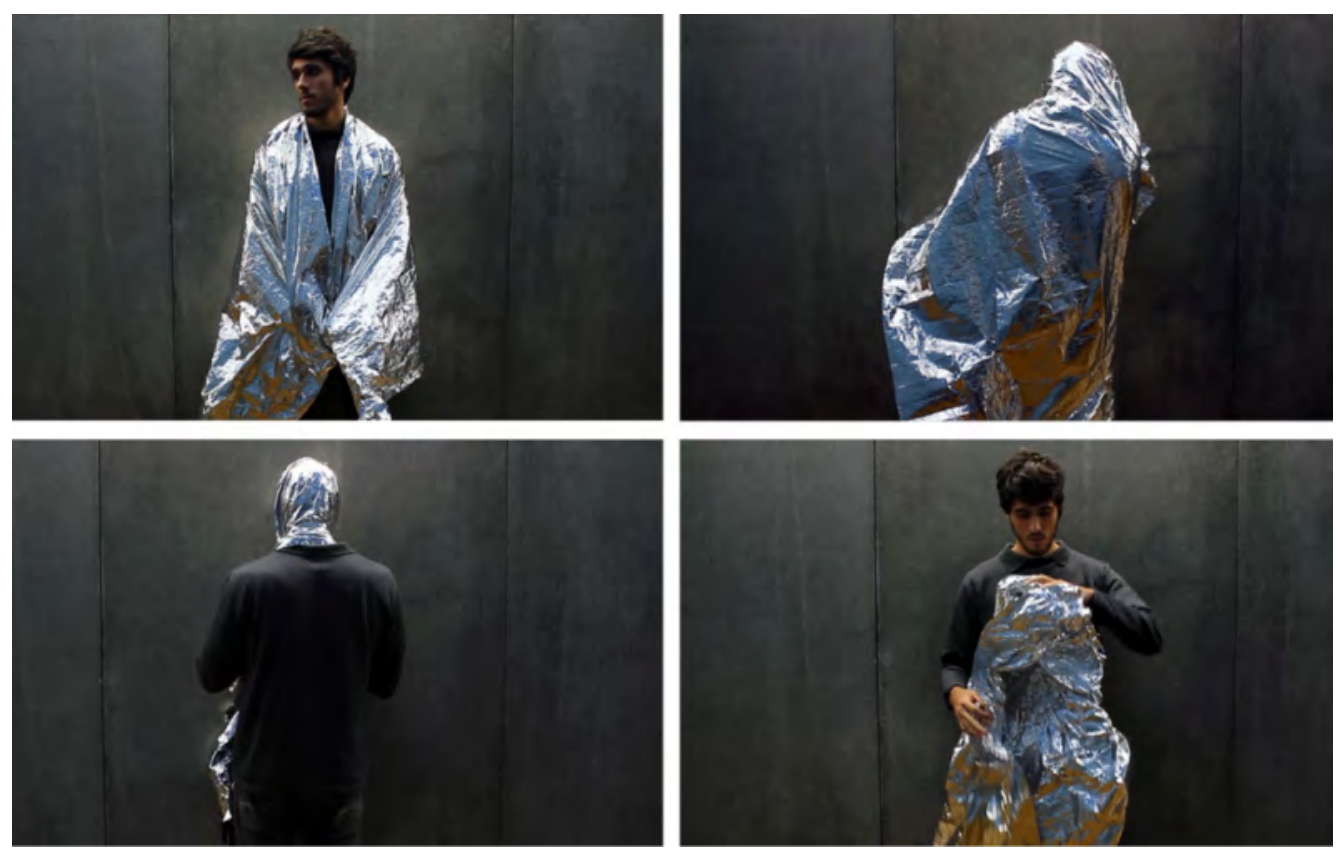

Fig. 29

Fragmento, 2013

FAU-USP, Performance, 8'48"
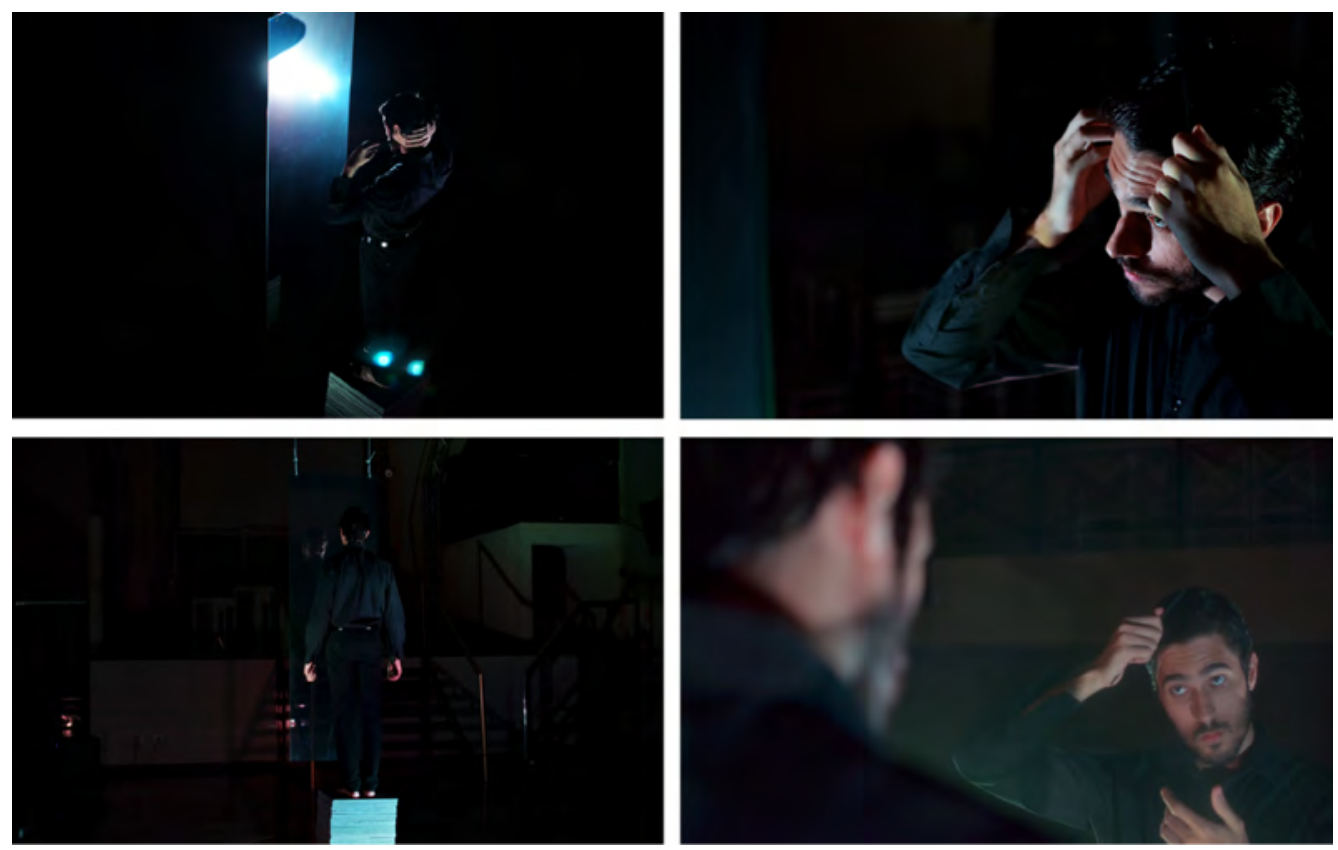

Fig. 30

Flutuações, 2013

Espaço Paulista, Performance, 9'11" 


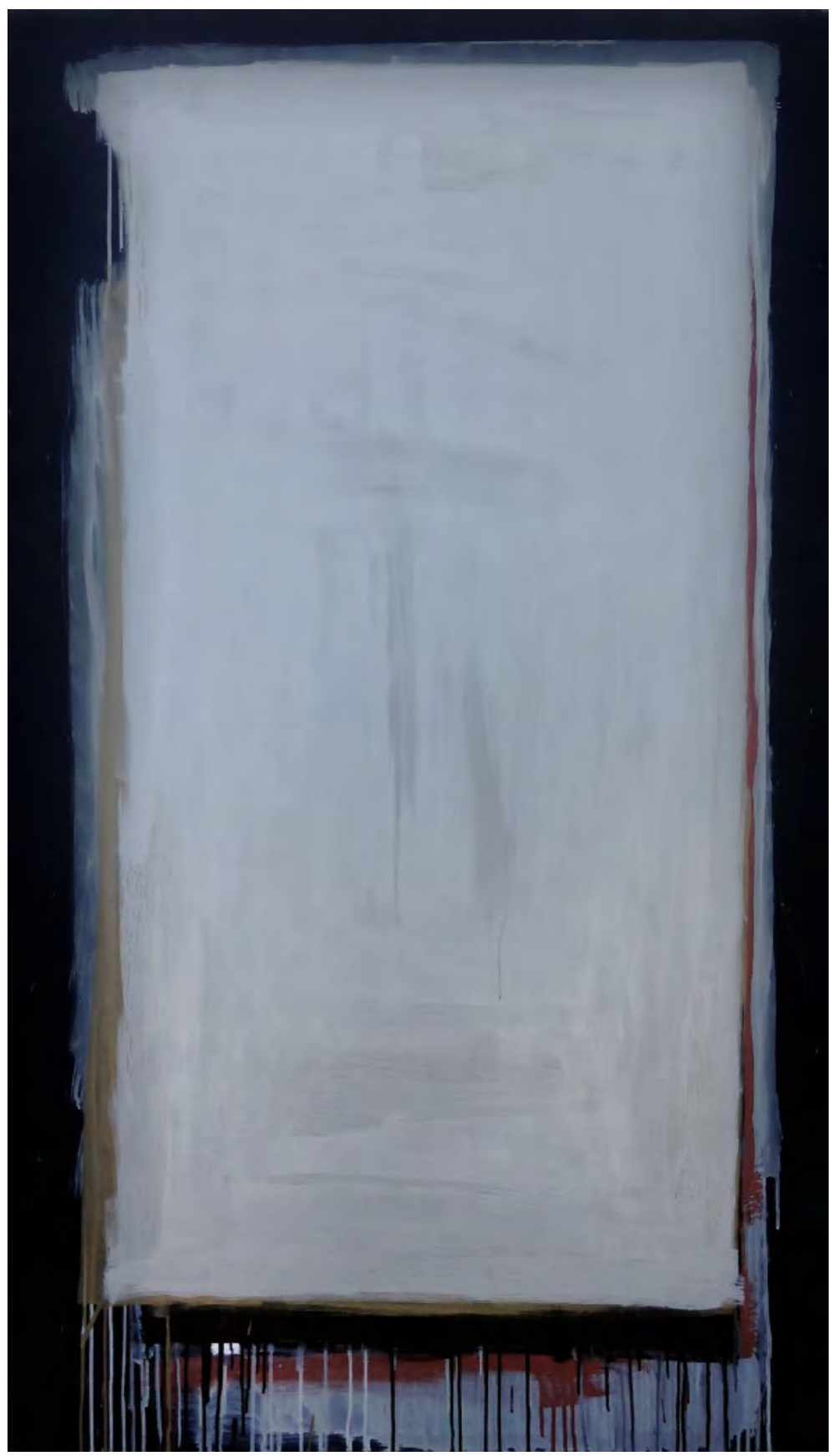

Fig. 31

Sem título, 2014

Óleo sobre tela

$170 \times 100 \mathrm{~cm}$ 


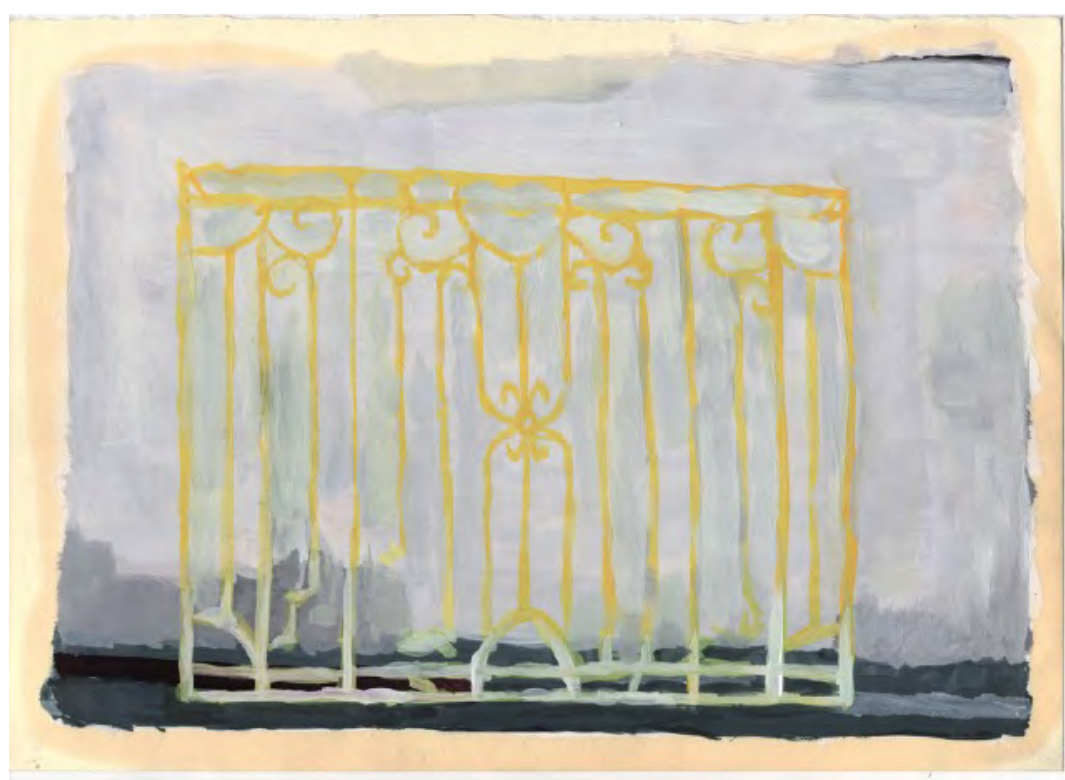

Fig. 32

Sem título, 2014 Óleo sobre papel, $21 \times 29 \mathrm{~cm}$

Fig. 33

Sem título, 2014 Óleo sobre papel $29 \times 21 \mathrm{~cm}$ 

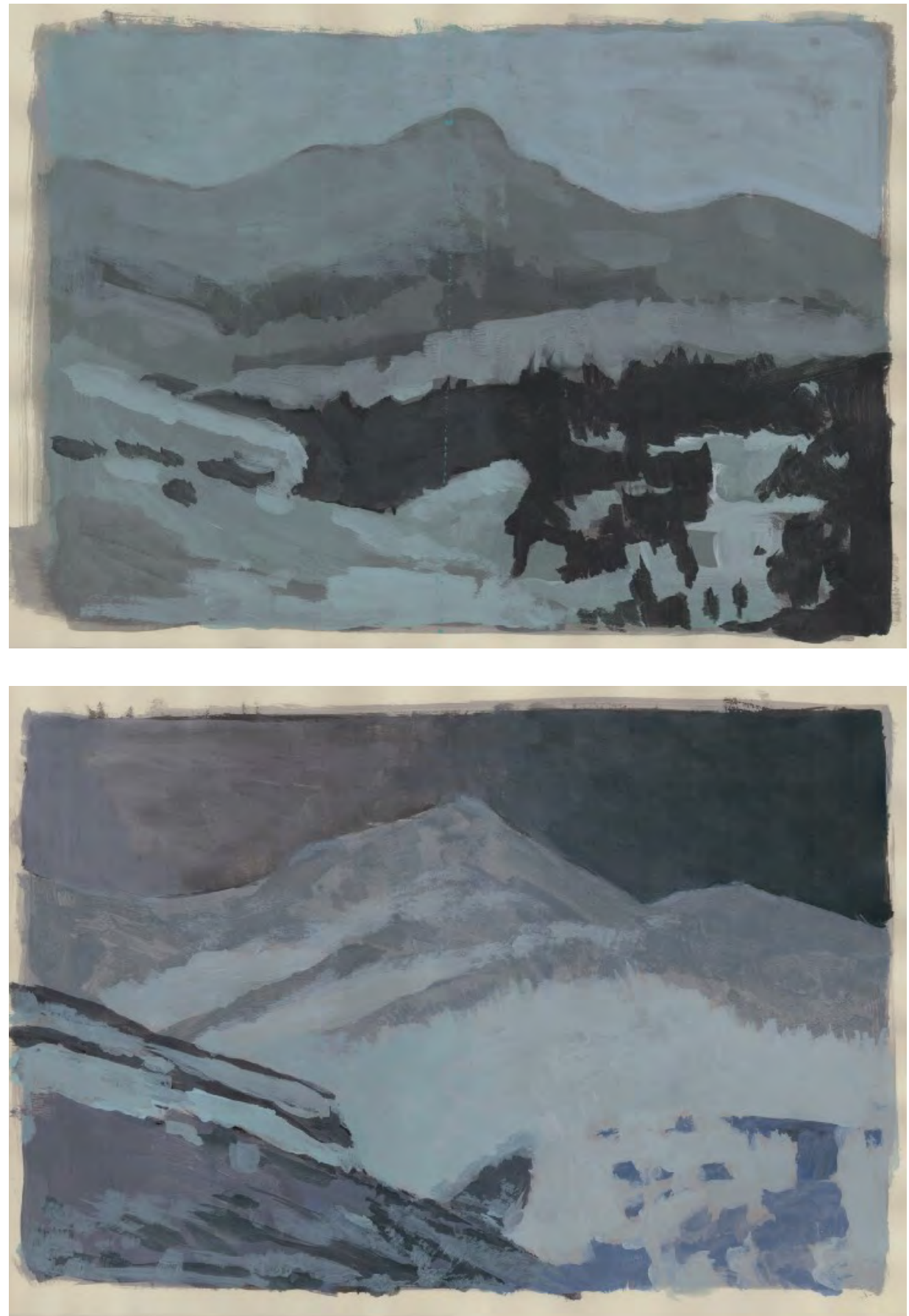

Fig. 34

Sem título, 2014

Óleo sobre papel, 29 × $21 \mathrm{~cm}$ cada 


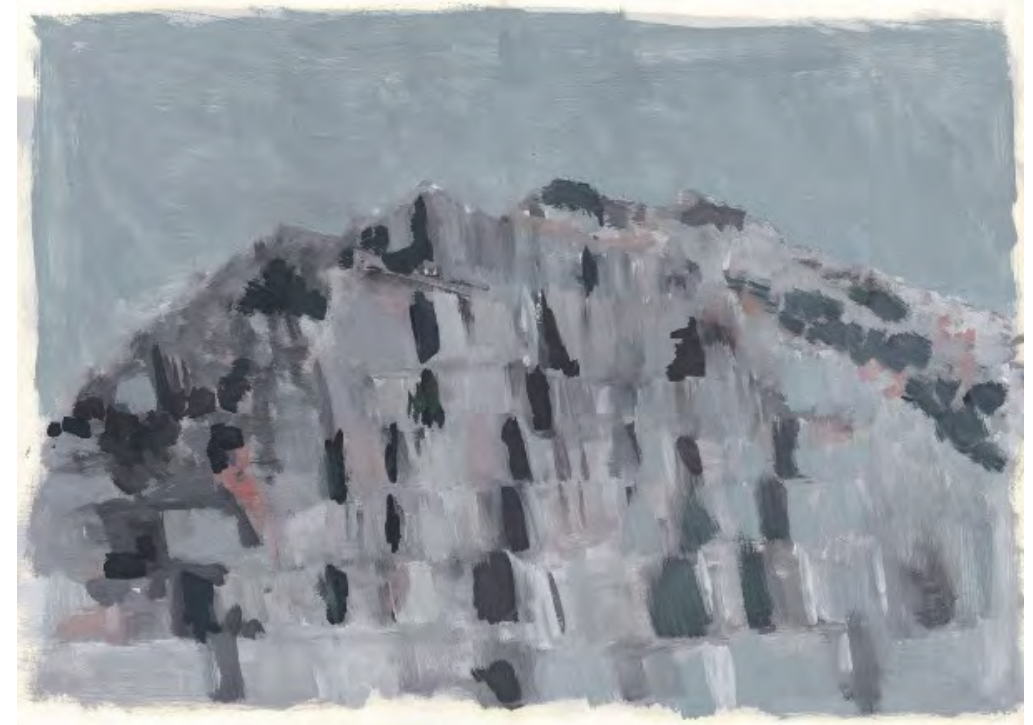

Fig. 35

Sem título, 2014

Óleo sobre papel

$21 \times 29 \mathrm{~cm}$

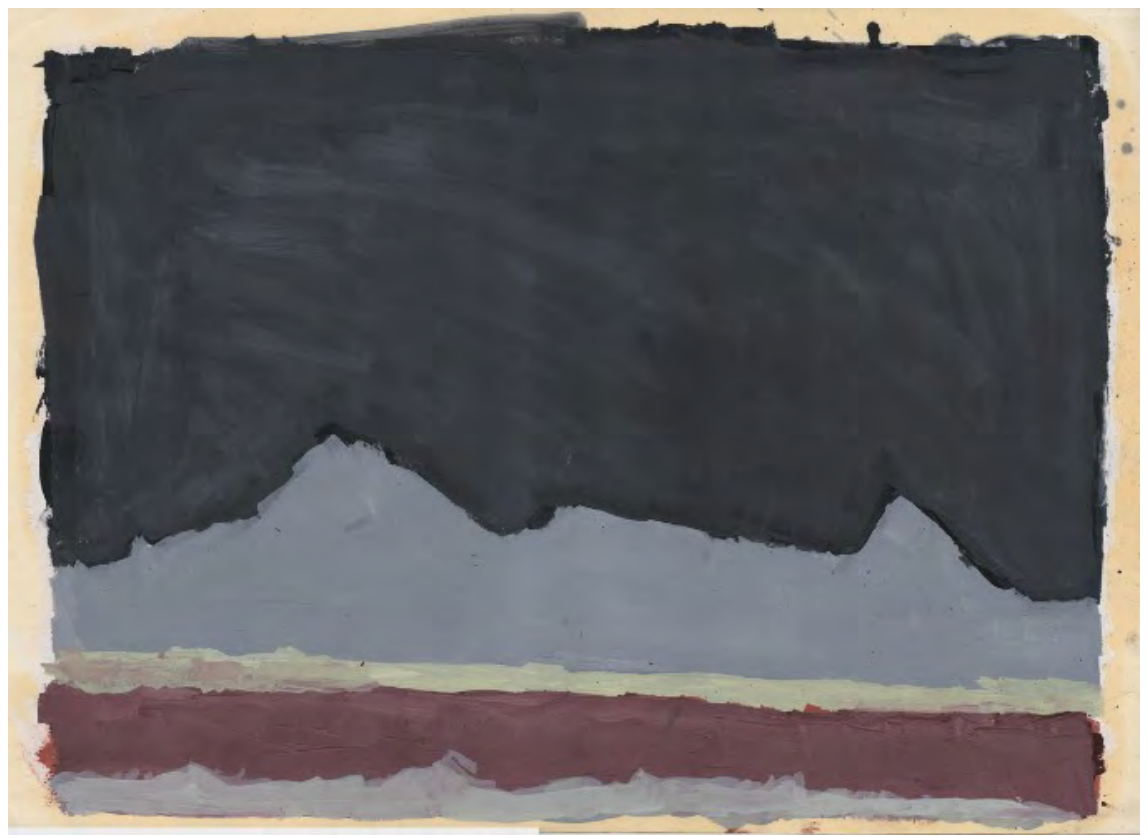

Fig. 36

Sem título, 2014

Óleo sobre papel $29 \times 42 \mathrm{~cm}$ 


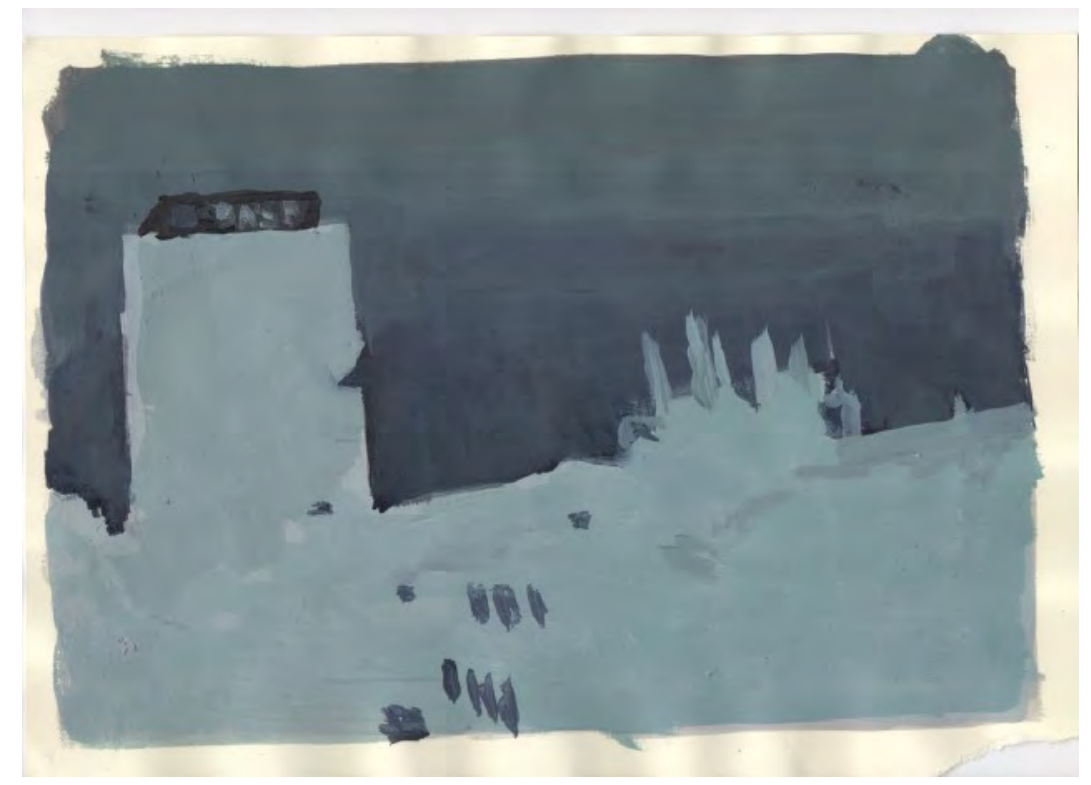

Fig. 37

BASF, 2014

Óleo sobre papel $29 \times 21 \mathrm{~cm}$

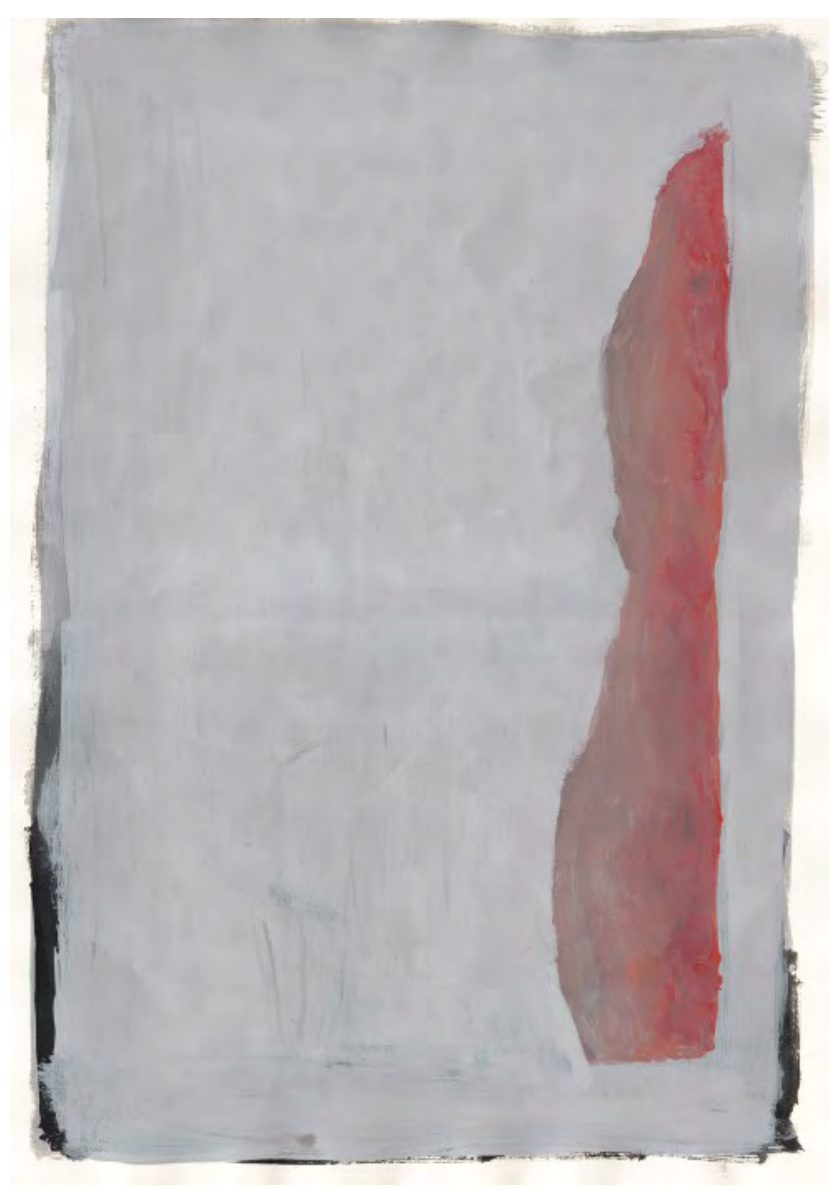

Fig. 38

Caco, 2014

Óleo sobre papel $42 \times 29 \mathrm{~cm}$ 


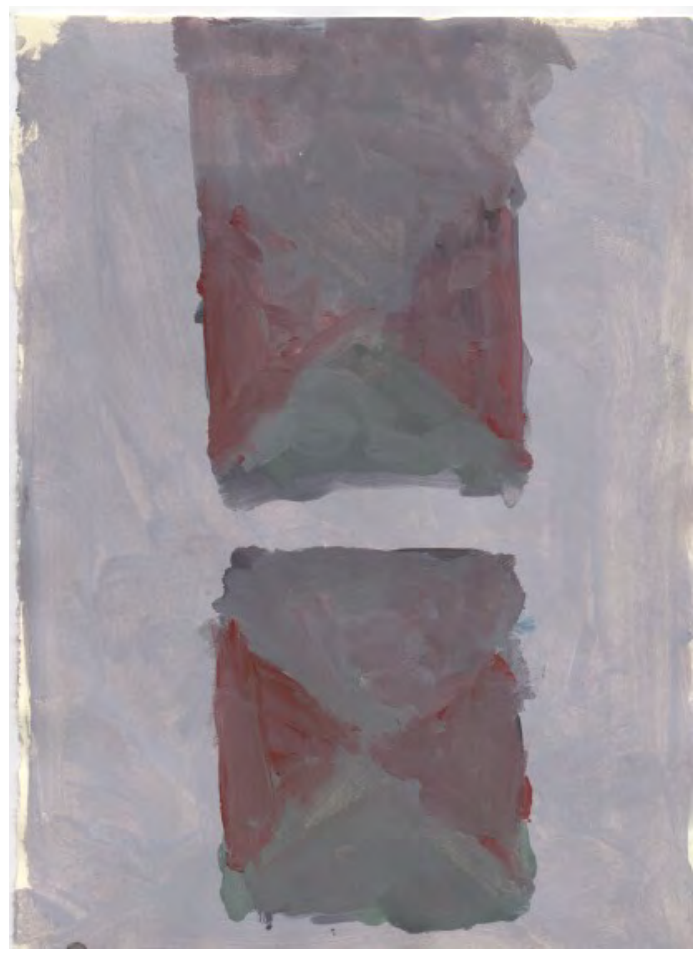

Fig. 39

Sem título, 2014

Óleo sobre papel, 29 × $21 \mathrm{~cm}$

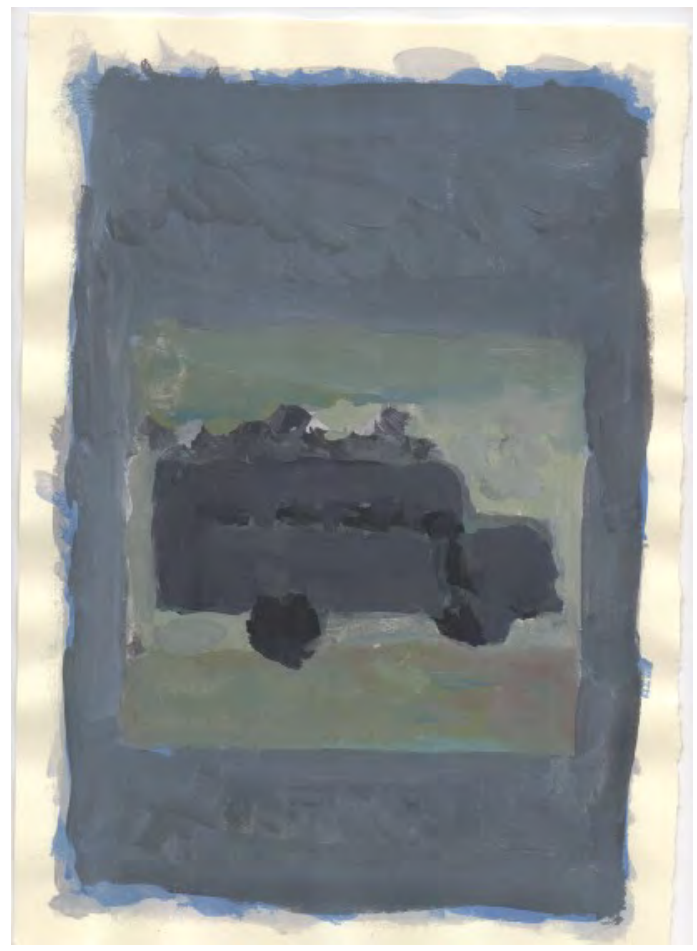

Fig. 40

Sem título, 2014

Óleo sobre papel, 29 × $21 \mathrm{~cm}$ 


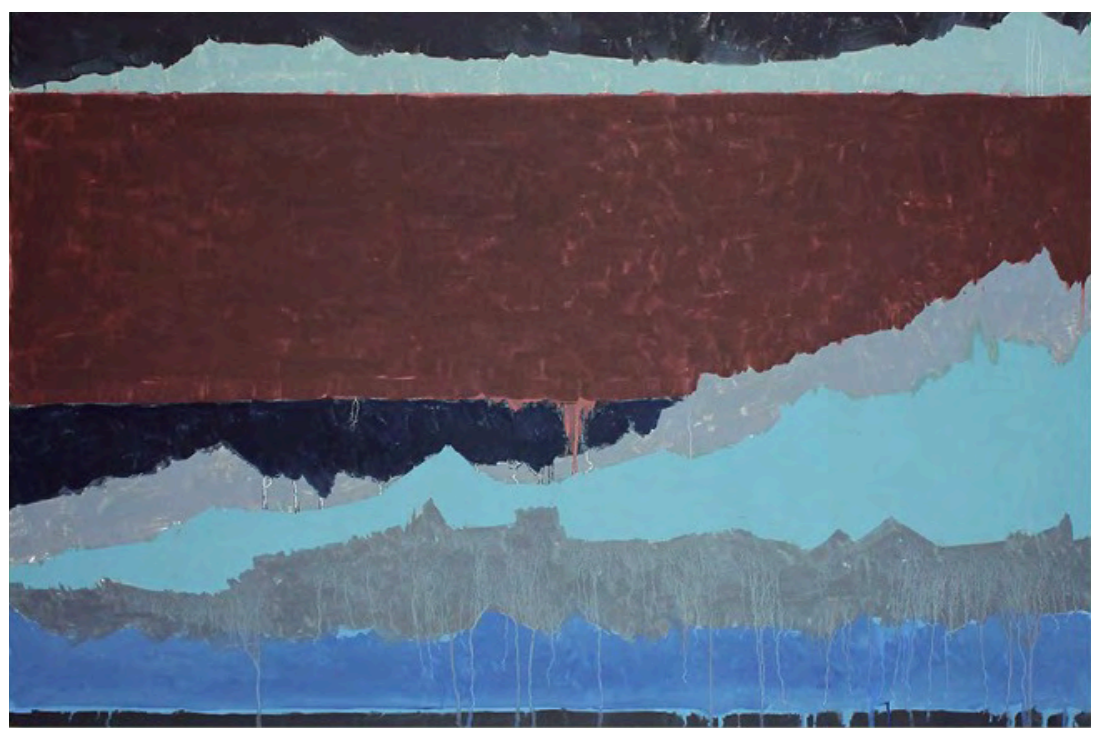

Fig. 41

Sem título, 2014 Óleo sobre tela $60 \times 90 \mathrm{~cm}$

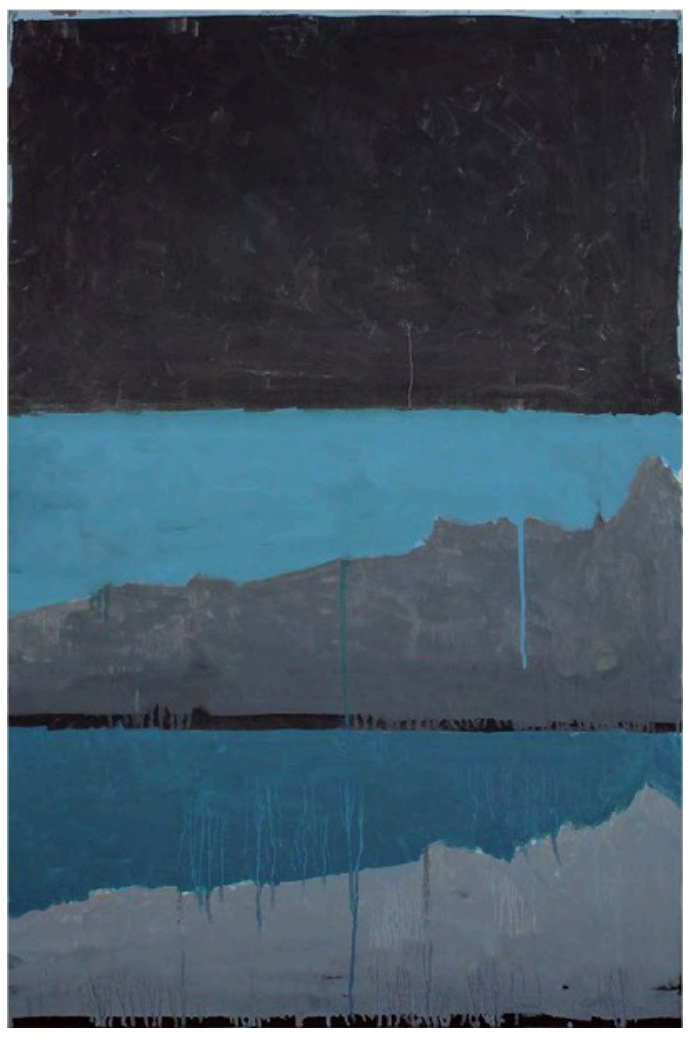

Fig. 42

Sem título, 2014 Óleo sobre tela $90 \times 60 \mathrm{~cm}$ 

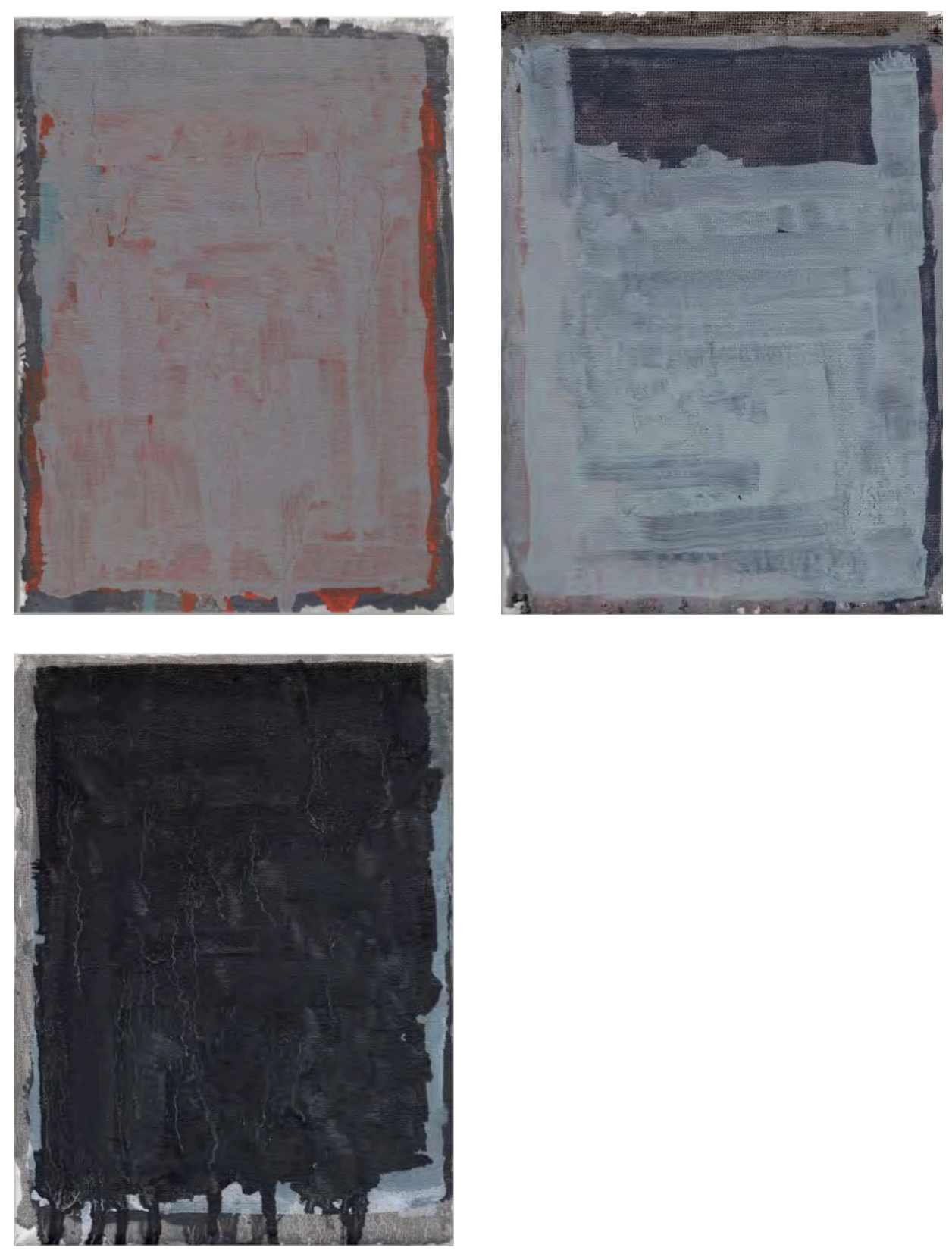

Fig. 43

Sem título, 2015

Óleo sobre tela, 18 x 12,5 cm cada 


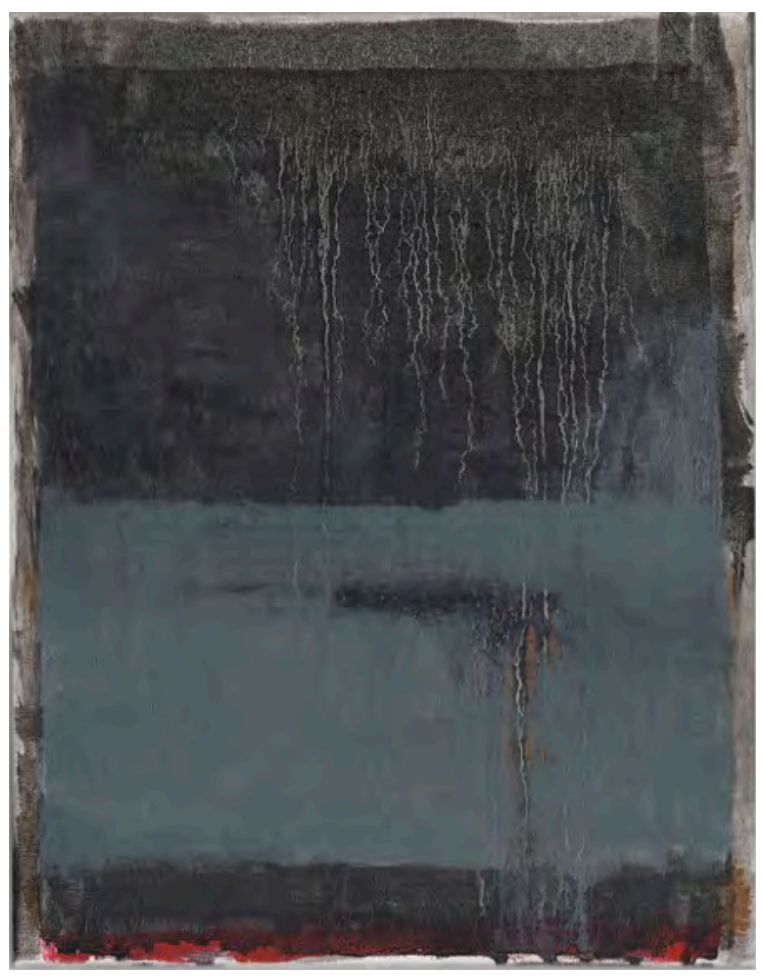

Fig. 44

Sem título, 2015

Óleo sobre tela, 30 × $24 \mathrm{~cm}$

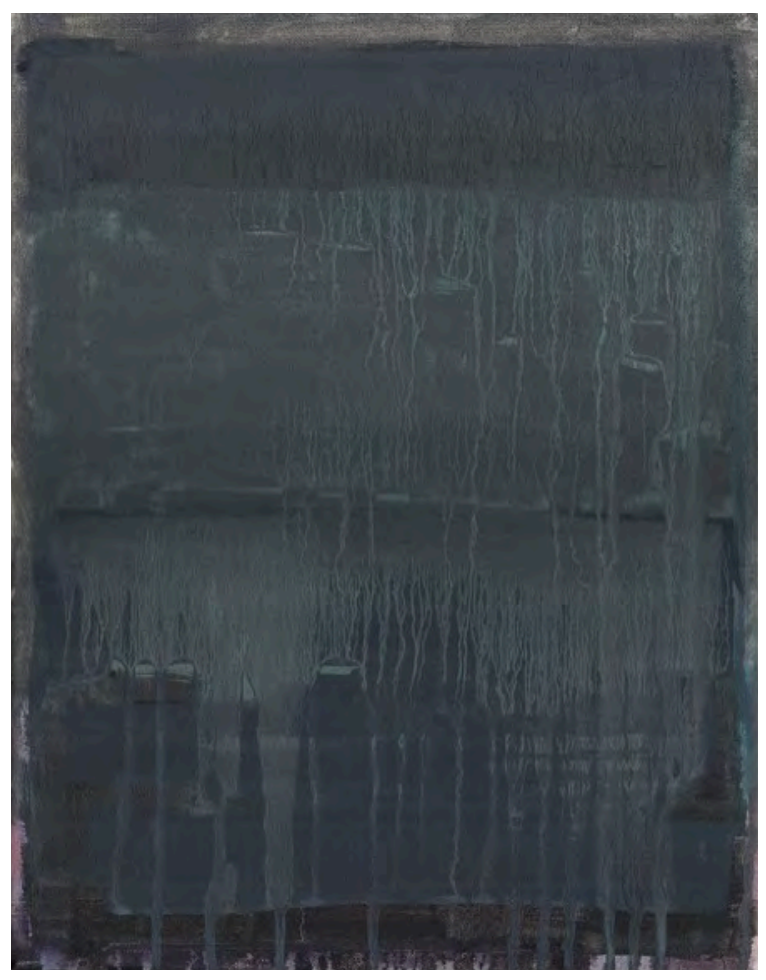

Fig. 45

Sem título, 2015

Óleo sobre tela 30 × 24 cm 


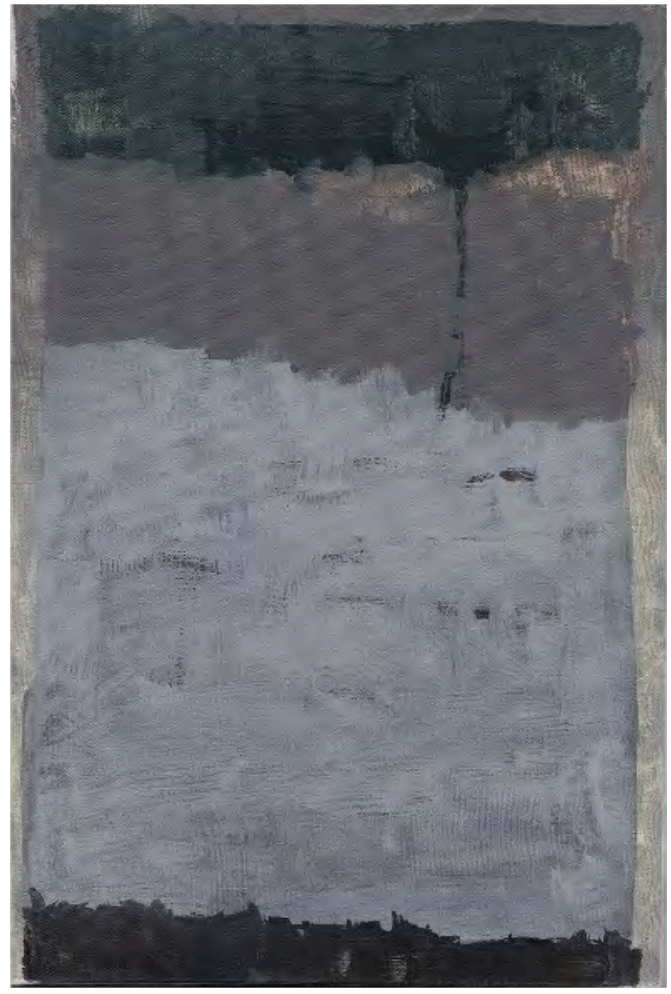

Fig. 46

Sem título, 2015

Óleo sobre tela, $30 \times 20 \mathrm{~cm}$

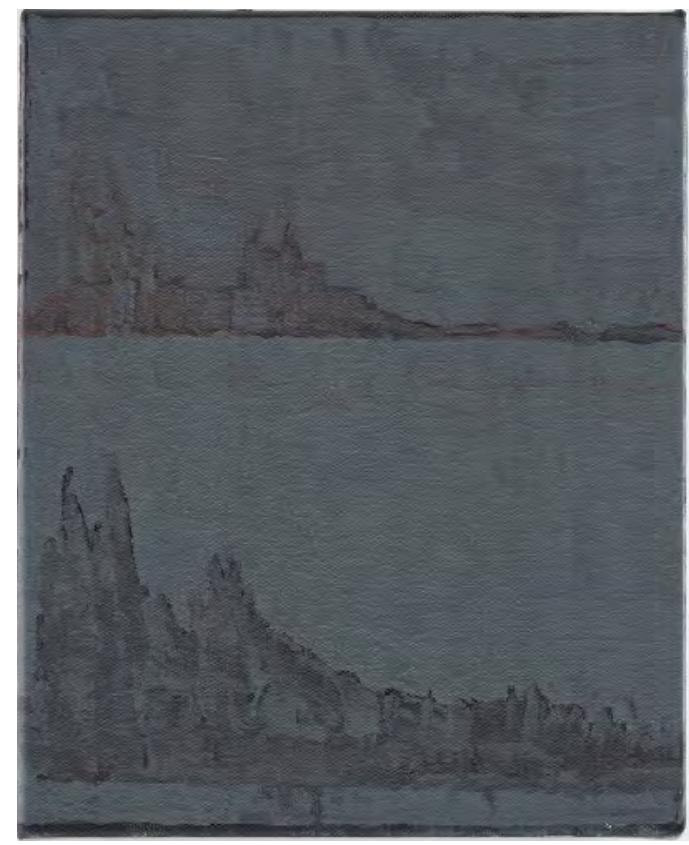

Fig. 47

Sem título, 2016

Óleo sobre tela, 25 × $20 \mathrm{~cm}$ 


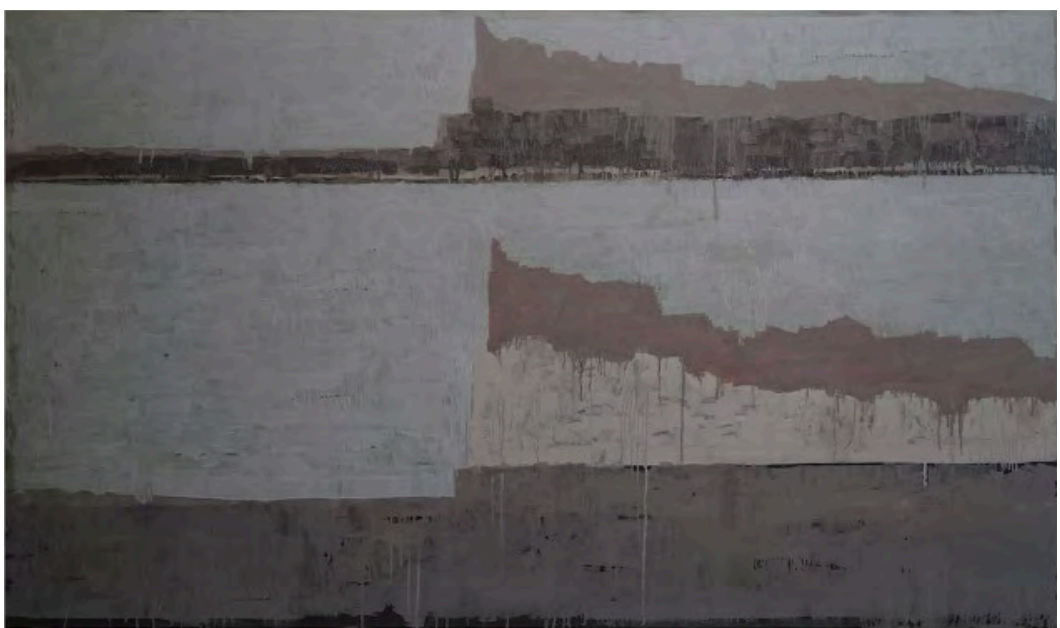

Fig. 48

Sem título, 2016

Óleo sobre tela $100 \times 170 \mathrm{~cm}$

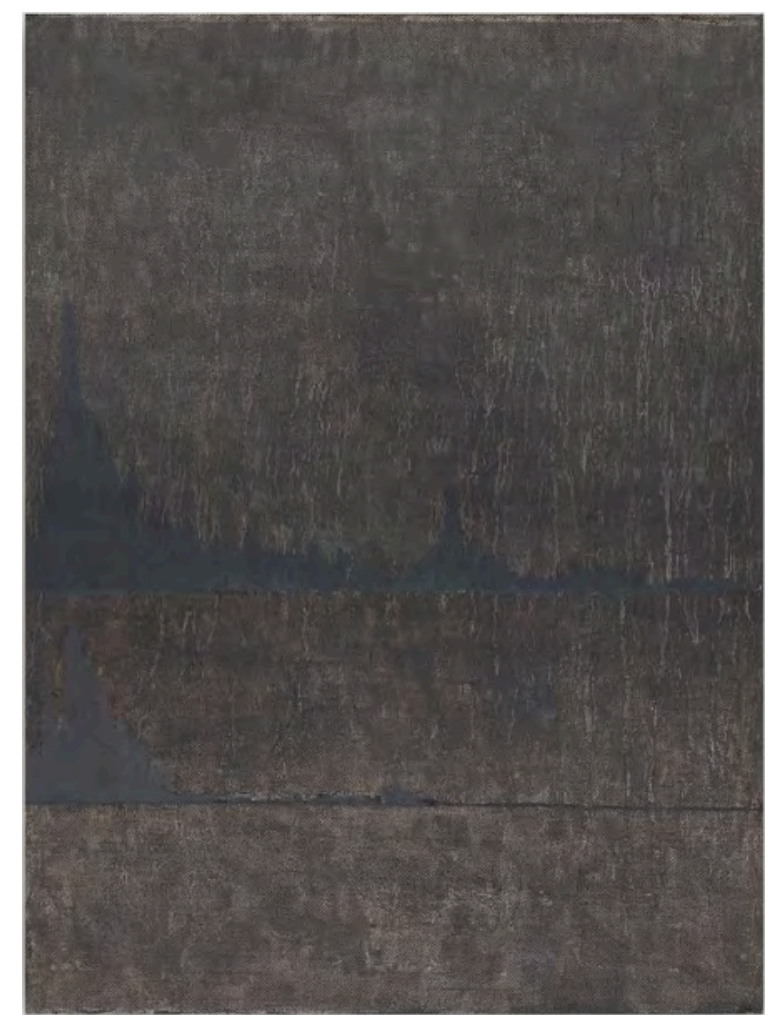

Fig. 49

Sem título, 2016

Óleo sobre tela

$40 \times 30 \mathrm{~cm}$ 


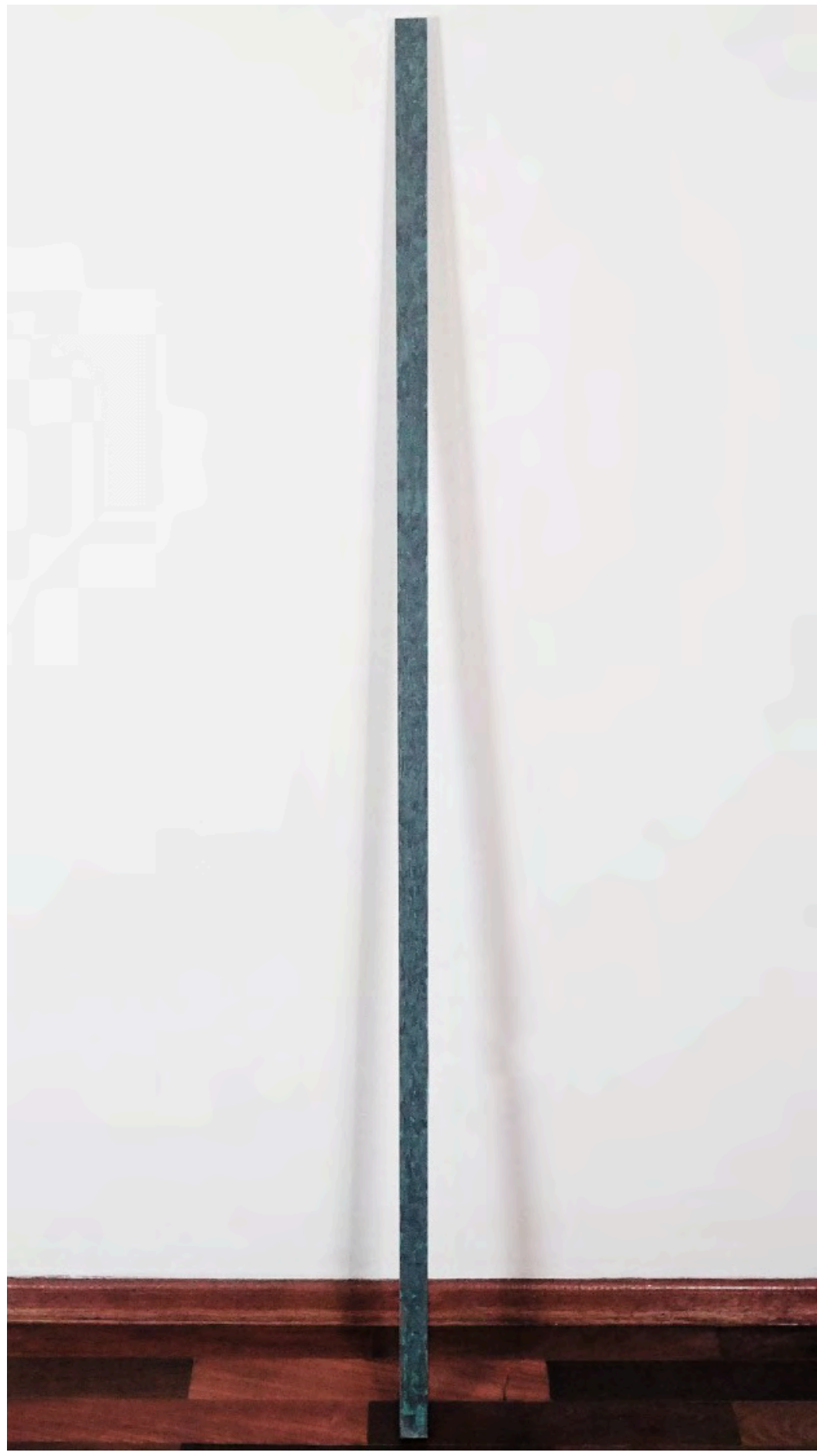

Fig. 50

Sem título, 2016 Óleo sobre ardósia $150 \times 3 \times 1,5 \mathrm{~cm}$ 


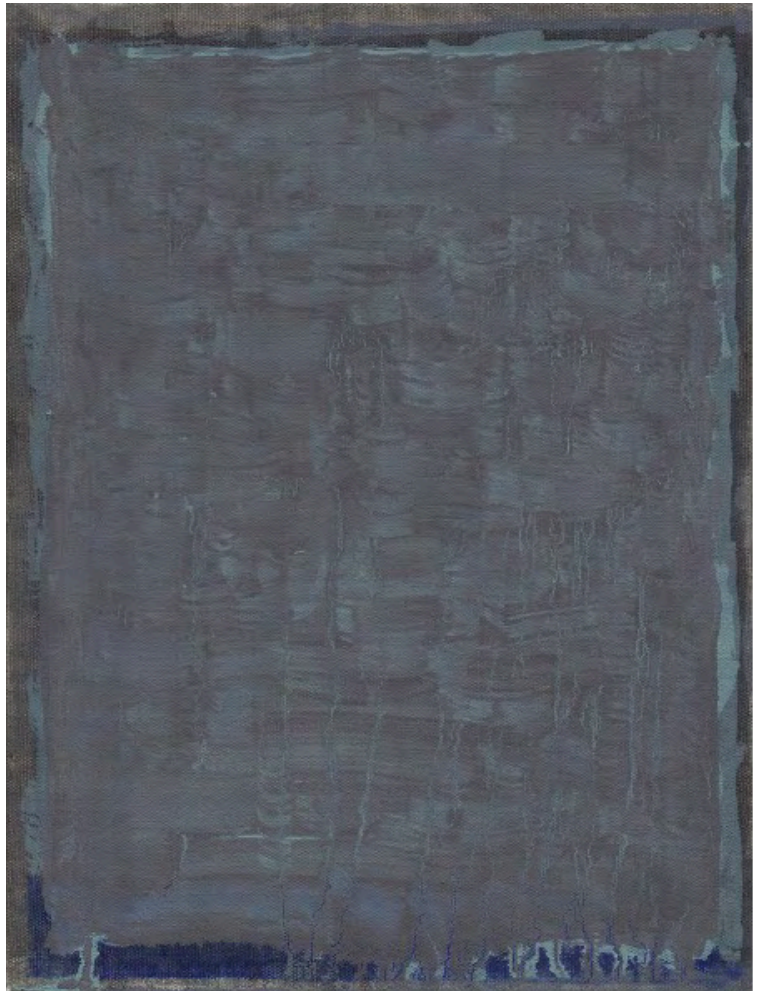

Fig. 51

Sem título, 2016

Óleo sobre tela, 25 x $18 \mathrm{~cm}$

Fig. 52

Sem título, 2016

Óleo sobre tela, $18 \times 15 \mathrm{~cm}$ 


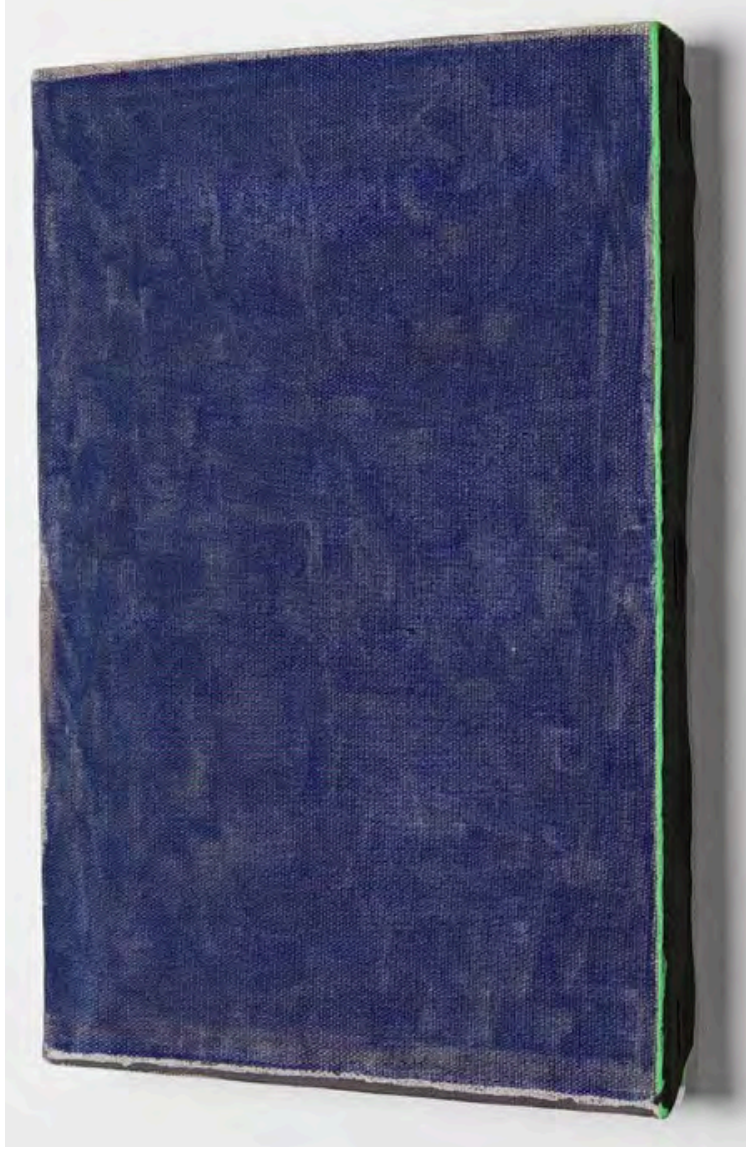

Fig. 53

Sem título, 2016

Óleo sobre tela, $20 \times 13 \mathrm{~cm}$

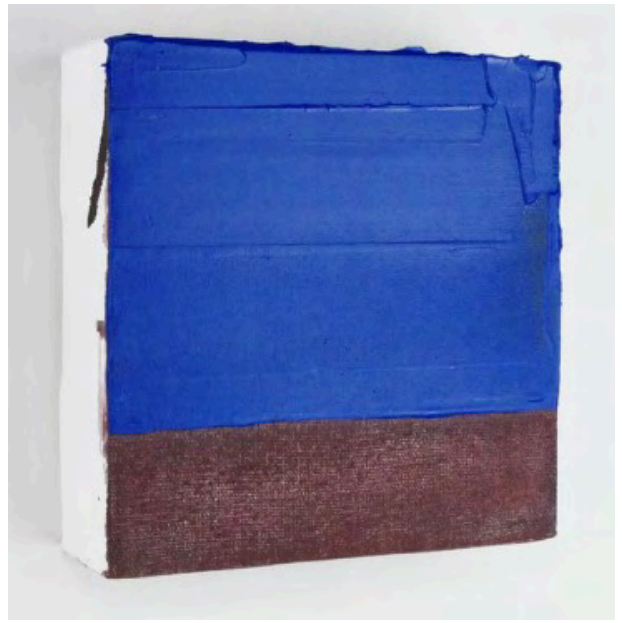

Fig. 54

Sem título, 2016

Óleo sobre tela, $10 \times 10 \times 3 \mathrm{~cm}$ 


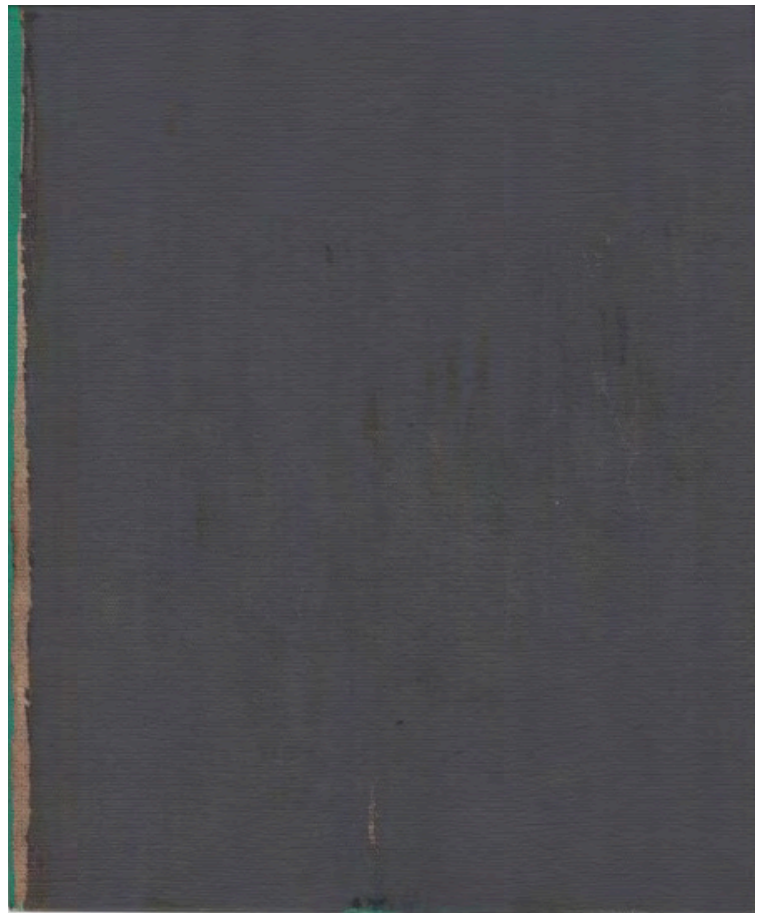

Fig. 55

Sem título, 2016

Óleo sobre tela, $18 \times 15 \mathrm{~cm}$

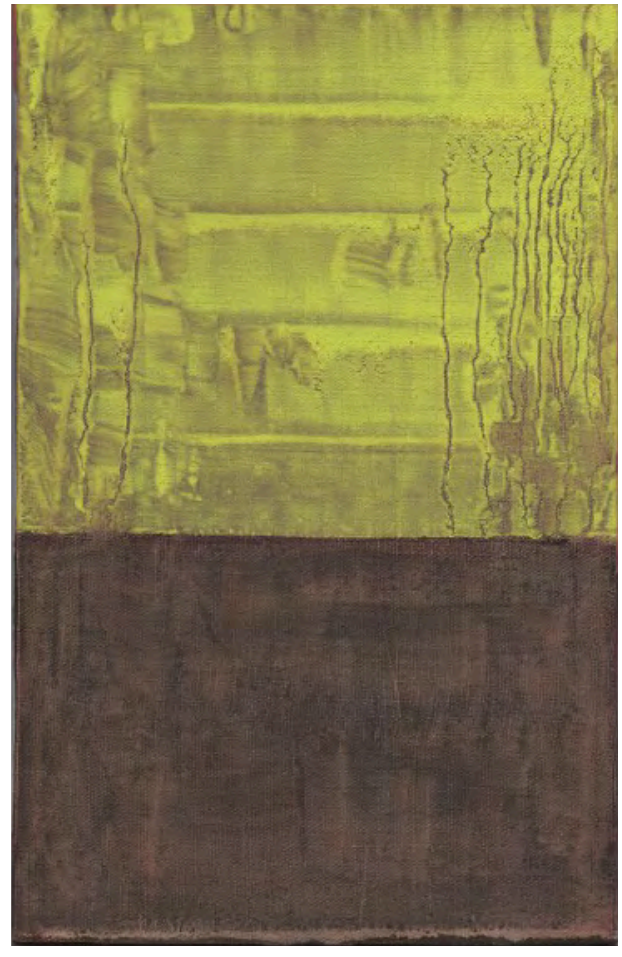

Fig. 56

Sem título, 2016

Óleo sobre tela, $20 \times 13 \mathrm{~cm}$ 


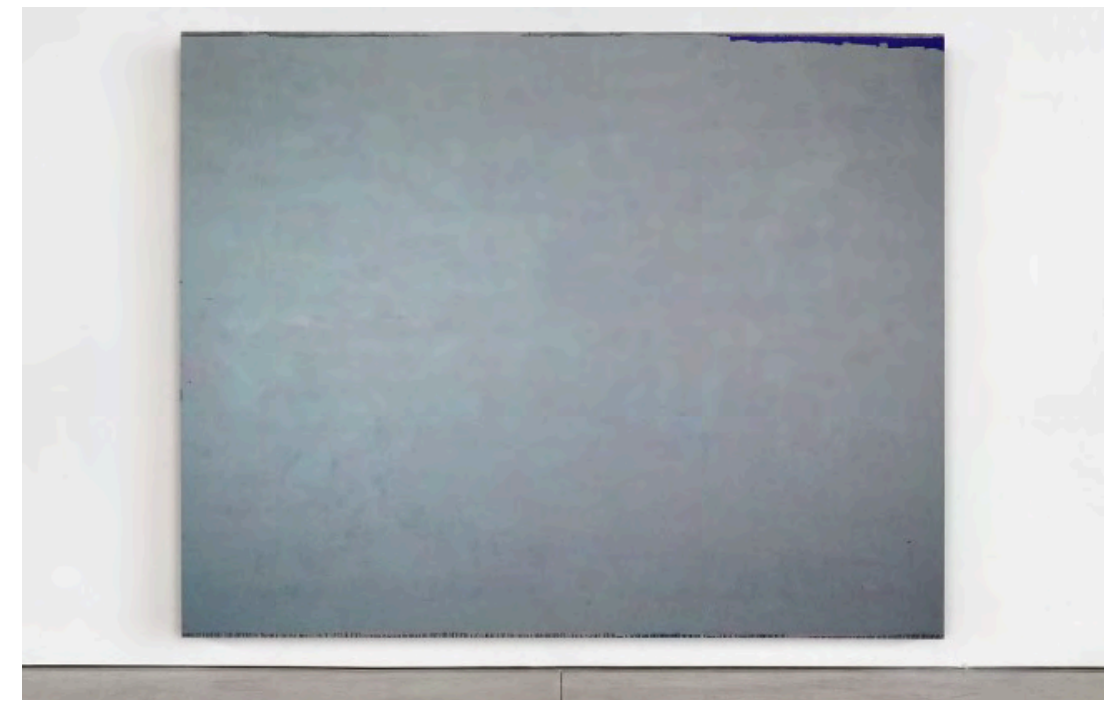

Fig. 57

Sem título, 2016

Óleo sobre tela

$230 \times 191 \mathrm{~cm}$

Fig. 58

Sem título, 2016

Óleo sobre tela

$60 \times 50 \mathrm{~cm}$ 


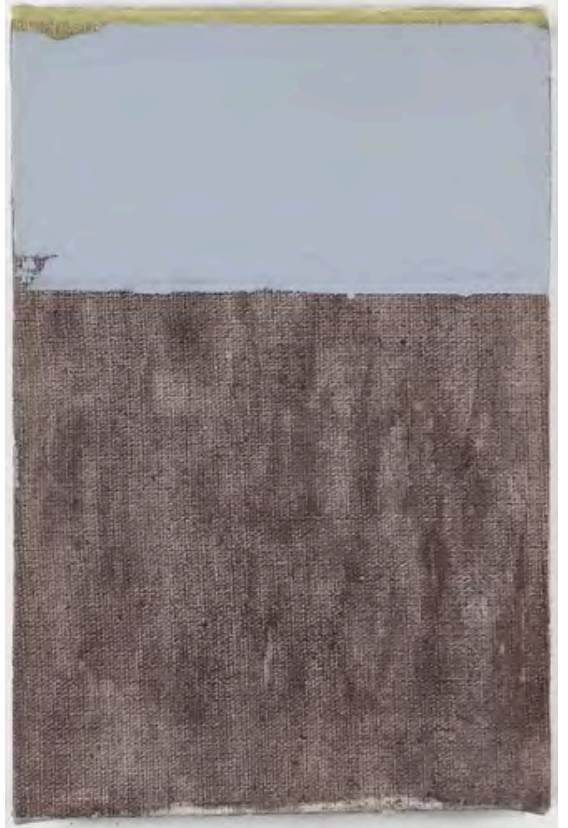

Fig. 59

Sem título, 2016

Óleo sobre tela, $15 \times 10 \mathrm{~cm}$

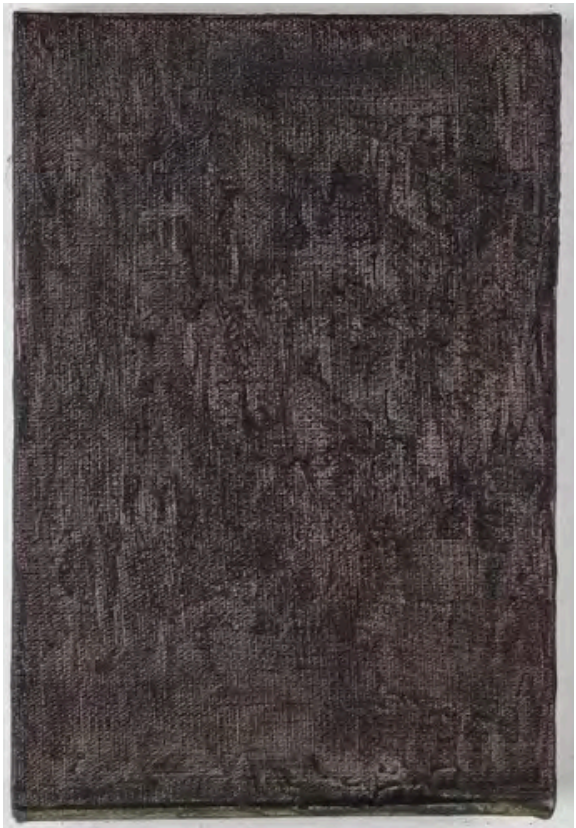

Fig. 60

Sem título, 2016

Óleo sobre tela, 15 × $10 \mathrm{~cm}$ 
Fig. 61

Sem título, 2016

Óleo sobre tela, 12 × $9 \mathrm{~cm}$

Fig. 62

Sem título, 2016

Óleo sobre tela, $10 \times 10 \mathrm{~cm}$ 
Fig. 63

Sem título, 2016

Óleo sobre tela

$22,5 \times 16,5 \mathrm{~cm}$

Fig. 64

Sem título, 2016

Óleo sobre tela

$12 \times 9 \mathrm{~cm}$ 


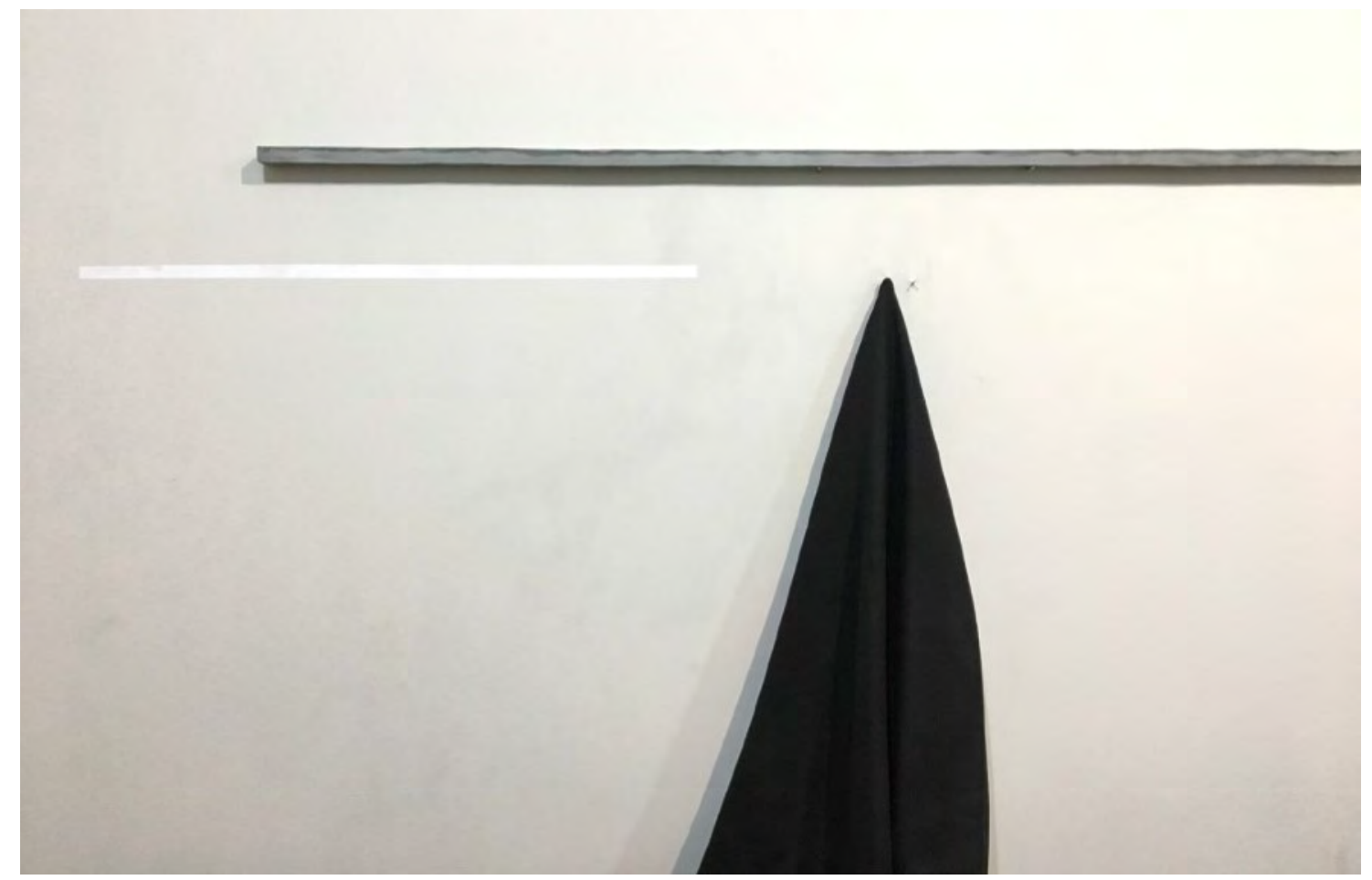

Fig. 65

Sem título, 2017

Acrílica sobre parede, ardósia e tecido de algodão, dimensões variadas 


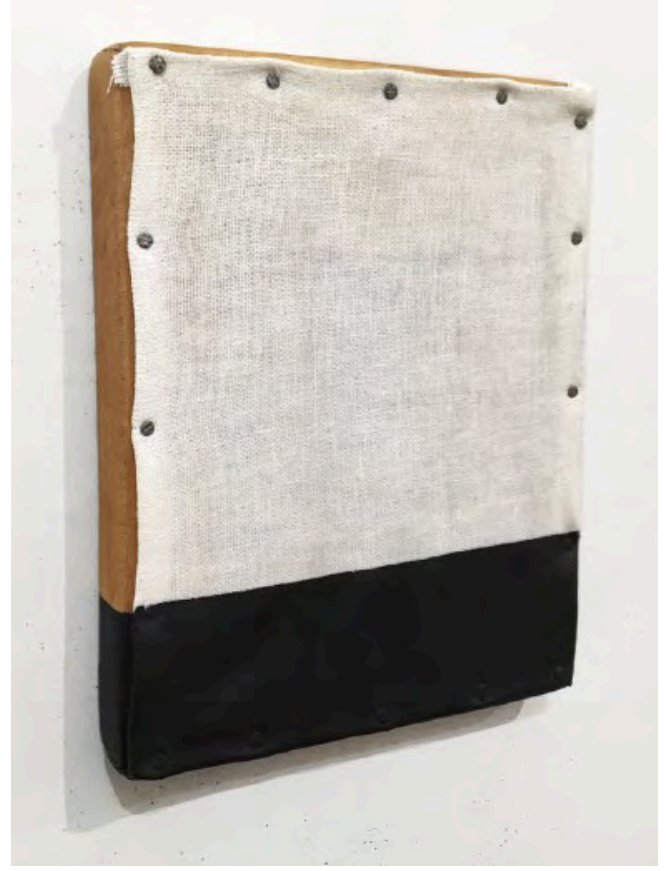

Fig. 66

Sem título, 2017

Óleo sobre linho, 14,5 x 11,5 cm

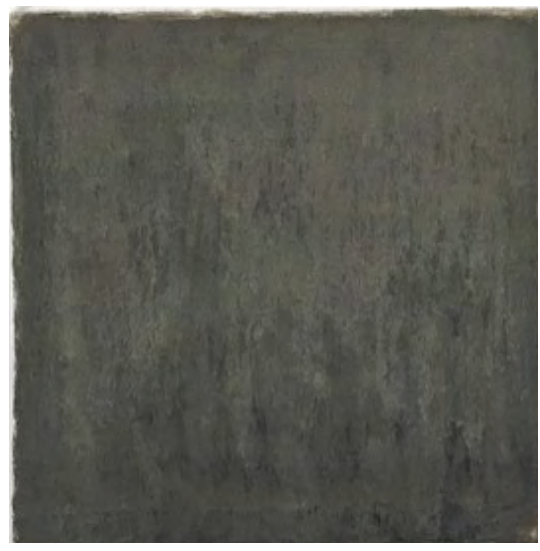

Fig. 67

Sem título, 2017

Óleo sobre tela, $15 \times 15 \mathrm{~cm}$ 


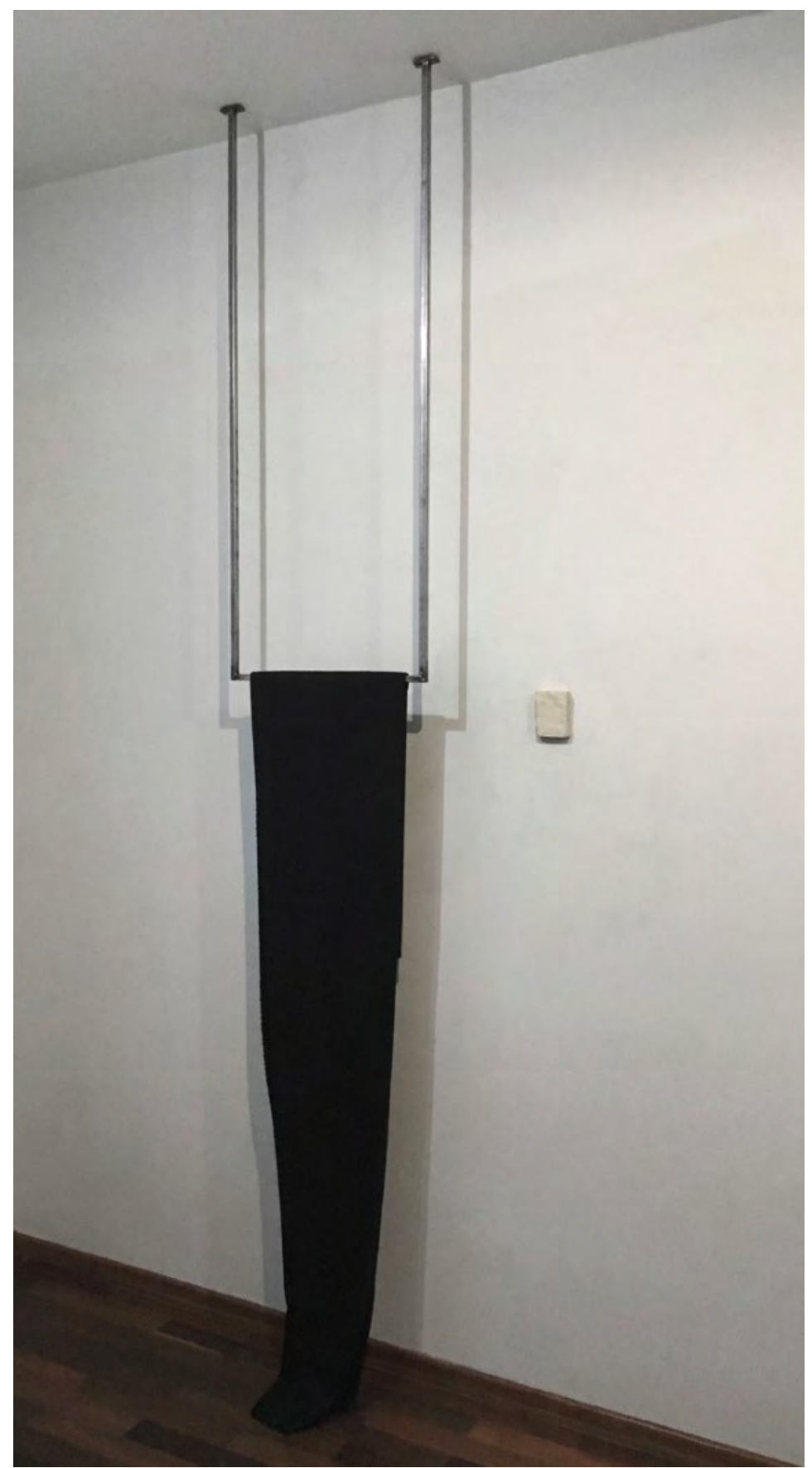

Fig. 68

Sem título, 2017

Ferro soldado,

lã e argila

dimensões variadas 


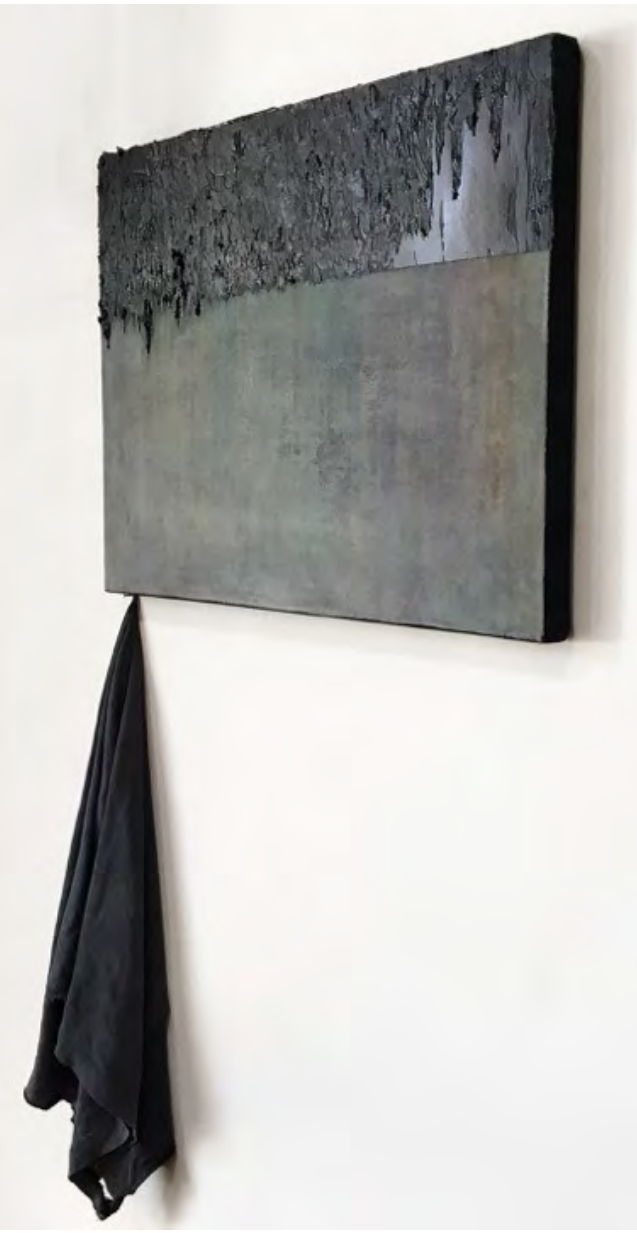

Fig. 69

Sem título, 2017

Óleo sobre linho preto e tecido de algodão preto, 75 × $40 \mathrm{~cm}$ 


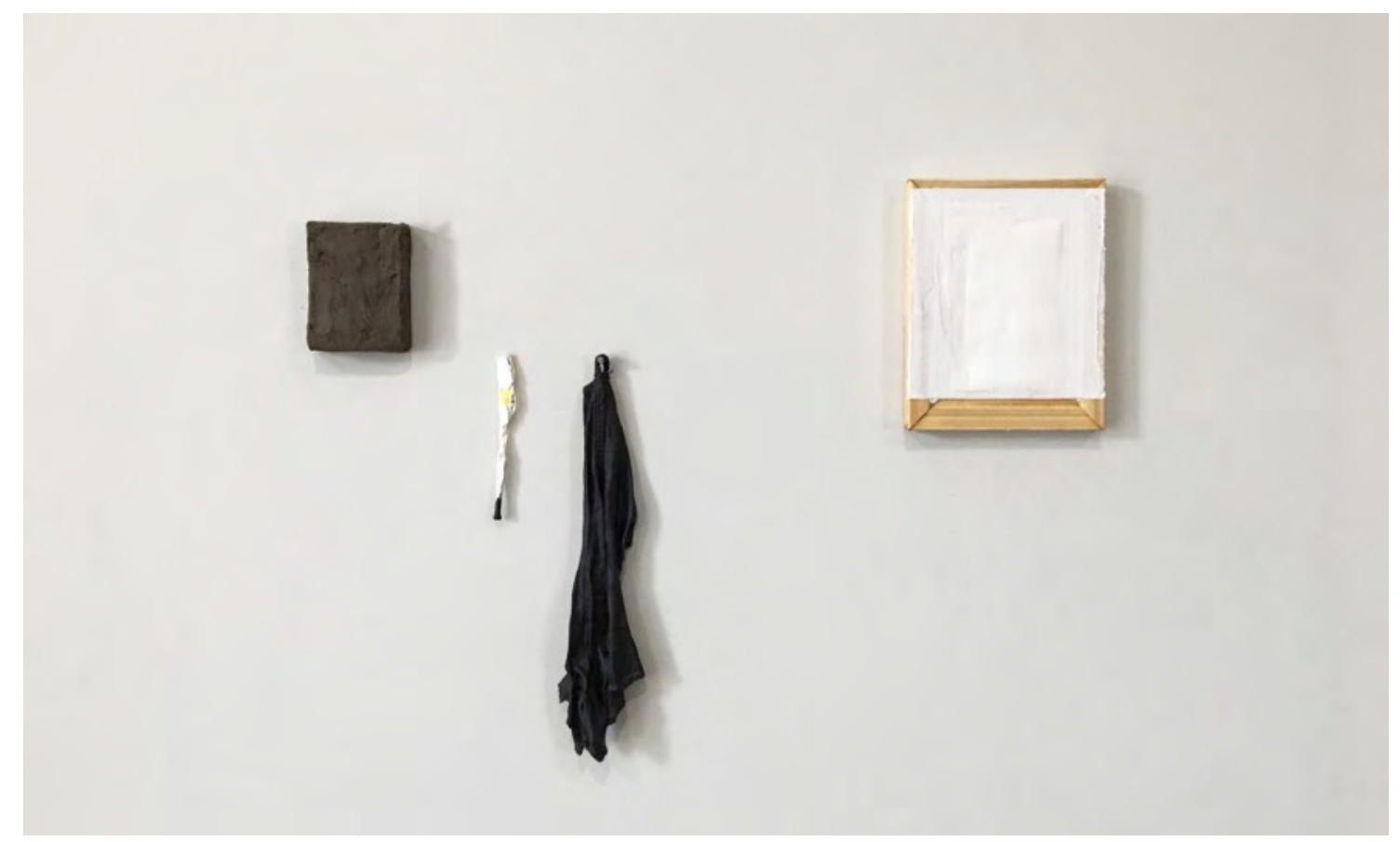

Fig. 70

Sem título, 2017

Argila, acrílica em tecido de algodão, prego coberto de fita crepe, gesso e chassi de madeira $36 \times 38 \mathrm{~cm}$ 


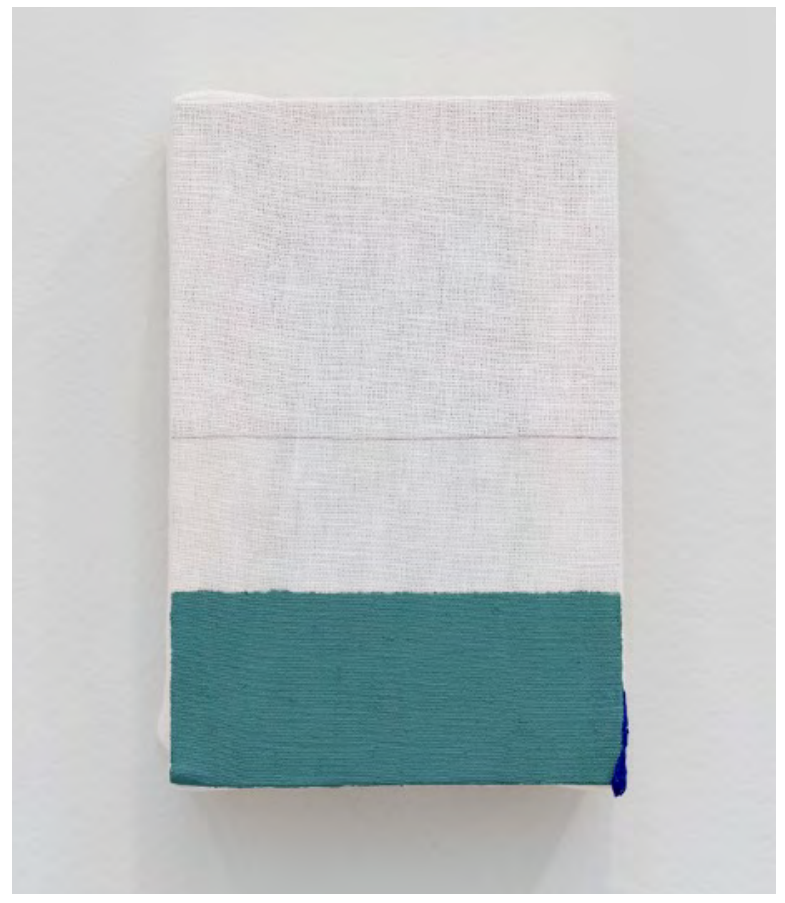

Fig. 71

Sem título, 2017

Óleo e lapis sobre tela $15,5 \times 10 \times 3 \mathrm{~cm}$

Fig. 72

Sem título, 2017

Óleo sobre tela, 12 × $9 \mathrm{~cm}$ 


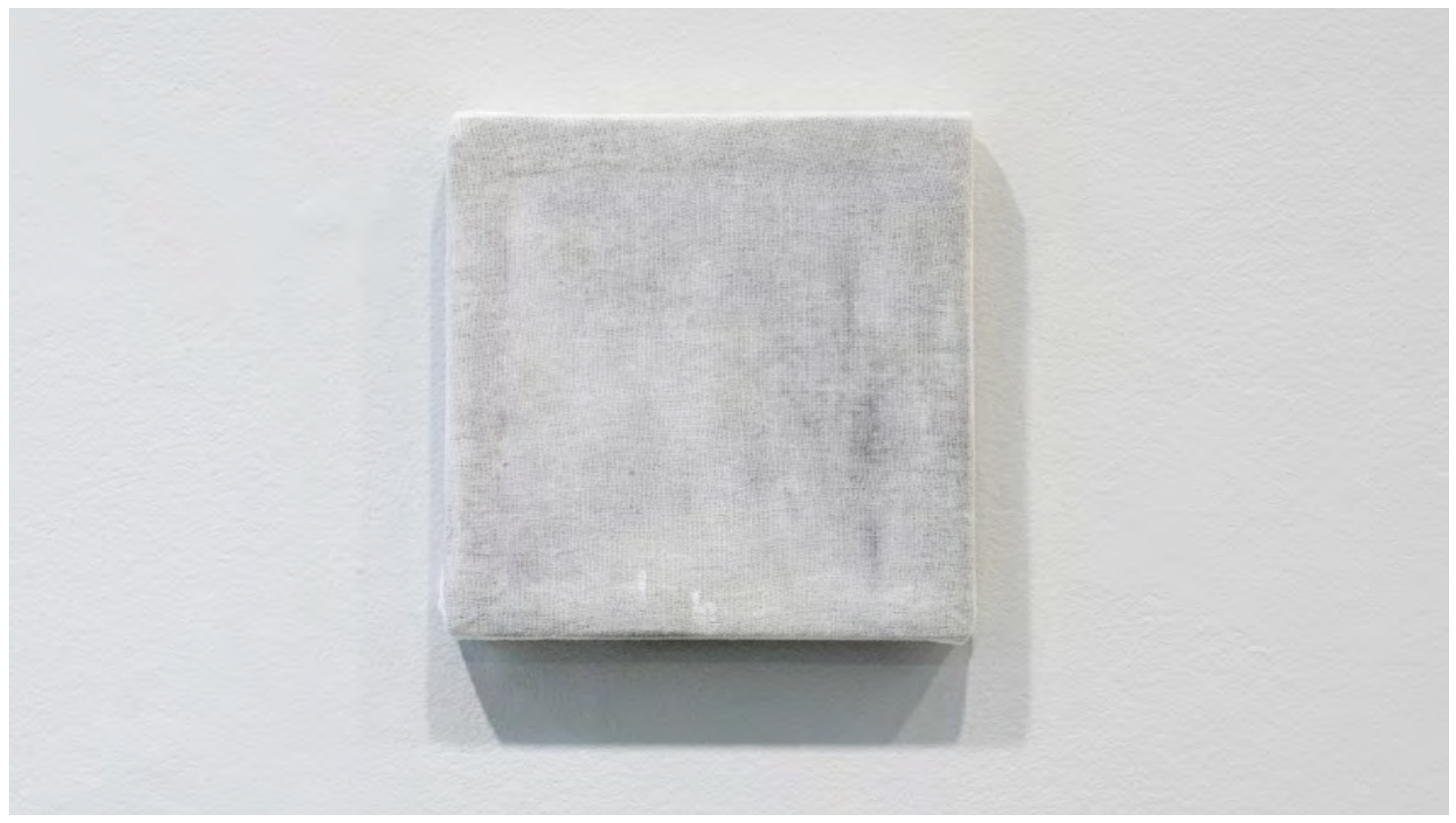

Fig. 73

Sem título, 2017

Óleo e lapis sobre tela, $15 \times 15 \mathrm{~cm}$

Fig. 74

Sem título, 2017

Acrílica sobre tela $40 \times 30 \mathrm{~cm}$ 
Fig. 75

Sem título, 2017

Tecidos mergulhados

em acrílica

$140 \times 3 \mathrm{~cm}$ 
Fig. 76

Sem título, 2017

Chapa de compensado e acrílica sobre tecido

dimensões variada

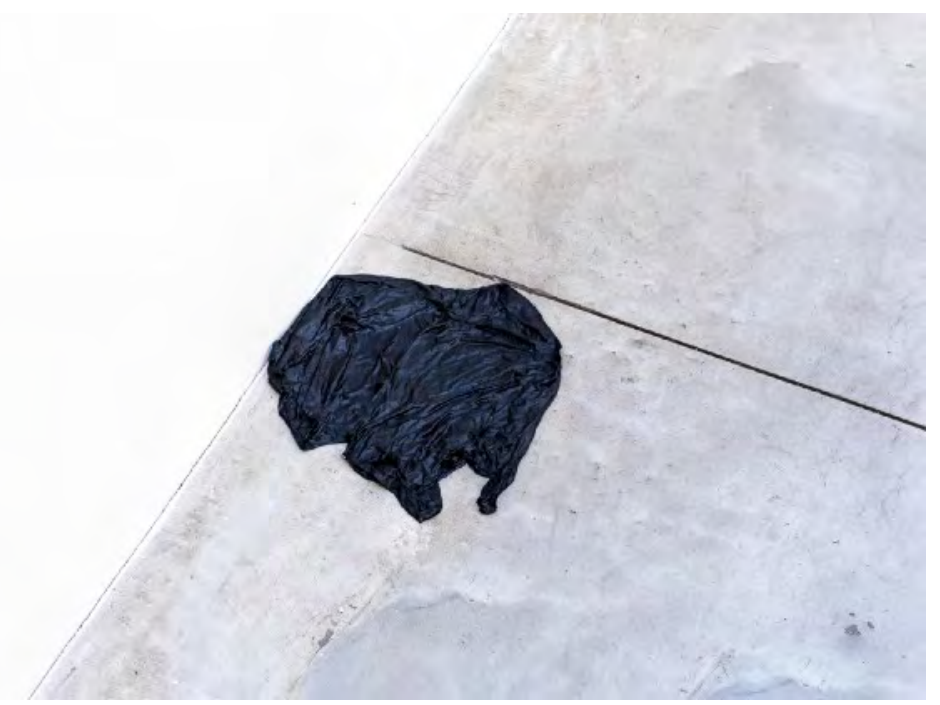

Fig. 77

(detalhe fig. 76) 


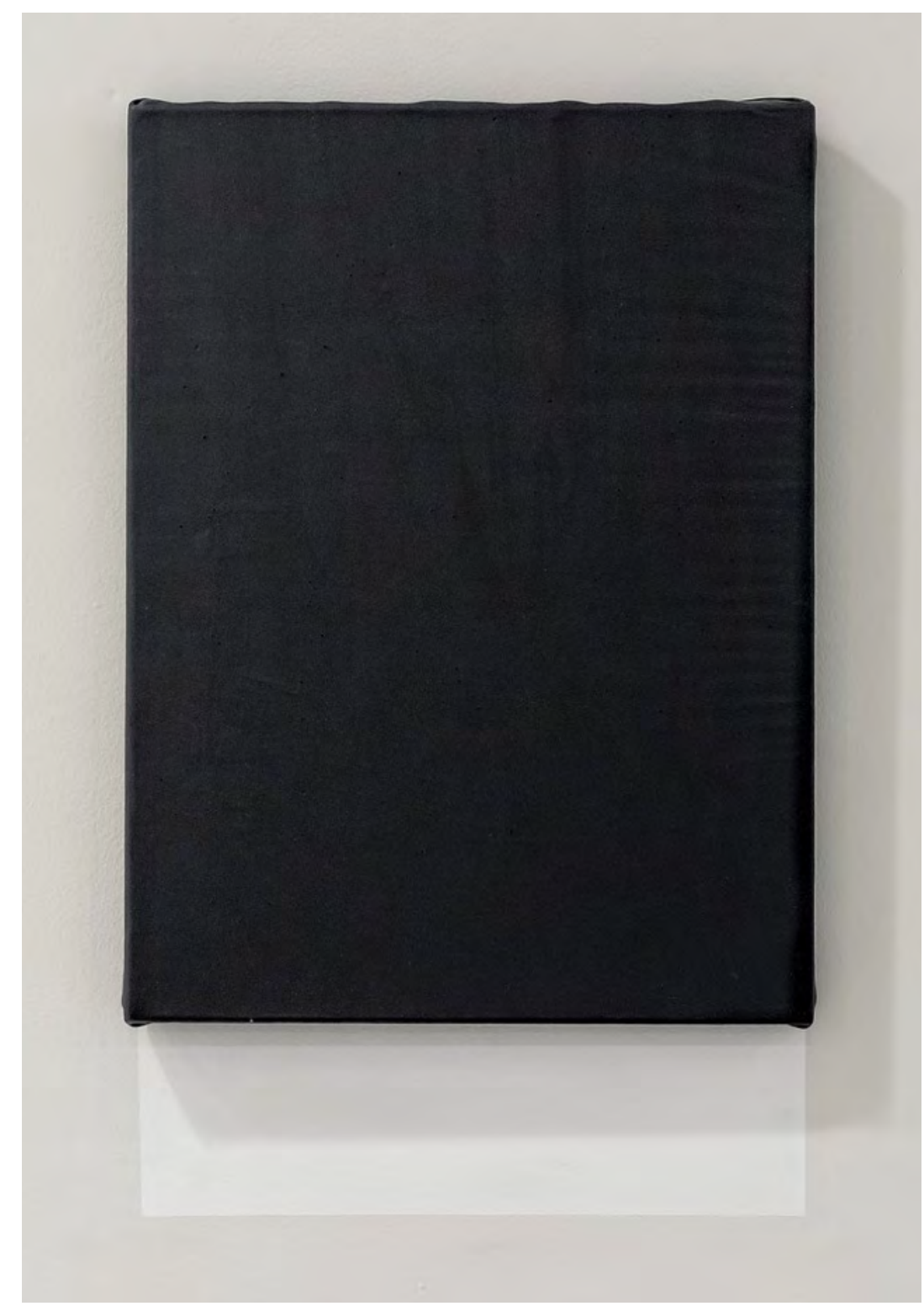

Fig. 78

Luz pintada, 2017 Acrílica sobre tela e parede $40 \times 30 \mathrm{~cm}$ 


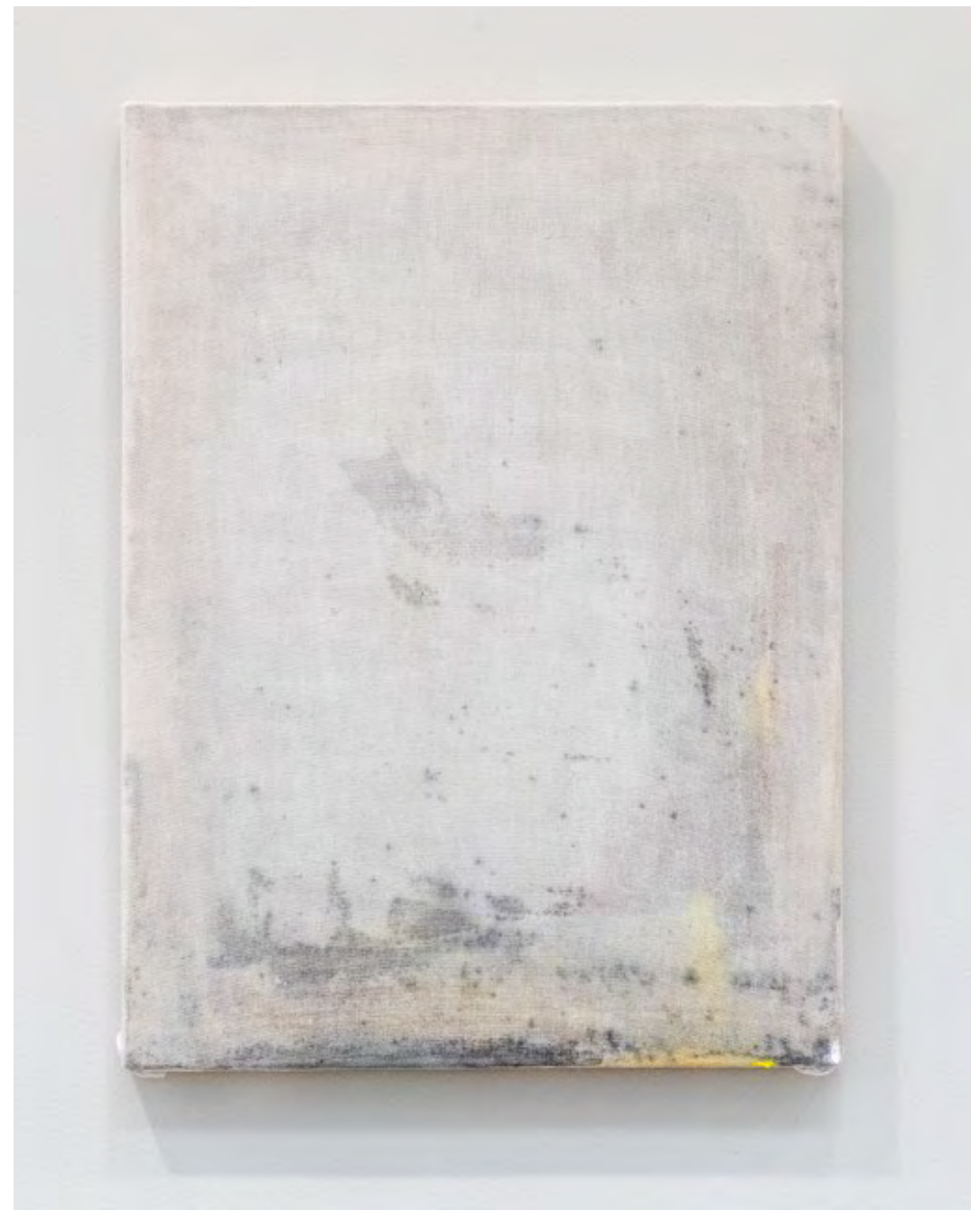

Fig. 79

Sem título, 2017 óleo sobre tela $40 \times 30 \mathrm{~cm}$ 
Fig. 80

Sem título, 2017

Argila

$5,5 \times 3,5 \mathrm{~cm}$
Fig. 81

Sem título, 2017

Óleo sobre tela e tecido de algodão $15,5 \times 10 \times 3 \mathrm{~cm}$ 
Fig. 82

Sem título, 2017

base transparente sobre tela e acrílica sobre parede $100 \times 70 \mathrm{~cm}$

Fig. 83

Sombra pintada, 2017 Madeira e acrílica sobre parede $100 \times 5 \times 15 \mathrm{~cm}$ 


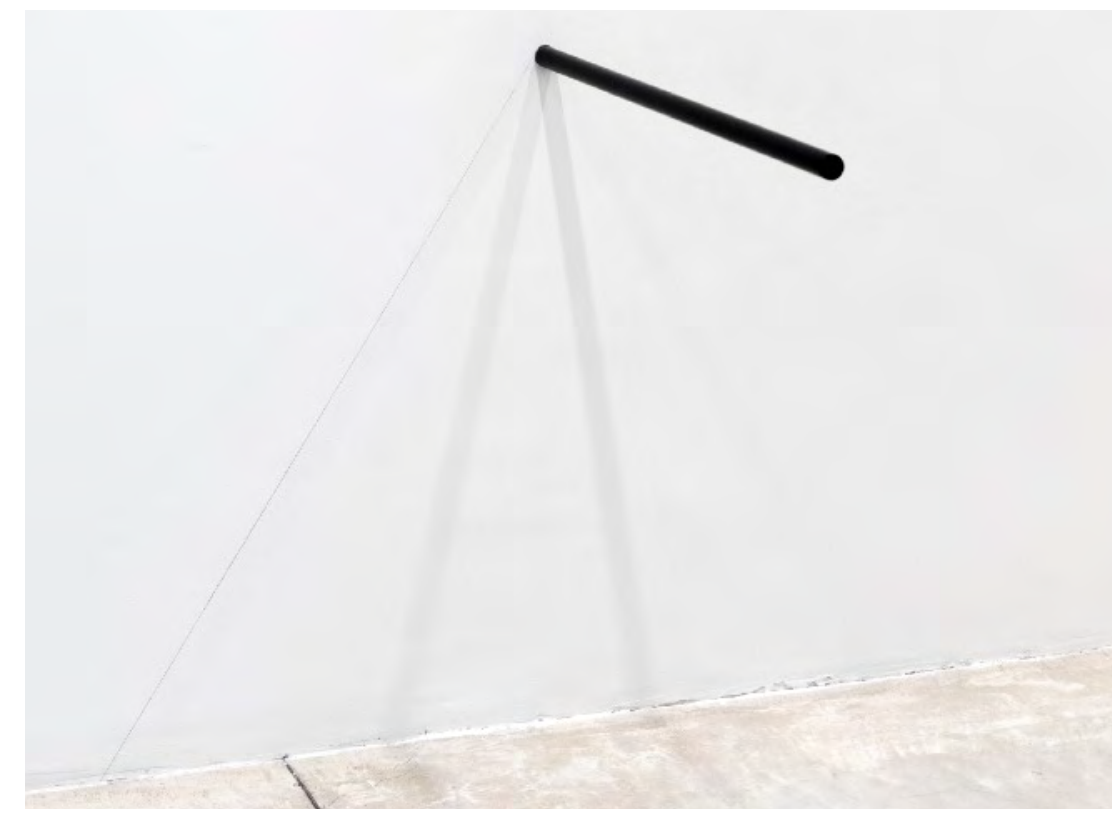

Fig. 84

Sombra marcada, 2017

Barra de ferro e grafite sobre parede $70 \times 2,5 \mathrm{~cm}$

Fig. 85

Sem título, 2017

Argila e acrílica em tecido de algodão dimensões variadas 
Fig. 86

Paisagem

Fantasma, 2018

Encáustica sobre lycra crua

$14 \times 10 \mathrm{~cm}$

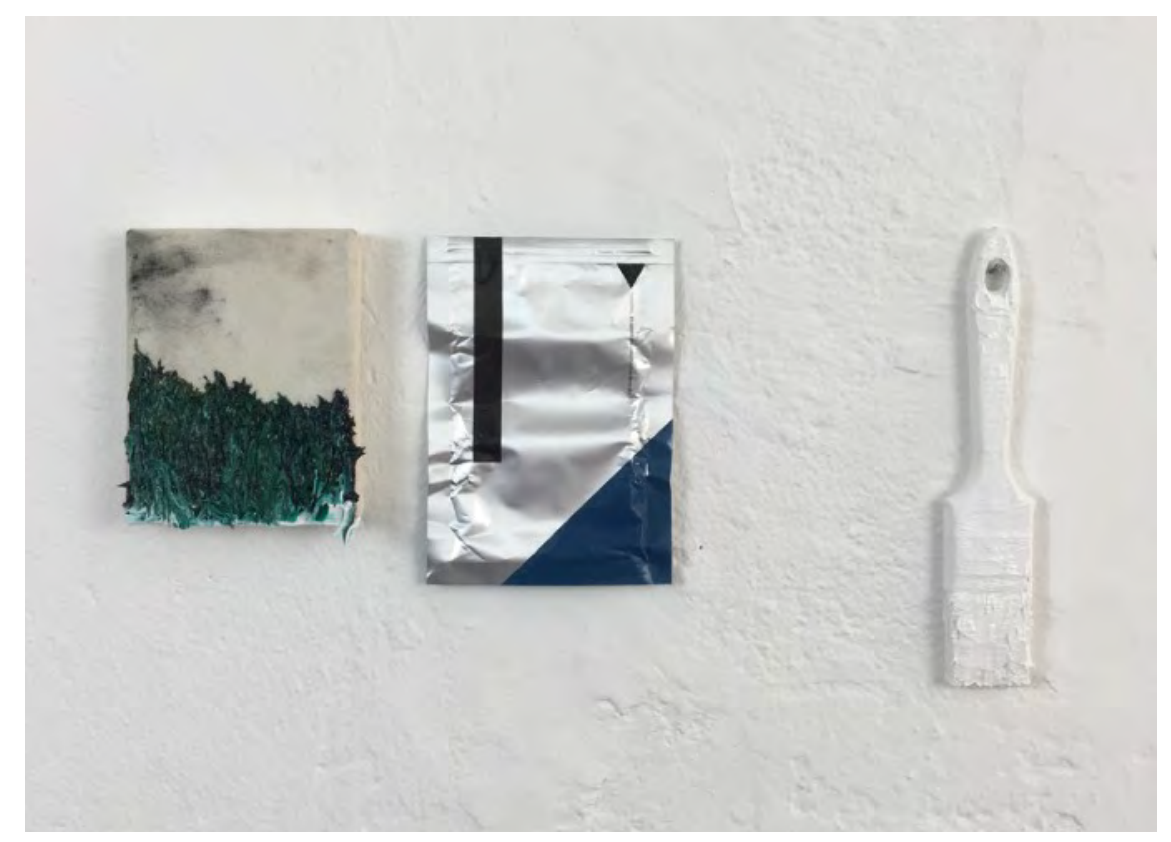

Fig. 87

Sem título, 2018 Óleo sobre tela, embalagem e pincel $15 \times 40 \mathrm{~cm}$ 


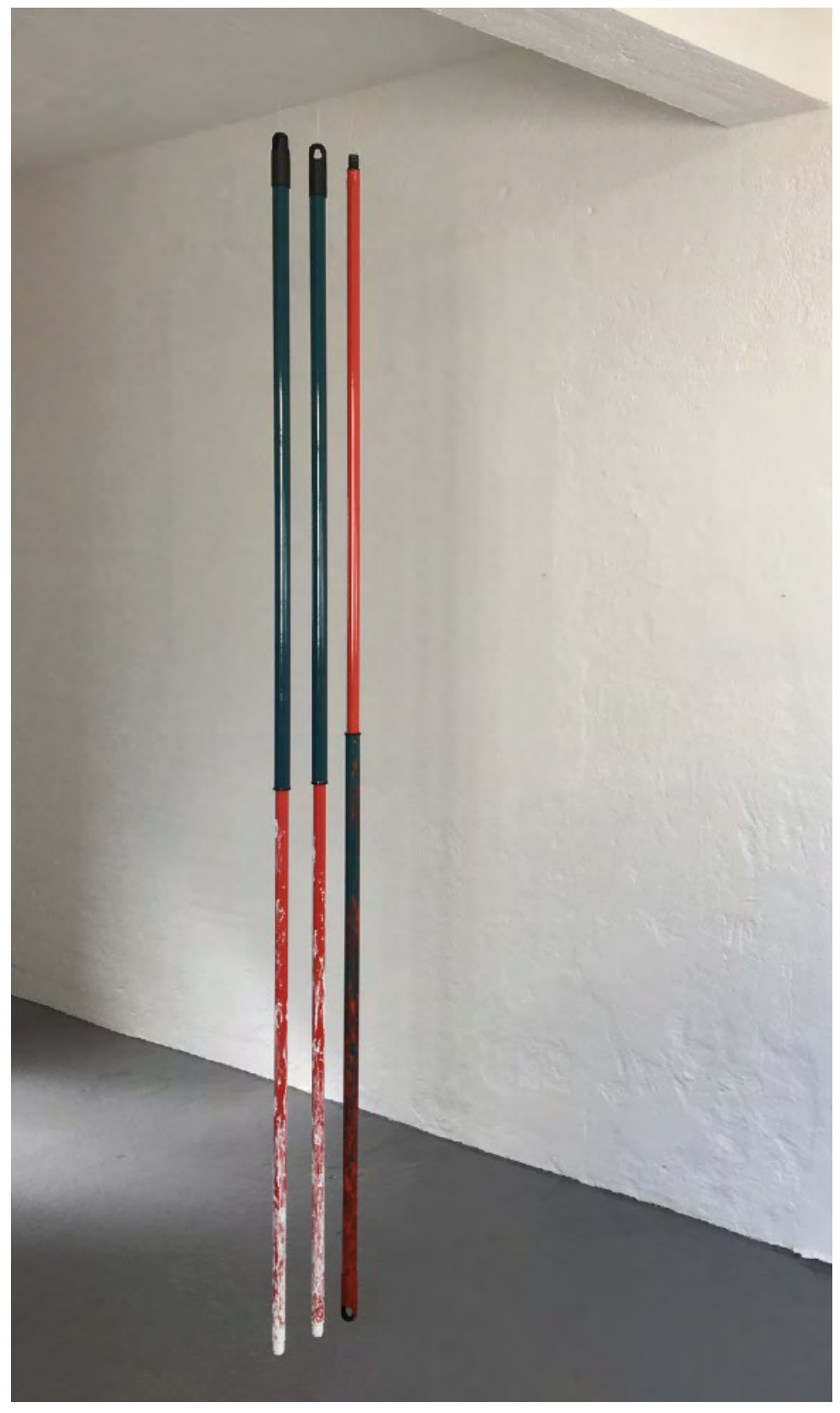

Fig. 88

Cabos, 2018

Óleo sobre extensor de pintura

$200 \times 24 \times 2 \mathrm{~cm}$ 

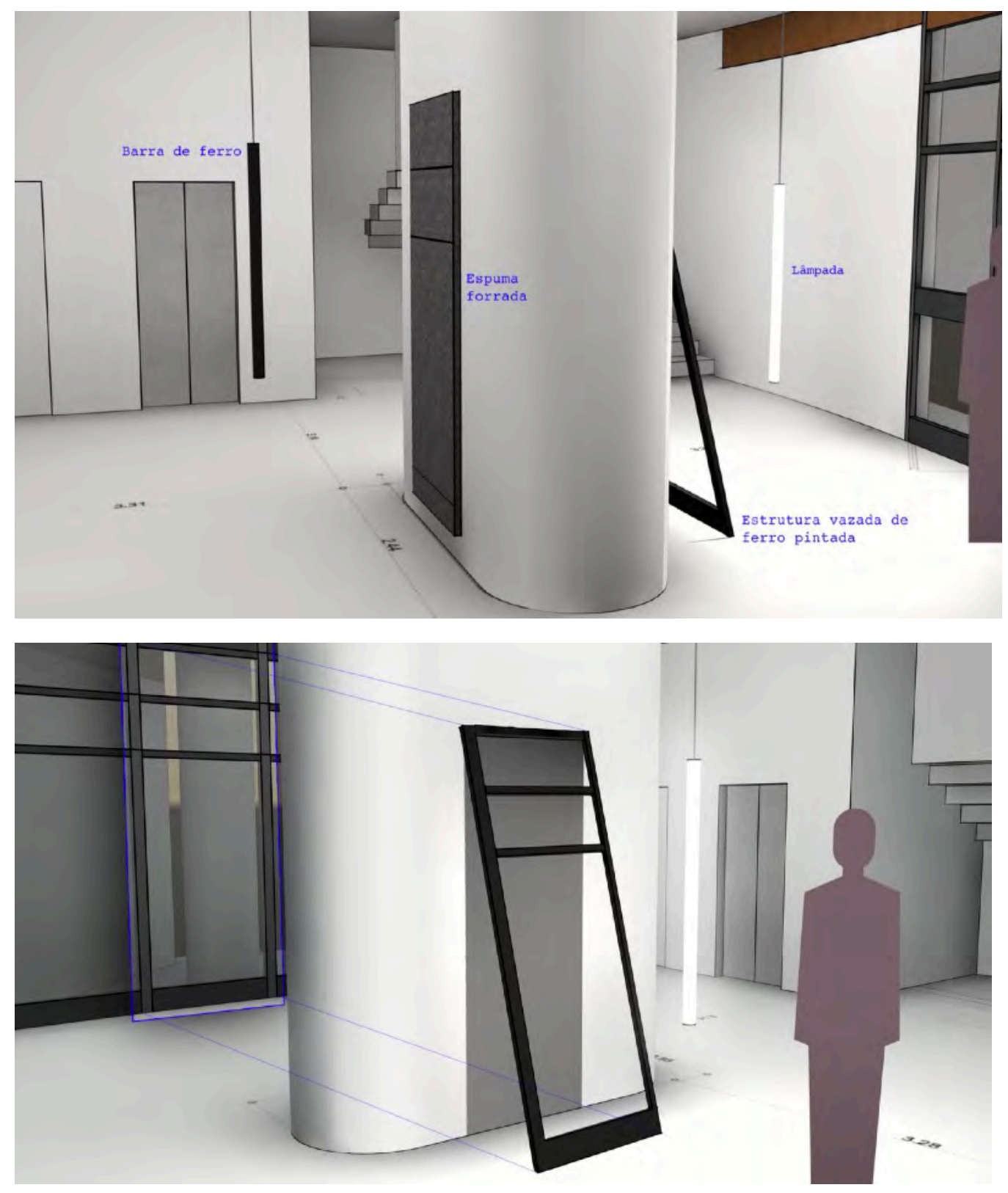

Figs. 89 e 90

Simulações, 2017

Espuma forrada, estrutura de ferro, lâmpada e barra de ferro, dimensões variadas (projeto não realizado) 

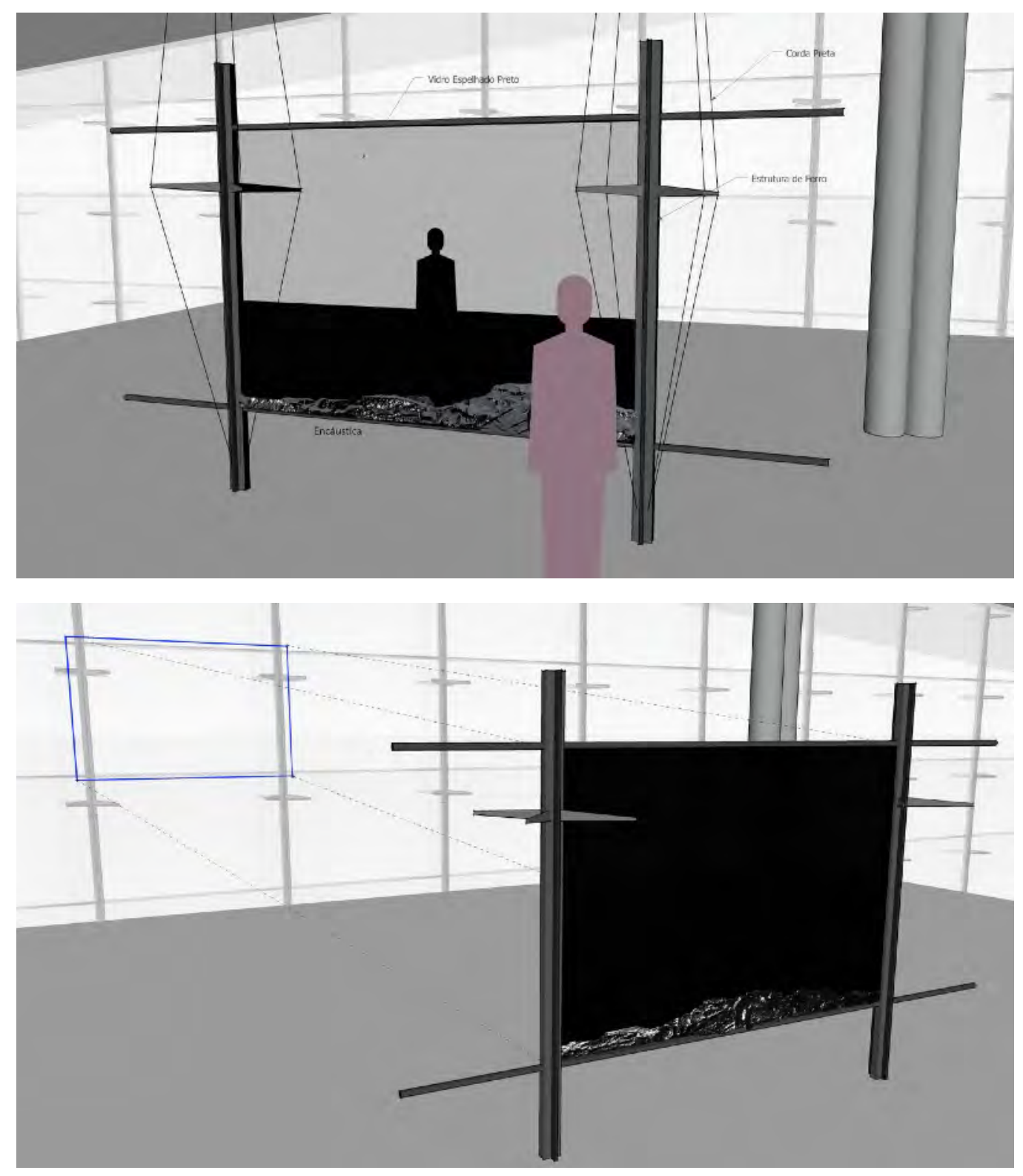

Figs. 91 e 92

Janela Rasa, 2018

Ferro, vidro e encáustica

(projeto não realizado) 

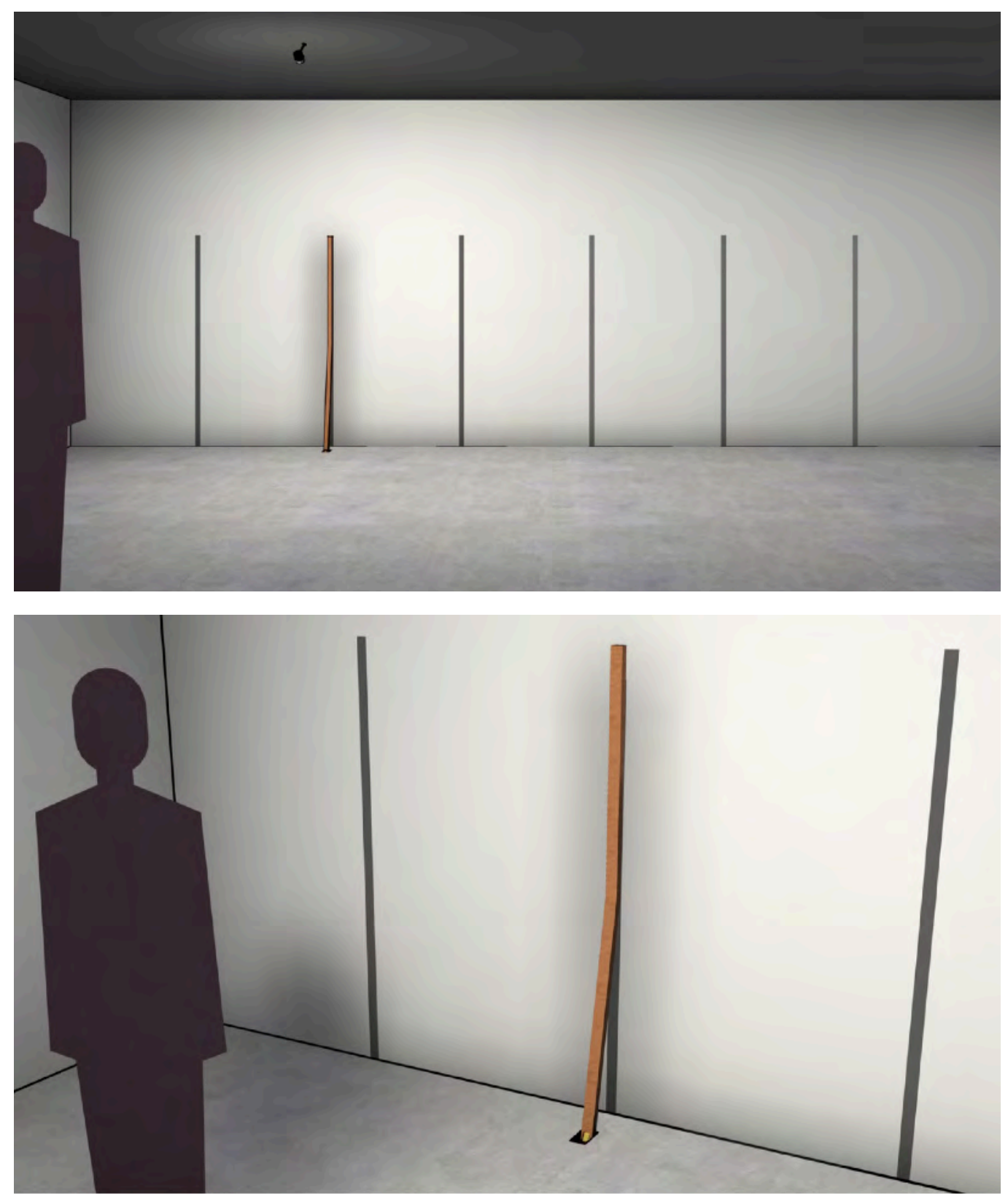

Figs. 93 e 94

Matéria e Corpo, 2018

Tinta sobre parede, madeira e ouro (projeto não realizado) 

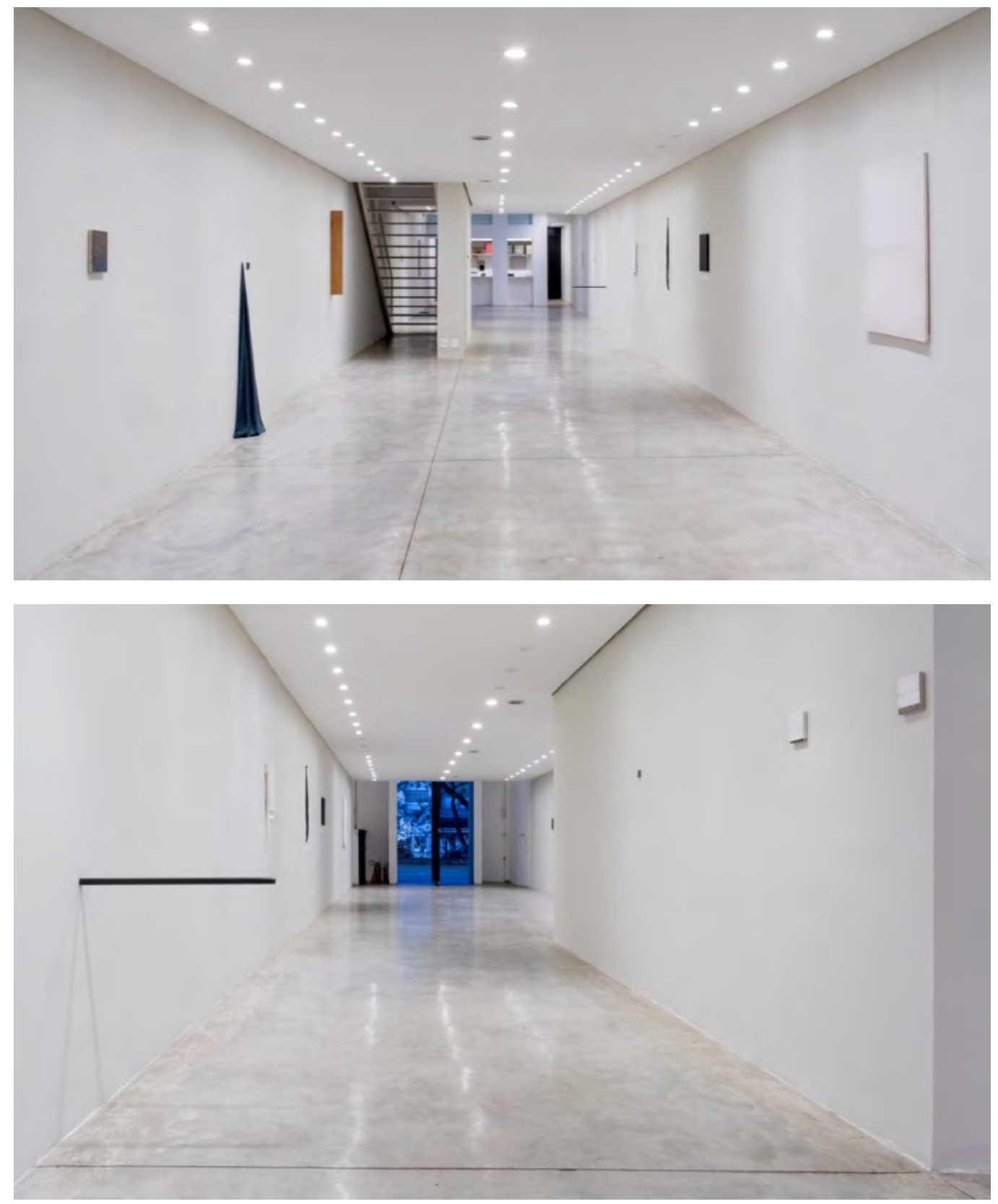

Figs. 95 e 96

Vista geral da exposição individual Apagamento, 2017

Galeria Sancovsky, São Paulo 

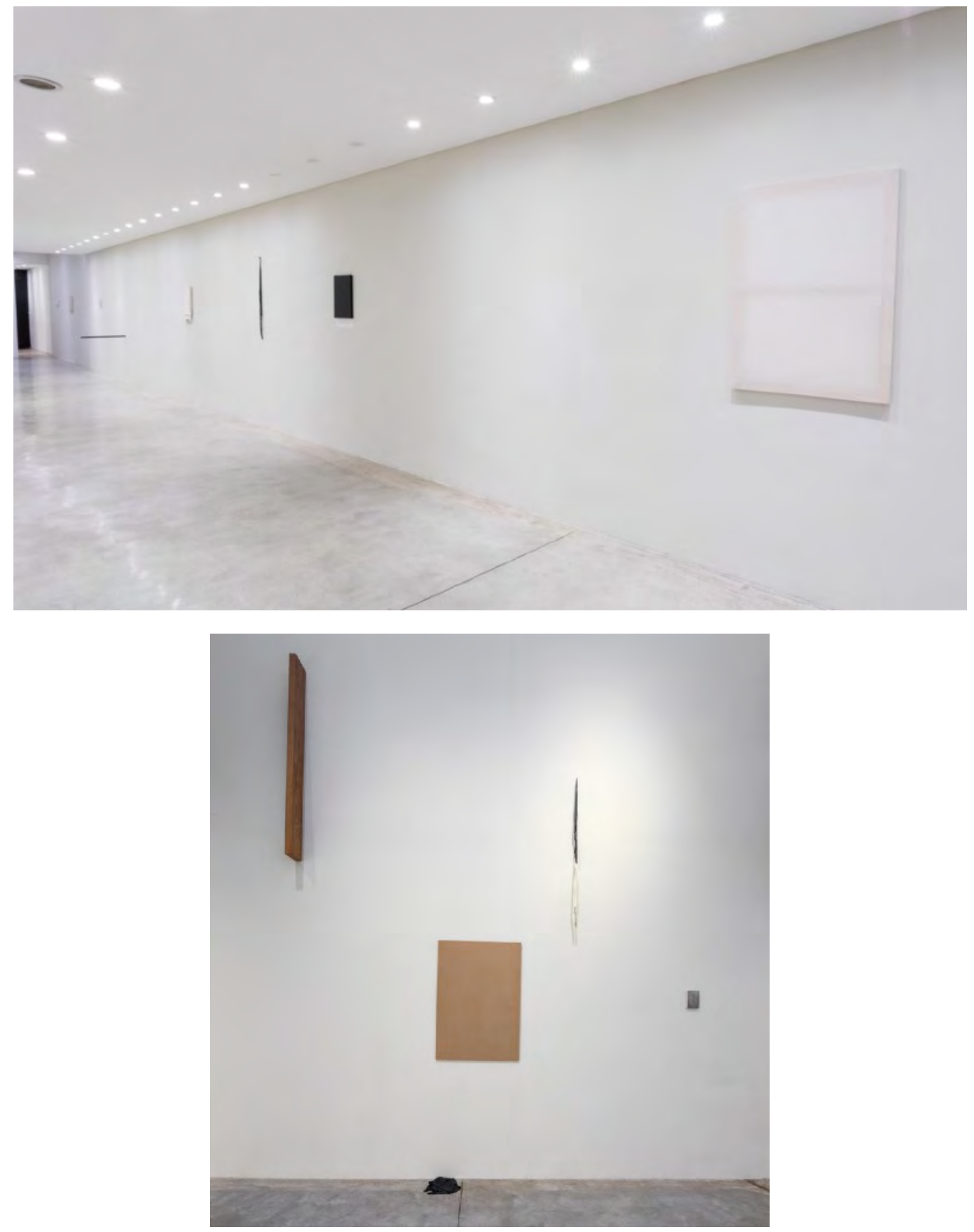

Figs. 97 e 98

Vista geral da exposição individual Apagamento, 2017 Galeria Sancovsky, São Paulo 


\section{Considerações finais}

A tentativa de buscar pressupostos comuns aos trabalhos se mostrou proveitosa, geradora de reflexões reveladoras e fundamentais, trazendo à tona pontos sensíveis das obras abordadas. Mas ficou também evidente a dificuldade de definir uma grande narrativa acerca do trabalho: é aparente a incapacidade de cada uma dessas ideias centrais discutidas (sombra, luz, espaço, matérias e corpo) darem conta de toda a complexidade que caracteriza os trabalhos. Por isso, outros caminhos e possibilidades para refletir a obra estão em aberto.

A pintura foi o ponto de partida para a maioria das obras, mesmo naqueles trabalhos em que aparentava não fazer parte, como, por exemplo, em Flutuações, onde as escolhas das cores das luzes, do formato do espelho e das relações de sombras e luzes no espaço, de modo não declarado, devem muito às pinturas. Essa prática artística parece ficar, desse modo, no trânsito das linguagens, sem, com isso, rejeitar sua origem na pintura.

A ideia inicial de desenvolver uma pesquisa mais extensa sobre algumas das referências artísticas apontadas no texto (conforme os capítulos propostos no projeto da dissertação a respeito dos artistas Robert Ryman e Armando Reverón) foi superada. Ficou claro que essas e outras referências deveriam entrar no texto como parte do raciocínio do trabalho - subordinadas a ele. Afinal, uma reflexão mais alongada tiraria o foco dos trabalhos e não deixaria clara a discussão estabelecida.

Não houve também a intenção de consolidar um discurso privilegiado da obra, mas sim de estabelecer reflexões e ideias que possam se desdobrar - quando oportuno - para outros caminhos e direções. Por isso, o interesse foi em elaborar um texto de contornos mais abrangentes, buscando, ao máximo, não tornar os trabalhos reféns de uma visão estrita; até porque, como nos lembra o filósofo e crítico de arte francês DidiHuberman: "as obras traem com frequência os discursos"34.

Assim, esse exercício de reflexão pode terminar mantendo-se aberto e inconclusivo como forma de preservar a potência latente dessa prática artística que segue.

\footnotetext{
${ }^{34}$ DIDI-HUBERMAN, op. cit., p.76.
} 


\section{Referências}

ARCHER, Michael. Arte Contemporânea. Trad. Alexandre Krug e Valter Ellis Siqueira. São Paulo: Martins Fontes, 2008.

BACHELARD, Gaston. A poética do espaço. Trad. Antônio da Costa Leal e Lídia do Valle Santos Leal. São Paulo: Martins Fontes, 1989.

BAUDRILLARD, Jean. Simulacros e Simulação. Lisboa: Relógio d’Água Editores, 1991.

BOIS, Yve-Alain. A Pintura como modelo. Trad. Fernando Santos. São Paulo: Martins Fontes, 2009.

CHIPP, Herschel B. Teorias da arte moderna. Colaboração de Peter Selz, Joshua C. Taylor. 2. ed (2a tiragem). São Paulo: Martins Fontes, 1999.

DANTO, Arthur. Após o fim da arte. A arte contemporânea e os limites da história. Trad. Saulo Krieger. São Paulo: Odysseus Editora, 2006.

DIDI-HUBERMAN, Georges. Diante da imagem: questão colocada aos fins de uma história da arte. Trad. Paulo Neves. São Paulo Editora 34, 2013.

Paulo Editora 34, 2010.

O que vemos, o que nos olha. Trad. Paulo Neves. São

DIEGUES, Isabel (org.). Pintura brasileira século XXI. Colaboração de Frederico Coelho e Renato Rezende. Rio de Janeiro: Cobogó, 2011.

FERREIRA, Glória. Escritos de artistas: anos 60/70. Rio de Janeiro: Jorge Zahar, 2009.

FLUSSER, Vilém. Filosofia da Caixa Preta: Ensaios para uma futura filosofia da fotografia. Rio de Janeiro: Relume Dumará, 2002.

FOSTER, Hal. O retorno do real. São Paulo: Cosac Naify, 2014.

GAGE, John. A cor na arte. Trad. Jefferson Luiz Camargo. São Paulo: Martins Fontes, 2012.

GINZBURG, Jaime. Cegueira e literatura. São Paulo: Aletria, 2004.

GREENBERG, Clement. Arte e Cultura. Trad. Otacílio Nunes. São Paulo: Cosac Naify, 2013.

GODFREY, Tony. Painting Today. Nova York: Phaidon, 2009.

GOLDBERG, Roselee. A arte da Performance - Do Futurismo ao Presente. Trad.: Jeferson Luiz Camargo. São Paulo: Martins Fontes, 2006. 
LICHTENSTEIN, Jacqueline (dir.). A pintura: textos essenciais. v1 a v10. Colaboração de Jean François Groulier, Nadeije Laneyrie-Dagen e Denys Riout. São Paulo: Ed. 34, 2004.

KRAUSS, Rosalind. A escultura no campo ampliado. Trad. Elizabeth Carbone Baez. Rio de Janeiro, 1984.

Martins Fontes, 2007.

Caminhos da escultura moderna. Trad. Julio Fisher. São Paulo:

MAMMÌ, Lorenzo. Volpi. São Paulo: Cosac Naify, 1999.

Letras, 2012.

O que resta: arte e crítica de arte. São Paulo: Companhia das

MERLEAU-PONTY, Maurice. Fenomenologia da Percepção. Trad. Carlos Alberto Ribeiro de Moura. São Paulo: Martins Fontes, 1999.

O olho e o espírito. Trad. Paulo Neves Maria Ermantina

Galvão Gomes Pereira. São Paulo: Cosac Naify, 2004.

MONTEIRO, Paulo. Paulo Monteiro. São Paulo: Cosac Naify, Pinacoteca do Estado, 2009.

NAVES, Rodrigo. A Forma Difícil - Ensaios Sobre Arte brasileira. São Paulo: Editora Ática, 1996.

PASTA, Paulo. Educação pela pintura. São Paulo: Martins Fontes, 2012.

ROSENBERG, Harold. Objeto ansioso. São Paulo: Cosac Naify, 2004.

RUSCH, Michael. Novas mídias na arte contemporânea. Trad. Cássia Maria Nasser. São Paulo: Martins Fontes, 2006.

SCHOPENHAUER, Arthur. Sobre a Visão e as Cores. Trad. Erlon José Paschoal. São Paulo: Nova Alexandria, 2003.

STEINBERG, Leo. Outros critérios. Trad. Célia Euvaldo. São Paulo: Cosac Naify, 2008.

STORR, Robert. John Zurier: Paintings 1981 - 2014. Nova York: Peter Blum Edition, 2015.

SYLVESTER, David. Sobre arte moderna. Trad. Alexandre Morales. São Paulo: Cosac Naify, 2007.

TASSINARI, Alberto. O espaço moderno. São Paulo: Cosac Naify, 2001. 


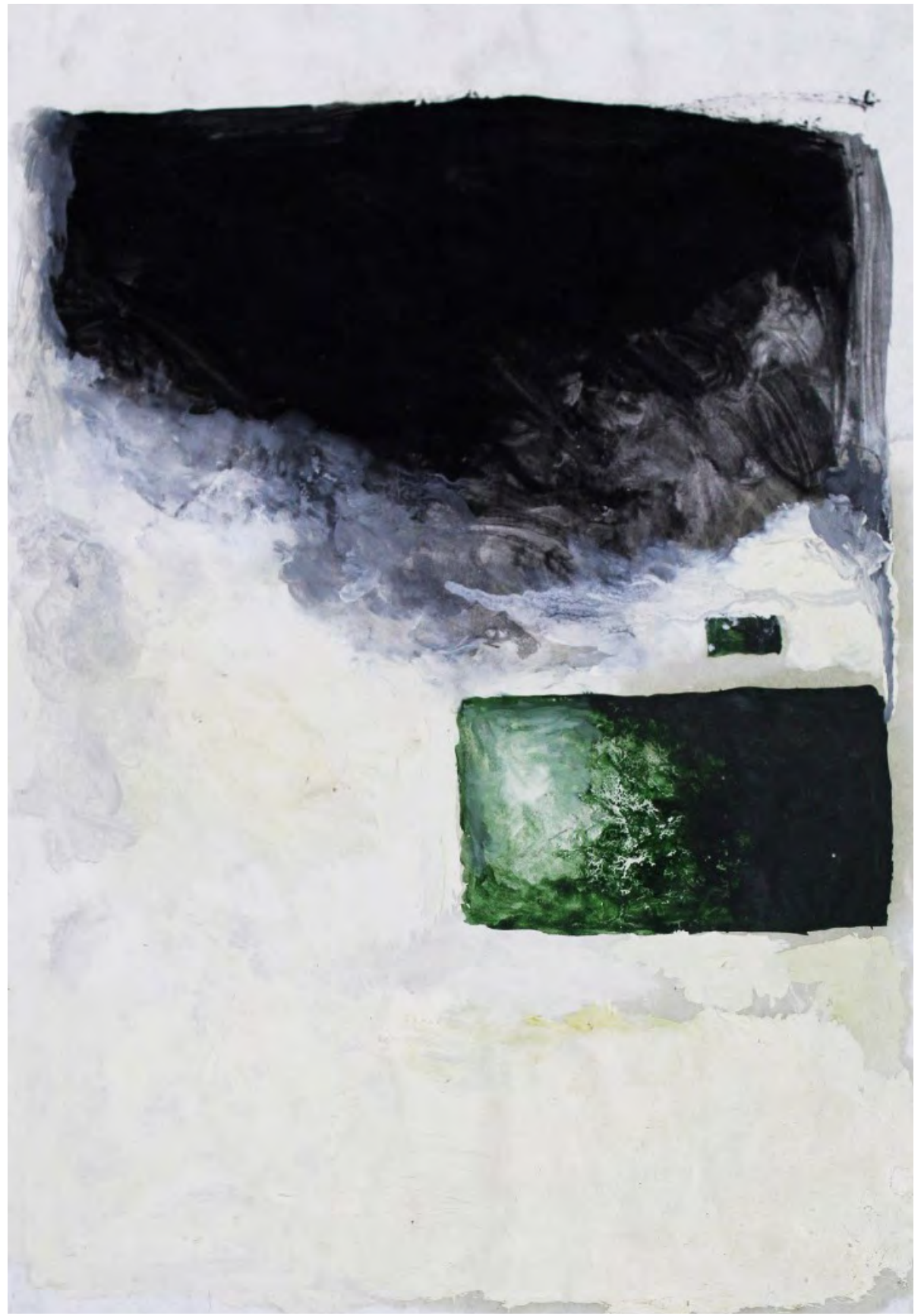

Sem título, 2011

Óleo sobre papel

$29 \times 42 \mathrm{~cm}$ 